\title{
National Assessment of Shoreline Change: Historical Shoreline Change Along the Pacific Northwest Coast
}

Gpensile Report 2012-1007

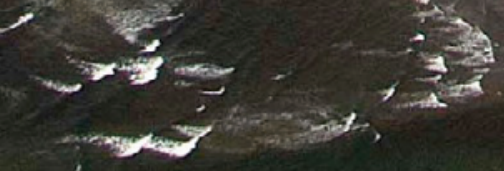

U.S. Department of the Interior U.S, Geological Survey

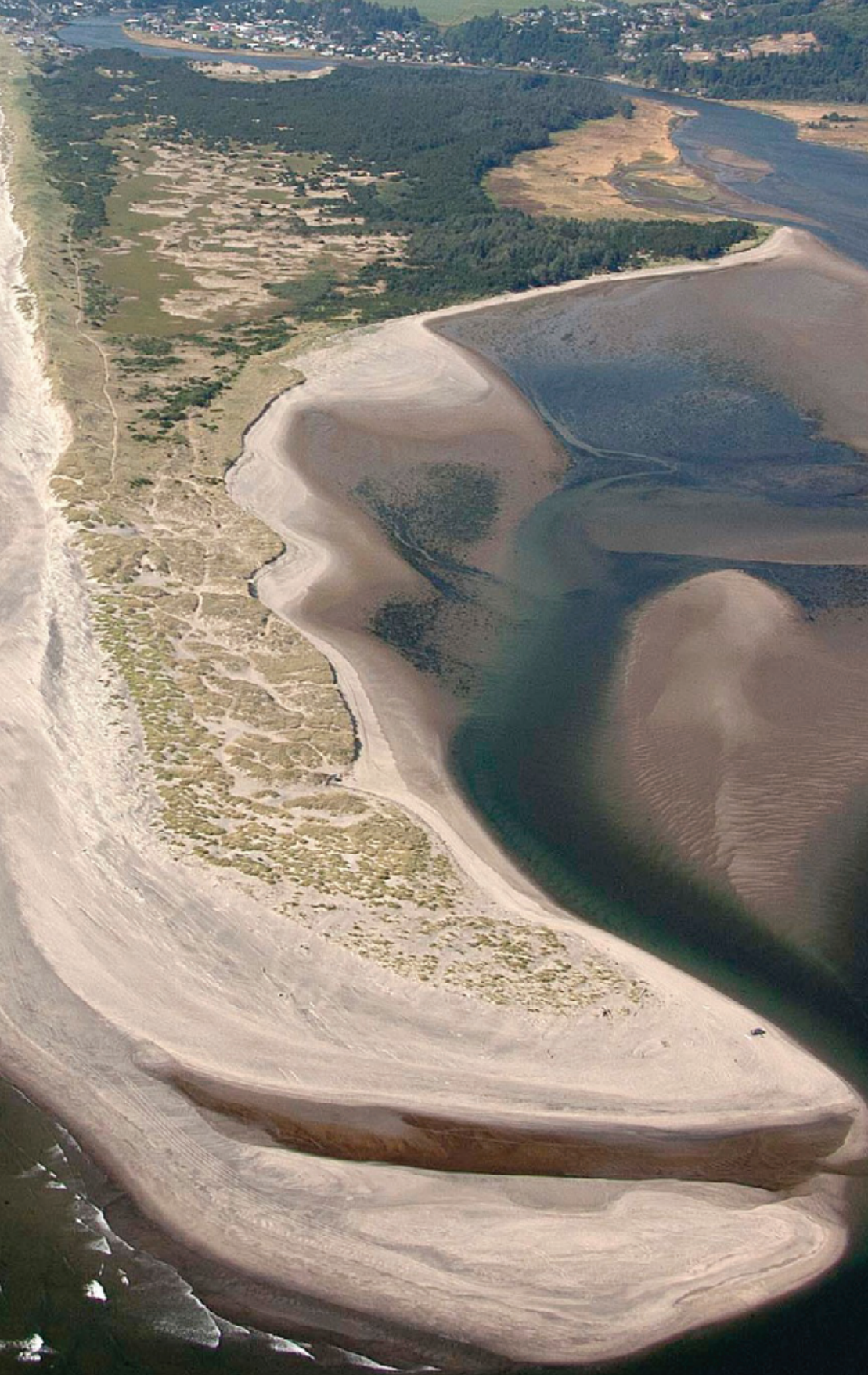


Cover. The cover is an oblique aerial photograph of Nestucca Spit, Oregon, looking north toward Pacific City, Cape Kiwanda, and Cape Lookout. Photograph by Erica Harris, Oregon Department of Geology and Mineral Industries. 


\section{National Assessment of Shoreline Change: Historical Shoreline Change Along the Pacific Northwest Coast}

By Peter Ruggiero, Meredith G. Kratzmann, Emily A. Himmelstoss, David Reid, Jonathan Allan, and George Kaminsky

Open-File Report 2012-1007 


\title{
U.S. Department of the Interior SALLY JEWELL, Secretary
}

\section{U.S. Geological Survey Suzette M. Kimball, Acting Director}

\author{
U.S. Geological Survey, Reston, Virginia: 2013
}

For more information on the USGS - the Federal source for science about the Earth, its natural and living resources, natural hazards, and the environment, visit http://www.usgs.gov or call 1-888-ASK-USGS.

For an overview of USGS information products, including maps, imagery, and publications, visit http://www.usgs.gov/pubprod

To order this and other USGS information products, visit http://store.usgs.gov

Any use of trade, firm, or product names is for descriptive purposes only and does not imply endorsement by the U.S. Government.

Although this information product, for the most part, is in the public domain, it also may contain copyrighted materials as noted in the text. Permission to reproduce copyrighted items must be secured from the copyright owner.

Suggested citation:

Ruggiero, Peter, Kratzmann, M.G., Himmelstoss, E.A., Reid, David, Allan, John, and Kaminsky, George, 2013, National assessment of shoreline change-Historical shoreline change along the Pacific Northwest coast: U.S. Geological Survey Open-File Report 2012-1007, 62 p., http://dx.doi.org/10.3133/ofr20121007. 


\section{Acknowledgements}

This report was made possible by the hard work and generous cooperation of many individuals. We thank the National Oceanic and Atmospheric Administration (NOAA) for providing digital historical shorelines, scans of selected NOAA topographic sheets (T-sheets), and datum corrections so that T-sheets could be rectified before they were digitized by the U.S. Geological Survey (USGS). We would like to acknowledge Paul D. Komar for his extensive research on Pacific Northwest coastal processes and shoreline changes. Much of this report is derivative of his pioneering efforts. Special thanks to the late Asbury H. Sallenger, Jr., whose vision and leadership resulted in the National Assessment of Shoreline Change Project; we will miss you Abby. Thanks to Kate Dallas, Michael Berry, Diana Di Leonardo, Nick Cohn, Katy Serafin, and Jeff Wood of Oregon State University and Guy Gelfenbaum and Cheryl Hapke of the USGS who provided reviews of an earlier version of this manuscript. 
This page has been left blank intentionally. 


\section{Contents}

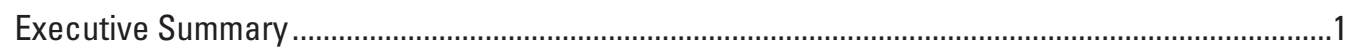

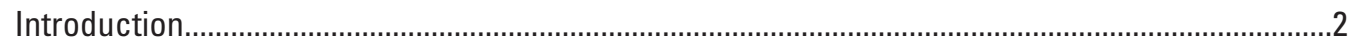

U.S. Geological Survey National Assessment of Shoreline Change Project.............................2

The Role of State and Federal Governments ......................................................................

Previous National and Pacific Northwest Shoreline Assessments ...............................................

Methods of Analyzing Shoreline Change ...............................................................................

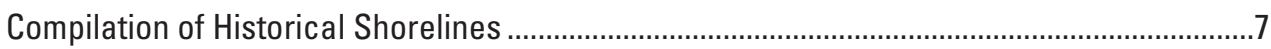

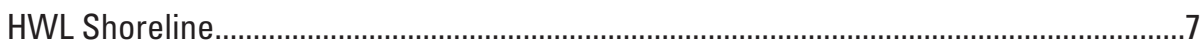

Lidar-Derived MHW Shoreline ..................................................................................10

The Proxy-Datum Bias Correction Between HWL and MHW Shorelines.................................11

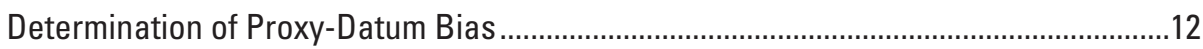

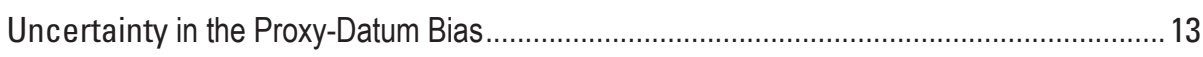

Use of the Proxy-Datum Bias and Bias Uncertainty in Shoreline Change Analysis ......13

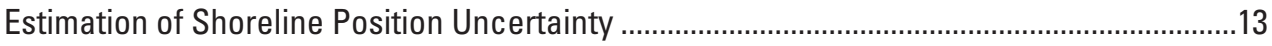

HWL Shoreline Position Uncertainty .......................................................................14

Lidar-Derived MHW Shoreline Position Uncertainty ......................................................14

Calculation and Interpretation of Shoreline Change Rates .................................................15

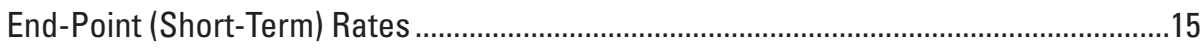

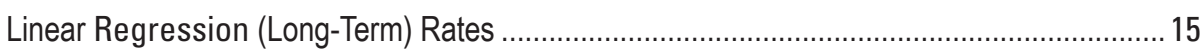

Estimation of Shoreline Change Rate Uncertainty ..............................................................16

Rate Uncertainty at Individual Transects .............................................................. 16

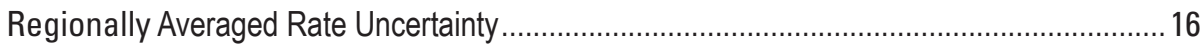

Human Beach Alterations That Influence Rates of Change ...................................................17

Geology and Geomorphology of the Pacific Northwest Coast .......................................................17

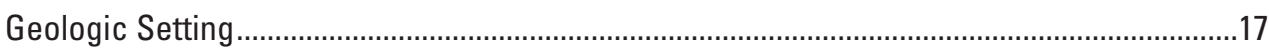

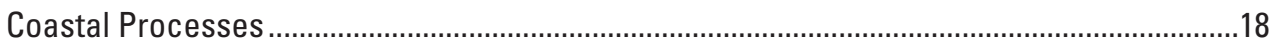

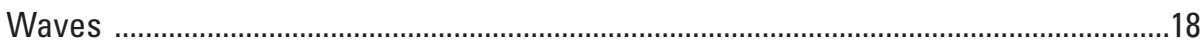

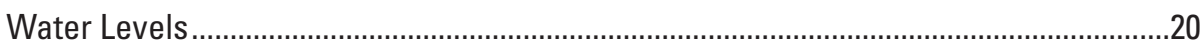

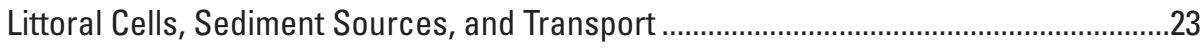

Coastal Landforms of the Pacific Northwest Coast..................................................................2

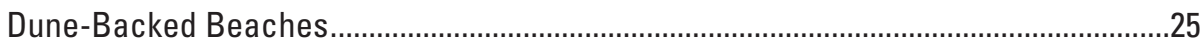

Cliff- and Bluff-Backed Beaches ......................................................................................27

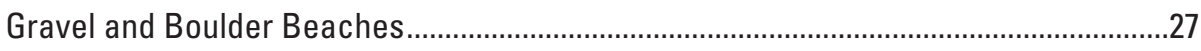

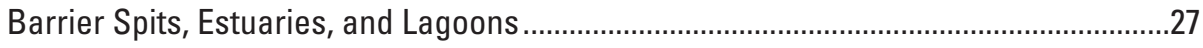

Rocky Shorelines and Shore Platforms ......................................................................28

Plunging Cliffs.........................................................................................................28

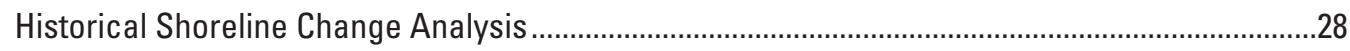

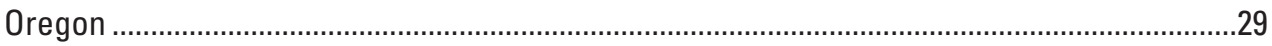

Southern Oregon —California Border to Cape Blanco ....................................................29

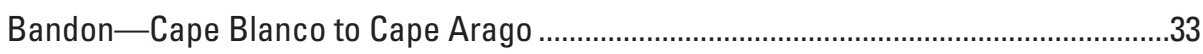

Coos Bay-Cape Arago to Cape Perpetua ………………...........................................35

Lincoln County-Cape Perpetua to Cascade Head ...........................................................37 
Tillamook County—Cascade Head to Cape Falcon .........................................................40

Cannon Beach—Cape Falcon to Tillamook Head ............................................................44

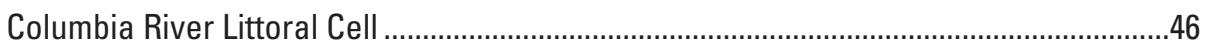

Columbia River Littoral Cell (Clatsop Plains Subcell)—Tillamook Head to the

Columbia River ........................................................................................... 48

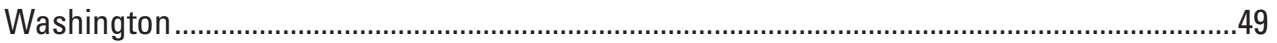

Columbia River Littoral Cell (Long Beach Subcell)—Columbia River to Willapa Bay....49

Columbia River Littoral Cell (Grayland Plains Subcell)—Willapa Bay to Grays Harbor

Columbia River Littoral Cell (North Beach Subcell)—Grays Harbor to Point

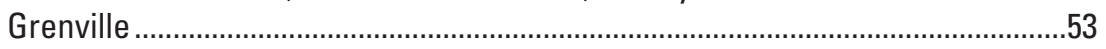

Olympic Peninsula—Point Grenville to La Push..............................................................53

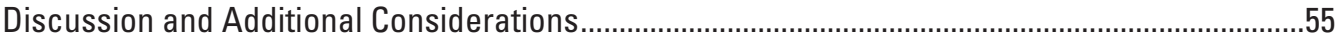

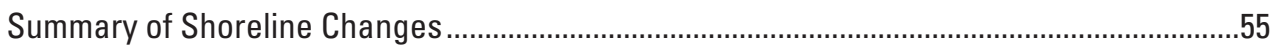

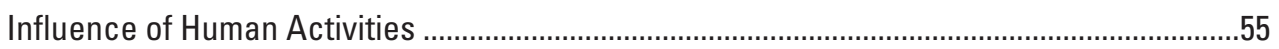

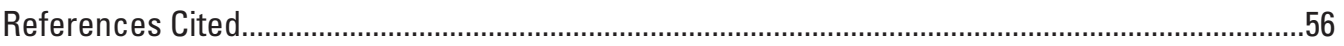

\section{Figures}

1. Index map of the Oregon and Washington coast showing the eight analysis regions used to present shoreline change results in this report.

2. Index map of $A$, Oregon and $B$, Washington showing geographic names discussed in this report

3. Map showing the Columbia River littoral cell, which spans 165 kilometers along the coast of northwestern Oregon and southwestern Washington

4. Graphs showing an example of a lidar profile of $A$, the entire cross-shore region and $B$, an expanded view of the foreshore region..

5. Shaded relief map showing the tectonic setting of the Pacific Northwest, with the collision and subduction of the oceanic plates beneath the continental North American plate

6. Photograph of Cascade Head, Oregon, an example of a major Pacific Northwest headland formed by Miocene era Columbia River basalts and the Salmon River Estuary......

7. Graphs showing monthly mean, $A$, significant wave height, B, period, and direction, C, from the University of California, San Diego Coastal Data Information Program buoy 036 at Grays Harbor, Washington

8. Graph showing seasonal variability in the monthly mean water levels derived from analyses of the Yaquina Bay, Oregon, tide-gage data, including the long-term averages and the ranges for the 1982-3 and 1997-8 El Niño years.

9. Graphs showing trends and variations in summer relative sea levels for the Pacific Northwest tide gage records. RMSE, root mean square error; RSLR, relative sea level rise

10. Graph showing alongshore varying rates of relative sea level rise (black line) as determined by three methods

11. Map showing the 18 littoral cells that make up the coast of Oregon, including the Clatsop Plains subcell of the Columbia River littoral cell, which extends into Washington. 
12. Sand movement along the beaches within Oregon's littoral cells between rocky headlands due to the seasonal changes in wave directions, comparing the equilibrium balance during $A$, typical years with $B$, major El Niño events when the waves transport greater volumes of sand (gray shading) to the north (blue shading), resulting in zones of hotspot erosion (red shading)

13. Photographs showing coastal landforms along the Pacific Northwest coast ...............26

14. Graphs showing long- (1800s through 2002) and short-term (1960s through 2002) shoreline change rates (black lines on plots) for the southern Oregon analysis region.

15. Photograph showing oblique aerial view of Hunter Creek, Oregon, in the Gold Beach littoral cell

16. Graphs showing long- (1800s through 2002) and short-term (1960s through 2002) shoreline change rates (black lines on plots) for the Bandon analysis region in Oregon

17. Photograph showing a bluff-backed beach of the type that characterize much of the shoreline near Bandon, Oregon

18. Graphs showing long- (1800s through 2002) and short-term (1960s through 2002) shoreline change rates (black lines on plots) for the Coos Bay analysis region in Oregon

19. Oblique aerial view of the Coos Bay dune sheet in Oregon .37

20. Graphs showing long- (1800s through 2002) and short-term (1960s through 2002) shoreline change rates (black lines on plots) for the Lincoln County analysis region in Oregon

21. Photographs of Alsea Spit, Oregon; taken by Paul Komar Oregon State University ......39

22. Graphs showing long- (1800s through 2002) and short-term (1960s through 2002) shoreline change rates (black lines on plots) for the Tillamook County analysis region in Oregon

23. Photograph showing a riprap structure near Rockaway Beach, Oregon

24. Graph showing alongshore variability in beach volume changes derived from an analysis of available lidar data for 1997 through 2002 for the Rockaway littoral cell in Oregon

25. Graphs showing long- (1800s through 2002) and short-term (1960s through 2002) shoreline change rates (black lines on plots) for the Cannon Beach analysis region in Oregon

26. Photograph looking north at Arch Cape, Oregon

27. Graphs showing long- (1800s through 2002) and short-term (1960s or 80s through 2002) shoreline change rates (black lines on plots) for the Columbia River littoral cell in Oregon and Washington.

28. Photograph of the Clatsop Plains subcell in Oregon looking south toward Tillamook Head, Oregon, in the distance

29. Oblique aerial photograph of the Long Beach subcell in Washington looking north .....49

30. Graphs showing an example profile along the prograding shoreline of the Long Beach Peninsula, Washington

31. Oblique aerial photograph of the Grayland Plains subcell in Washington looking northwest...

32. Graphs showing an example profile along a stretch of eroding shoreline in the Grayland Plains subcell near Westport, Washington; from Northwest Association of Networked Ocean Observing Systems

33. Oblique aerial photograph of the North Beach subcell in Washington looking north....53 
34. Graphs showing long- (1800s through 2002) and short-term (1920s-2002) shoreline change rates (black lines on plots) for the Olympic Peninsula analysis region in Washington

35. Survey line drawings prepared by the U.S. Army Corps of Engineers before and during construction of the Coquille River jetties adjacent to Bandon, Oregon 56

\section{Tables}

1. Providers and original sources of historical shorelines for Oregon and Washington......9

2. Shorelines used to calculate short- and long-term change rates for Oregon and Washington.

3. List of tide gage measurements used to calculate mean high water elevation

4. Absolute horizontal and vertical differences between high water and mean high water shorelines

5. Average uncertainties for the Pacific Northwest shorelines

6. Regional geomorphic coastal features of Oregon and Washington

7. Long-term shoreline change rate uncertainties, rates, and range of rates for the Pacific Northwest coast

8. Short-term shoreline change rate uncertainties, rates, and range of rates for the Pacific Northwest coast.

\section{Conversion Factors and Datum}

\begin{tabular}{lcl}
\hline \multicolumn{1}{c}{ Multiply } & By & \multicolumn{1}{c}{ To obtain } \\
\hline meter $(\mathrm{m})$ & Length & \\
kilometer $(\mathrm{km})$ & 3.281 & foot $(\mathrm{ft})$ \\
\hline & 0.6214 & mile $(\mathrm{mi})$ \\
\hline square meter $\left(\mathrm{m}^{2}\right)$ & Area & \\
square kilometer $\left(\mathrm{km}^{2}\right)$ & 10.76 & square foot $\left(\mathrm{ft}^{2}\right)$ \\
\hline & 0.3861 & square mile $\left(\mathrm{mi}^{2}\right)$ \\
\hline cubic meter $\left(\mathrm{m}^{3}\right)$ & Volume & \\
\hline & 35.31 & cubic foot $\left(\mathrm{ft}^{3}\right)$ \\
\hline cubic meter per year $\left(\mathrm{m}^{3} / \mathrm{yr}\right)$ & Flow rate & \\
meter per year $(\mathrm{m} / \mathrm{yr})$ & 0.000811 & acre-foot per year $(\mathrm{acre}-\mathrm{ft} / \mathrm{yr})$ \\
cubic meter per second $\left(\mathrm{m}^{3} / \mathrm{s}\right)$ & 3.281 & foot per year $\mathrm{ft} / \mathrm{yr})$ \\
millimeter per year $(\mathrm{mm} / \mathrm{yr})$ & 35.31 & cubic foot per second $\left(\mathrm{ft}^{3} / \mathrm{s}\right)$ \\
\hline
\end{tabular}

Vertical coordinate information is referenced to the North American Vertical Datum of 1988 (NAVD 88).

Horizontal coordinate information is referenced to the North American Datum of 1983 (NAD 83).

Elevation, as used in this report, refers to distance above the vertical datum. 


\section{Abbreviations}

$\begin{array}{ll}\text { DOGAMI } & \text { Oregon Department of Geology and Mineral Industries } \\ \text { FEMA } & \text { Federal Emergency Management Agency } \\ \text { HWL } & \text { high water line } \\ \text { MHW } & \text { mean high water } \\ \text { NOAA } & \text { National Oceanic and Atmospheric Administration } \\ \text { PNW } & \text { Pacific Northwest } \\ \text { USACE } & \text { U.S. Army Corps of Engineers } \\ \text { USGS } & \text { U.S. Geological Survey }\end{array}$


This page has been left blank intentionally. 


\title{
National Assessment of Shoreline Change: Historical Shoreline Change Along the Pacific Northwest Coast
}

\author{
By Peter Ruggiero, ${ }^{1}$ Meredith G. Kratzmann, ${ }^{2}$ Emily A. Himmelstoss, ${ }^{2}$ David Reid, ${ }^{2}$ Jonathan Allan, ${ }^{3}$ \\ and George Kaminsky ${ }^{4}$
}

\section{Executive Summary}

Beach erosion is a chronic problem along most open ocean shores of the United States. As coastal populations continue to increase and infrastructure is threatened by erosion, there is increased demand for accurate information regarding past and present trends and rates of shoreline movement. There is also a need for a comprehensive analysis of shoreline movement that is consistent from one coastal region to another. To meet these national needs, the U.S. Geological Survey (USGS) is conducting an analysis of historical shoreline changes along the open-ocean sandy shores of the conterminous United States and parts of Hawaii, Alaska, and the Great Lakes. One purpose of this work is to develop standard, repeatable methods for mapping and analyzing shoreline movement so that periodic, systematic, and internally consistent updates regarding coastal erosion and land loss can be made nationally. In the case of the analysis of shoreline change in the Pacific Northwest (PNW), the shoreline is the interpreted boundary between the ocean water surface and the sandy beach.

This report on the PNW coasts of Oregon and Washington is the seventh in a series of regionally focused reports on historical shoreline change. Previous investigations include analyses and descriptive reports of the U.S. Gulf of Mexico (Morton and others, 2004), the southeastern Atlantic (Morton and Miller, 2005), the sandy shorelines (Hapke and others, 2006) and coastal cliffs (Hapke and Reid, 2007) of California, the New England and mid-Atlantic coasts (Hapke and others, 2011), and parts of the Hawaii coast (Fletcher and others, 2012). Like the earlier reports in this series, this report summarizes the methods of analysis, interprets the results of the analysis, provides explanations regarding long- and short-term trends and rates of shoreline change, and describes how different coastal communities are responding to coastal erosion. This report differs from the early USGS reports in the series in that those shoreline change analyses incorporated only four total shorelines to represent specific time

\footnotetext{
${ }^{1}$ Oregon State University.

${ }^{2}$ U.S. Geological Survey.

${ }^{3}$ Oregon Department of Geology and Mineral Industries.

${ }^{4}$ Washington Department of Ecology.
}

periods. This assessment of the PNW incorporates all available shorelines that meet minimum quality standards for resolution and positional accuracy. Shoreline change evaluations are based on a comparison of historical shoreline positions digitized from maps or aerial photographic data sources with recent shorelines, at least one of which is derived from lidar surveys. The historical shorelines cover a variety of time periods ranging from the $1800 \mathrm{~s}$ through the 1980s, whereas the lidar shoreline is from 2002. Long-term rates of change are calculated using all available shoreline data and short-term rates of change are calculated using the lidar shoreline and the historical shoreline that will produce an assessment for a 15- to 35-year period. The rates of change presented in this report represent conditions up to the date of only the most recent shoreline data and therefore are not intended for predicting future shoreline positions or rates of change.

The PNW coast was subdivided into eight analysis regions for the purpose of graphically reporting regional trends in shoreline change rates. The average rate of long-term shoreline change for the entire PNW coast was 0.9 meter per year $(\mathrm{m} / \mathrm{yr})$ of progradation with an uncertainty of $0.07 \mathrm{~m} / \mathrm{yr}$. This rate is based on 8,823 individual transects, of which 36 percent was determined to be eroding. Long-term shoreline change was generally more progradational in Washington than in Oregon. This is primarily due to the influence of the Columbia River and human perturbations to the natural system, particularly the construction of jetties at both the mouth of the Columbia River and at Grays Harbor, Washington. The majority of the beaches in southwestern Washington have responded to these largescale engineered structures by experiencing dramatic beach progradation during the past century. Although these beaches are still responding to the human effects, in several locations beaches that had been rapidly prograding are now either prograding at a slower rate or eroding.

The average rate of short-term shoreline change in the PNW was also progradational at a rate of $0.9 \mathrm{~m} / \mathrm{yr}$ with an uncertainty of $0.03 \mathrm{~m} / \mathrm{yr}$. This rate is based on 9,087 individual transects, of which 44 percent was determined to be eroding. Similar to the results of the long-term shoreline change analysis, the shorelines in Washington were typically more progradational than those in Oregon in the short term. However, many stretches of coast in Oregon are either less accretional, changed from accretional to erosional, or more erosional when comparing the long- and short-term rate calculations. In the long and short term, there 
are significantly different historical shoreline change trends for beaches deriving their modern sediments from the Columbia River in southwestern Washington and northwestern Oregon, and beaches elsewhere in the PNW. The majority of shorelines in Oregon and in Washington's Olympic Peninsula are not influenced by the human effects to the Columbia River littoral cell and typically have not experienced the human-induced century-scale trends apparent in southwestern Washington and northwestern Oregon.

An increase in erosion hazards in much of Oregon may be related to the effects of sea-level rise and increasing storm wave heights. Of importance, particularly in the short term, is the alongshore variability in land uplift rates due to tectonics, which results in an alongshore varying rate of relative sea level rise that appears to at least partially control the regional variability in short-term shoreline change rates. Other climate related processes, such as the occurrence of major El Niño events, also significantly affect the shoreline changes in the region. Major El Niño events elevate monthly mean sea levels by tens of centimeters throughout the winter and produce a shift in the storm tracks, resulting in alongshore redistributions in sand volumes on the beaches, leading to hotspot beach erosion and property losses north of headlands and tidal inlets to bays and estuaries. There are limited modern-day sources of sand to Oregon's beaches, with much of the sand being relict in having arrived thousands of years ago at a time of lowered sea levels when headlands did not prevent the alongshore movement of the beach sediments, the result being that many beaches today are deficient in sand volumes and therefore do not provide sufficient buffer protection to backshore properties during winter storms.

\section{Introduction}

\section{U.S. Geological Survey National Assessment of Shoreline Change Project}

Sandy ocean beaches represent some of the most popular tourist and recreational destinations in the United States and constitute some of the most valuable real estate in the country. These changing and ephemeral interfaces between water and land are often the sites of concentrated residential and commercial development. However, because sandy beaches are frequently subjected to a range of natural hazards that can include flooding, storm effects, coastal erosion, and tsunami inundation, the U.S. Geological Survey (USGS) is conducting a national assessment of coastal change hazards. One component of this effort, the National Assessment of Shoreline Change Project, documents changes in shoreline position as a proxy for coastal change. Shoreline position is one of the most commonly monitored indicators of environmental change (Morton, 1996), and it is an easily understood feature representing the historical movement of beaches.

A principal component of the USGS national assessment is to develop a consistent methodology that allows for periodic updates that incorporate improved methods and data accuracy yet still results in a dataset that is internally consistent at a national scale. In particular, recent methods for developing datum-based shorelines using lidar data and assessing coastal change will provide the opportunity to achieve and incorporate more comprehensive error assessments in the future. The primary objectives of the assessment are to investigate improved methods of assessing and monitoring shoreline movement and develop a better understanding of the processes controlling shoreline change. Achieving these objectives requires research that (1) examines the original sources of shoreline data (maps, aerial photographs, lidar), (2) evaluates the errors associated with each data source, (3) investigates new methods for developing datum-based shorelines and quantifying potential bias and errors associated with integrating shoreline proxies from different sources, (4) develops standard, uniform methods of shoreline change analysis, (5) assesses the effects of human activities on shoreline movement and rates of change, and (6) integrates shoreline change observations with other information, such as geologic framework and sediment transport data.

Results of the National Assessment of Shoreline Change Project are organized by coastal regions. Previous investigations include analyses and descriptive reports of the U.S. Gulf of Mexico (Morton and others, 2004), the southeastern Atlantic (Morton and Miller, 2005), the sandy shorelines (Hapke and others, 2006) and coastal cliffs (Hapke and Reid, 2007) of California, the New England and mid-Atlantic coasts (Hapke and others, 2011), and parts of the Hawaii coast (Fletcher and others, 2012). In this report, historical changes along the outer coasts of Oregon and Washington in the Pacific Northwest (PNW) are summarized. The PNW study area was subdivided into eight analysis regions for the purpose of presenting regional trends for the shoreline change rate data (fig. 1).

This report is part of a series of reports summarizing methods, results, and implications of the results in addition to maps illustrating rates of shoreline change. The format, style, and methods used in this report closely follow that developed by Hapke and others $(2006,2011)$. The geographic information system (GIS) data are published in Kratzmann and others (2013). Rates of shoreline change are published in this report for the purpose of regional characterization. The shoreline change results and products prepared by the USGS are not intended for detailed site-specific analysis of shoreline movement, nor are they intended to replace any official sources of shoreline change information identified by local or State government agencies or other Federal entities as used for regulatory purposes. Rates of shoreline change presented in this report may differ from other published rates, and differences do not necessarily indicate that the other rates are inaccurate. Some discrepancies are expected, considering the many possible ways of determining shoreline positions and rates of change and the inherent uncertainty in calculating these rates. Rates of shoreline change presented in this report represent shoreline movement under past conditions. The results are not intended for predicting future shoreline positions or future rates of shoreline change. 


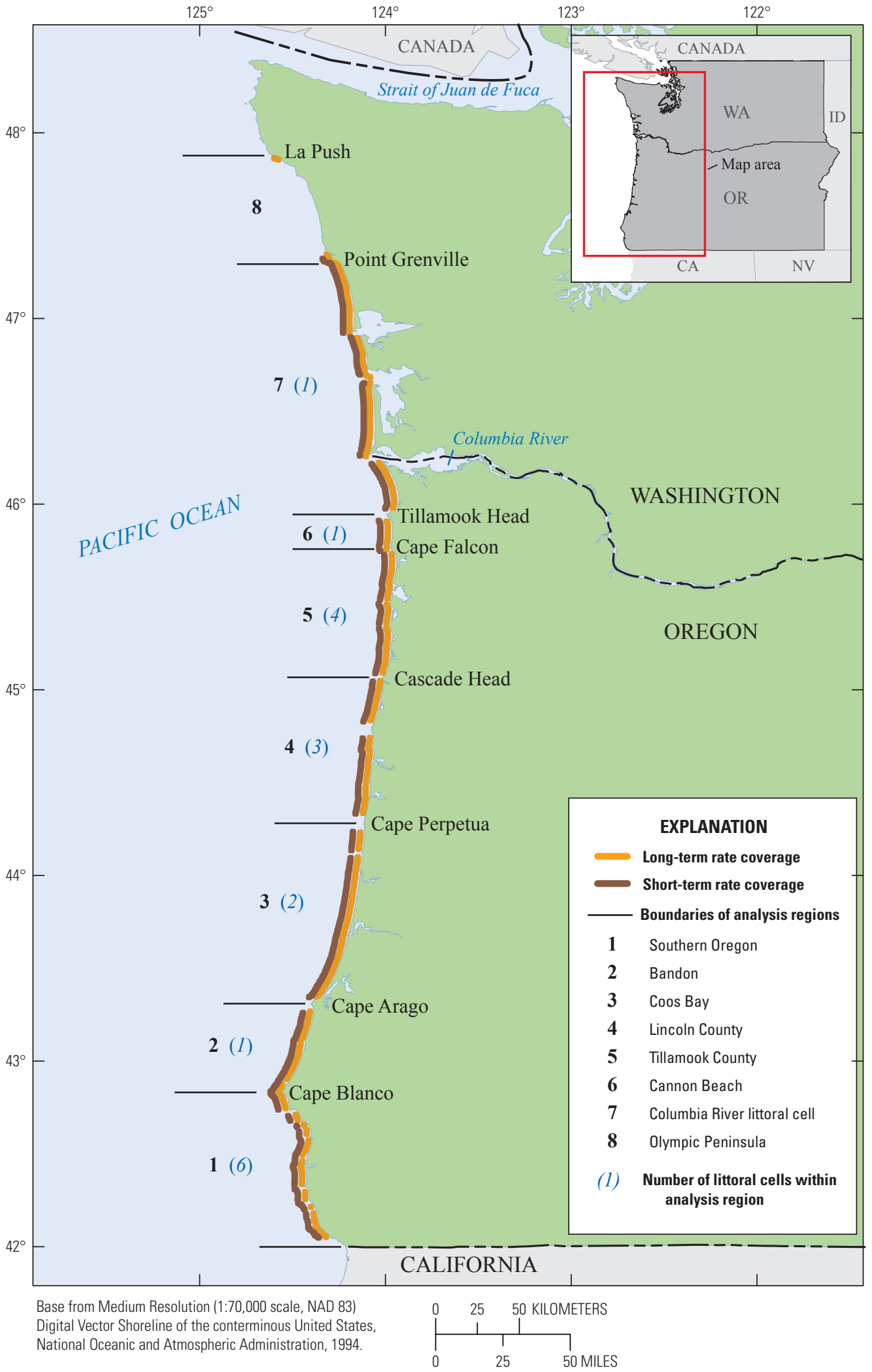

Figure 1. Index map of the Oregon and Washington coast showing the eight analysis regions used to present shoreline change results in this report. The number of littoral cells within each region is noted in parentheses. 


\section{The Role of State and Federal Governments}

One reason for conducting this national assessment of shoreline change is that there is no widely accepted standardized method for analyzing shoreline changes. Each State or region has its own data needs and coastal zone management responsibilities (for example, construction of setback lines), and therefore different techniques and standards are used to compile shorelines and to calculate rates of shoreline movement. Consequently, existing calculated rates of shoreline change and projected shoreline positions are inconsistent from State to State and even within States and cannot be compared directly. These inconsistencies were clearly demonstrated by the Federal Emergency Management Agency (FEMA)-sponsored erosion studies (Crowell and Leatherman, 1999) that were used as the basis for evaluating erosion hazards (The H. John Heinz III Center for Science, Economics, and the Environment, 2000). The USGS national assessment of shoreline change represents the first time that shorelines from original data sources have been compiled and rates of shoreline change have been calculated across the Nation using internally consistent methods. The results of this analysis allow direct comparison of rates of change from one coastal segment to another and form the basis for future comparison of shoreline position.

Several Federal agencies (for example, FEMA, the National Oceanic and Atmospheric Administration (NOAA), and the U.S. Army Corps of Engineers (USACE)) have regulatory or administrative responsibilities pertaining to shorelines. Yet these responsibilities are quite different, requiring varied approaches and offering substantial opportunities for cooperation. For example, the USACE is authorized and funded by Congress to report on the economic and environmental implications of shoreline change and the costs of erosion mitigation. Their national shoreline management study (Stauble and Brumbaugh, 2003) is being conducted using existing shoreline data. The USGS shares data and information, such as the lidar-derived shoreline and rates of change, in support of the USACE assessment. NOAA is mandated to establish the official shoreline boundary for the Nation using tidal data. The emphasis of NOAA's mandate is on safe navigation and using the shoreline to generate nautical charts. NOAA also has a program (Vdatum) that allows users to convert data from different vertical references into a common system, which greatly assists other agencies in establishing alternative shorelines for a variety of purposes. Congress authorized and funded FEMA to report on the economic effect of erosion hazards on coastal communities and on claims to the National Flood Insurance Fund. To accomplish this, FEMA contracted State agencies and academic researchers to conduct a pilot study of erosion hazards that included shoreline-change data for limited geographic areas (including segments of the PNW). The USGS is responsible for conducting research pertaining to coastal-change hazards, including shoreline change, understanding the processes that cause coastal change, and developing models to predict future change. The USGS is the only government agency that has a dedicated program to monitor coastal change into the future using consistent methods nationwide. Such a program is critically important to assess national issues, such as identifying regions of chronic erosion due to storms or the coastal effects of sea-level rise.

\section{Previous National and Pacific Northwest Shoreline Assessments}

The USACE conducted the first national assessment of coastal erosion (U.S. Army Corps of Engineers, 1971). That study identified areas of critical and noncritical erosion with an emphasis on economic development and potential for property loss, but rates of shoreline movement were not evaluated. Dolan and others (1985) conducted a comprehensive analysis of shoreline change nationwide. Their analysis was based on a compilation of shoreline change rates provided by other contributors and derived from their own studies of the MidAtlantic region. Rates of change were presented on maps, and the long-term trends of erosion and accretion were summarized in an accompanying text.

Unlike much of the U.S. coast, population pressure on the PNW coast has historically been relatively low. Possibly as a result of this, early shoreline change studies in Oregon and Washington focused mainly on changes associated with the construction of jetties (for example, Komar and others, 1976), case studies of site-specific coastal erosion problems (for example, Terich and Komar, 1974; Komar and Rea, 1976; Terich and Levenseller, 1986), and responses to interannual climatic variations associated with variability in the El Niño southern oscillation (ENSO; for example, Peterson and others, 1990). Subsequent shoreline change analyses in Oregon have primarily been performed at the littoral-cell scale (for example, Priest and others, 1994; Priest, 1999; Allan and Priest, 2001; Allan and others, 2003; see the Coastal Processes section for more information about littoral cells). A comprehensive and consistent statewide coastal change assessment for Oregon has never been completed.

Historically (since the 1880s), much of the shoreline in southwestern Washington prograded rapidly, and coastal management issues dealt with accreting and drifting dunes that interrupted views and restricted public access. Coastal erosion hazards were treated as localized problems with minimal regional implications. Therefore, few early studies exist that investigate shoreline change patterns along the outer Washington coast (as opposed to the inland shorelines of the Puget Sound). However, the studies of Phipps and Smith (1978) and Phipps (1990) did qualitatively demonstrate the long-term trend of progradation on Long Beach (map accuracies were about \pm 30.5 meters $(\mathrm{m})$ ) and a subsequent deceleration of this trend, particularly toward the southern end of the peninsula near the mouth of the Columbia River. See figure 2 for an index map of the geographic names within Oregon (fig. 2A) and Washington (fig. 2B) discussed in this report. 


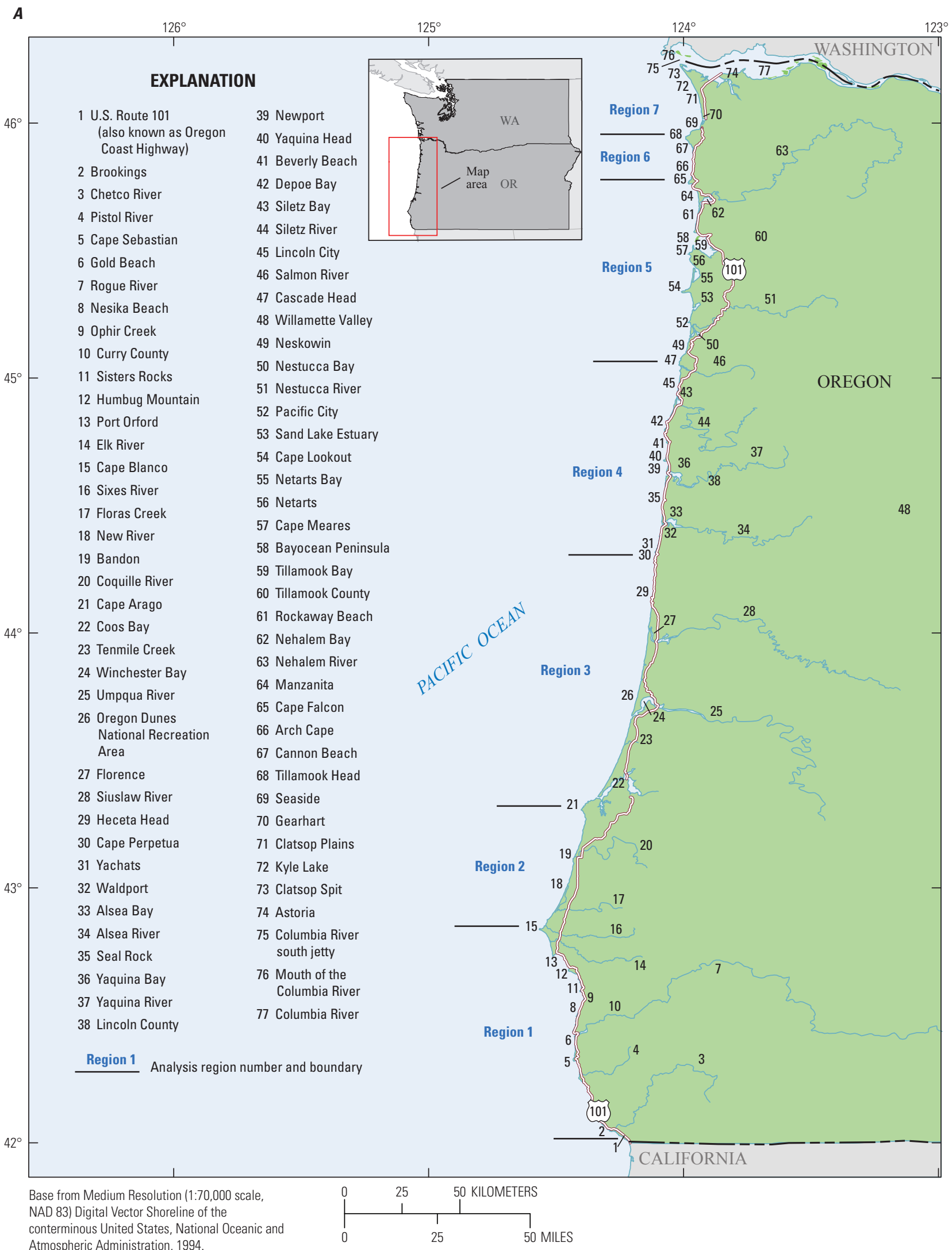

Figure 2. Index map of $A$, Oregon and $B$, Washington showing geographic names discussed in this report. 


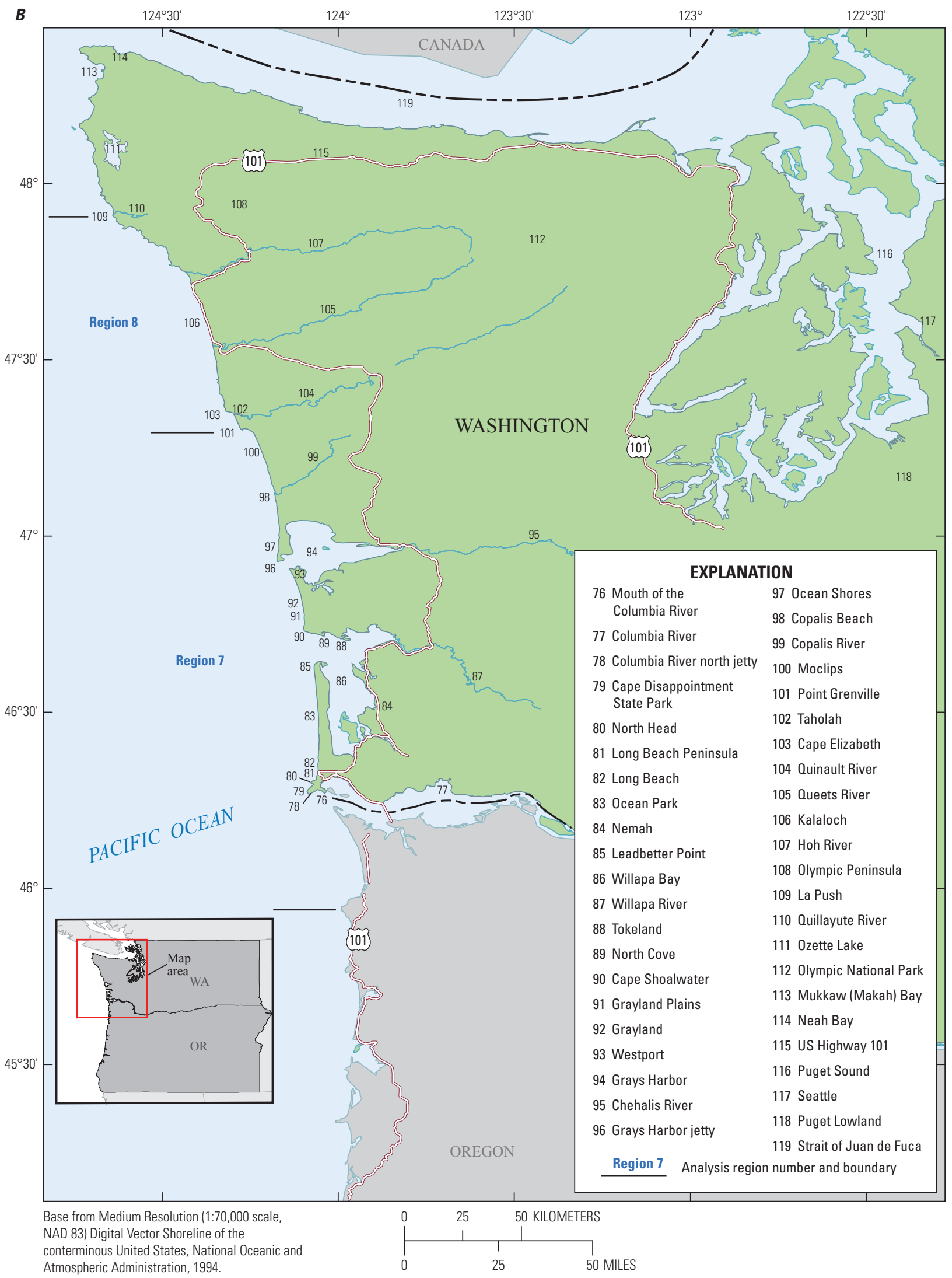

Figure 2. Index map of $A$, Oregon and $B$, Washington showing geographic names discussed in this report.-Continued 
In the 1990s, it became clear that the rates of progradation in parts of southwestern Washington had indeed slowed, and for the first time, the State was faced with a suite of outer coast erosion issues. A storm in December 1993 breached a narrow neck of land at the Grays Harbor, Washington South Jetty, threatening the Westport, Wash., wastewater treatment plant (fig. 2A). Within just a few years of the jetty breach, Federal, State, and local governments invested more than $\$ 70$ million in coastal stabilization projects within the region, much of it in emergency response to threatened infrastructure. By the mid-1990s, scientists and engineers working with coastal communities identified a number of erosion hotspots in places that had previously been accreting. For example, coastal erosion in Washington at Ocean Shores, Westport, Cape Shoalwater, and Cape Disappointment State Park (formerly Fort Canby) and in Oregon at Clatsop Spit (fig. 2) was so severe that the concerns of citizens and coastal communities led elected officials and Federal and State resource agencies to initiate research.

To obtain a broad understanding of the coastal erosion problems and enable Federal, State, and local agencies to anticipate and avoid emergencies, the Southwest Washington Coastal Erosion Study was initiated (Gelfenbaum and Kaminsky, 2010). The study was initially conceived in 1994 based on the recognition of a lack of basic understanding of coastal processes and shoreline changes along the highly dynamic southwestern Washington and northwestern Oregon coasts. The multidisciplinary investigation of the Columbia River littoral cell (CRLC; fig. 3) was jointly sponsored by the USGS and the Washington Department of Ecology, with active participation from local communities and academics. The overall goal of the study was to understand the coastal system dynamics of the CRLC and to develop the knowledge foundation to inform Federal, State, and local decisionmaking, management strategies, land-use planning, resource allocations, and hazard reduction solutions. Three primary objectives were to (1) understand regional sediment system dynamics, (2) determine natural and anthropogenic influences on the littoral system, and (3) predict coastal behavior at management scales (in other words, over decades and tens of kilometers). These objectives were pursued through a wide range of investigations, including a comprehensive coastal change analysis. The Southwest Washington Coastal Erosion Study performed the first systematic processing and analysis of all regional historical shoreline and bathymetric survey data within the CRLC. Initial results are reported in Gelfenbaum and others (1999, 2001), Gibbs and Gelfenbaum (1999), Kaminsky and others (1999a,b, 2001), and Buijsman and others (2003a,b). The study of Kaminsky and others (2010) documents the complete analysis in which all reliable surveys, charts, and aerial photographs were used to quantify decadalscale changes at the three estuary entrances and four subcells of the CRLC (fig. 3).

Since the national shoreline change work of Dolan and others (1985), methods of obtaining, analyzing, displaying, and storing shoreline data have improved substantially.
Nevertheless, coastal scientists have not yet agreed on standard methods for analyzing and reporting shoreline changes, nor have they identified rigorous mathematical tests that are widely accepted for quantifying the change and associated errors. Consequently, there are critical needs for (1) a nationwide compilation of reliable shoreline data that include the most recent shoreline positions and (2) a standardization of methods for obtaining and comparing shoreline positions and mathematically analyzing the trends.

\section{Methods of Analyzing Shoreline Change}

\section{Compilation of Historical Shorelines}

Coastal researchers at universities and government agencies in the United States have been quantifying rates of shoreline movement and studying coastal change for decades. Before global positioning system (GPS) and lidar technologies were developed, the most commonly used sources of historical shoreline position were NOAA topographic sheets (T-sheets; Shalowitz, 1964) and aerial photographs. Extraction of shoreline position from these data sources involves georeferencing maps or aerial photographs and subsequently interpreting and digitizing a shoreline position. Depending on topography of the study area, the sources of the data, and scientific preference, different proxies for shoreline position are used to document coastal change, including the high water line (HWL), wet-dry line, vegetation line, dune toe or crest, toe or berm of the beach, cliff base or top, and the line of mean high water (MHW).

\section{HWL Shoreline}

The USGS national assessment of shoreline change analysis for the PNW coast incorporates shoreline positions from a variety of dates and data sources. The earliest shoreline data are derived from T-sheets dating back to the mid-1800s. Several organizations have provided the USGS with digital maps and (or) shoreline data (table 1). In addition, shorelines were digitized from many historical T-sheets that were georeferenced by the USGS. NOAA T-sheet indexes were used to determine T-sheet availability for shorelines that were not already available for download as Esri geographic information system (GIS) shapefiles. T-sheets were then requested from NOAA and received as scanned tagged image file format (TIFF) images. Existing digital shorelines from other data sources were compiled, and a quality assessment was performed.

T-sheets were rectified using ERDAS IMAGINE geographic imaging software by placing at least six wellspaced ground control points (GCPs) on selected T-sheet 


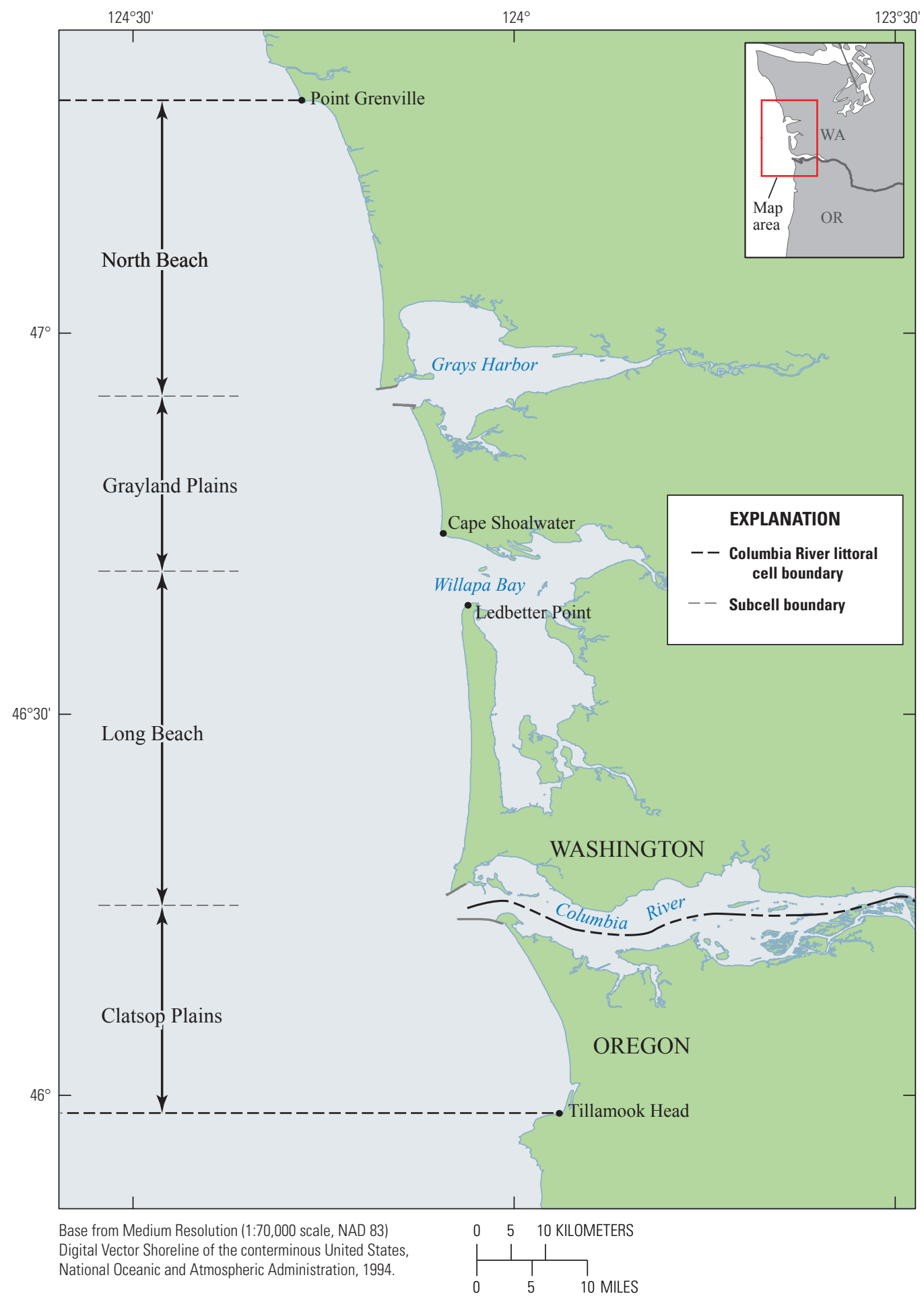

Figure 3. The Columbia River littoral cell, which spans 165 kilometers along the coast of northwestern Oregon and southwestern Washington. The CRLC consists of four subcells separated by the estuaries of the Columbia River, Willapa Bay, and Grays Harbor, Wash. 
Table 1. Providers and original sources of historical shorelines for Oregon and Washington.

\begin{tabular}{lll}
\hline \multicolumn{1}{c}{ Organization } & \multicolumn{1}{c}{ Original data source } & State \\
\hline National Oceanic and Atmospheric Administration & Scanned topographic sheets (T-sheets) & Oregon, Washington \\
$\begin{array}{l}\text { U.S. Geological Survey and National Aeronautics } \\
\text { and Space Administration }\end{array}$ & Airborne lidar from 2002 & Oregon, Washington \\
U.S. Geological Survey & Digital raster graphic (DRG) (based on aerial photography) & Oregon \\
Washington State Department of Ecology & Aerial photography taken for the Oregon Department of & Oregon \\
& Transportation in 1967 & Washington \\
Washington State Department of Ecology & Columbia River littoral cell (CRLC) aerial photography in the & \\
& 1960 s through 1990s & \\
\hline
\end{tabular}

graticules in geographic coordinates. Some T-sheets produced before 1930 required additional coordinate transformation information from NOAA to convert from the United States Standard Datum (USSD) to the North American Datum of 1927 (NAD 27). The datum transformation was applied to T-sheet graticule coordinates before rectification. The total root mean square error (RMSE) for the rectification process was maintained at less than 1 pixel, which is about $4 \mathrm{~m}$ at a scale of $1: 20,000$ and about $1.5 \mathrm{~m}$ at a scale of $1: 10,000$. Typically, the resulting RMSE was much less than 1 pixel. Newly georeferenced T-sheets were loaded into Esri ArcGIS, and shorelines were digitized. All shoreline vectors were converted to Universal Transverse Mercator (UTM) projection on the North American Datum of 1983 (NAD 83).

A key component of the national assessment of shoreline change hazards consists of a standardization of methods for determining shoreline positions and mathematically analyzing the trends. Previously released shoreline change reports contain shoreline positions and rates of change based on data from at least four shorelines from four distinct eras - $1800 \mathrm{~s}$, 1920s through 1930s, 1950s through 1970s, and 1998 through 2002. Unfortunately, in Oregon, T-sheet coverage from the 1950 s through the 1970s is sparse. To fill gaps in data, one option was to derive a shoreline from USGS digital raster graphics (DRGs); however, the uncertainty associated with this method warranted exploration of other potential data sources. Therefore, a shoreline was digitized from a set of continuous aerial photographs collected in 1967 under project OC-3 for the determination of the State's statutory vegetation line. The aerial photography that was acquired from the Oregon Department of Transportation (ODOT) extends along the entire coast of Oregon and is a collection of 1,611 photographs along roughly 50 to 60 flight paths for the open ocean beaches (no bays). The photographs were taken at 1:6,000 scale, such that 1 inch on the photograph is $152 \mathrm{~m}$ on the ground. The digital elevation model (DEM) used in the orthorectification process, which used Leica Photogrammetry Suite, was developed from 2002 lidar data.

Table 2 lists the range of years for shorelines compiled for each period by State. Details regarding shoreline dates for specific locations within each State are included in shoreline data files in Kratzmann and others (2013).
Table 2. Shorelines used to calculate short- and longterm change rates for Oregon and Washington.

[HWL, high water line; MHW, mean high water; DRG, digital raster graphics]

\begin{tabular}{|c|c|c|}
\hline Date $^{1}$ & Source & Type \\
\hline \multicolumn{3}{|c|}{ Short-term (end point) rate } \\
\hline \multicolumn{3}{|l|}{ Oregon: } \\
\hline 1967 & Aerial photography & HWL \\
\hline 2002 & Lidar & MHW \\
\hline \multicolumn{3}{|l|}{ Washington: } \\
\hline $1986-8$ & Aerial photography & HWL \\
\hline 2002 & Lidar & MHW \\
\hline \multicolumn{3}{|c|}{ Long-term (linear regression) rate } \\
\hline \multicolumn{3}{|l|}{ Oregon: } \\
\hline $1868-1955$ & T-sheet & HWL \\
\hline 1971-1974 & T-sheet & HWL \\
\hline 1967 & Aerial photography & HWL \\
\hline 1943-1999 & DRG & HWL \\
\hline 2002 & Lidar & MHW \\
\hline \multicolumn{3}{|l|}{ Washington: } \\
\hline $1869-1955$ & T-sheet & HWL \\
\hline 1963-1999 & Aerial photography & HWL \\
\hline 2002 & Lidar & MHW \\
\hline
\end{tabular}

${ }^{1}$ Dates listed are dates for which data are available for the Pacific Northwest (Oregon and Washington). Details regarding shoreline dates for specific locations within each State are included in the shoreline data files in Kratzmann and others (2013). 


\section{Lidar-Derived MHW Shoreline}

The most recent shoreline used in this report was derived from lidar data. The USGS, in collaboration with the National Aeronautics and Space Administration (NASA), has been using the NASA Airborne Topographic Mapper (ATM), an aircraft-mounted lidar system, to map coastal areas since 1997 (Krabill and others, 2000; Sallenger and others, 2003). The ATM surveys ground elevation using an elliptically rotating blue-green laser. Global Positioning System (GPS) positions and inertial navigation systems are used to correct for aircraft pitch, roll, and heading (Sallenger and others, 2003), providing ground elevations with accuracies of about \pm 15 centimeters (cm). The lidar surveys used to extract shorelines for this report were conducted in late summer 2002.

To compare the lidar data with historical shorelines, an operational MHW shoreline (fig. 4) was extracted from the lidar surveys using a method similar to that developed by Stockdon and others (2002). The operational MHW elevation in the PNW is $2.1 \mathrm{~m}$ above the North American Vertical Datum of 1988 (NAVD 88) and was determined by Weber and others (2005). The operational MHW elevation represents an average of MHW elevations from individual open-ocean or near-open-ocean tide gages. Tide gages and MHW elevations used in each region are listed in table 3 . The lidar-extracted MHW shoreline is not the same as a MHW shoreline surveyed by a licensed land surveyor. This is because the operational MHW elevation used for the lidar shoreline is an average of the MHW elevations at several tide gages. Furthermore, the lidar-extracted shoreline is intended only as a reference feature for measuring shoreline change. It is not intended to establish legal boundaries.

Shorelines were extracted from cross-shore profiles, which consist of bands of lidar data 2- to 4-m wide in the alongshore direction and spaced every $20 \mathrm{~m}$ along the coast. A least squares linear regression line is passed through the cluster of data that encompasses the operational MHW datum and is limited to the seaward-sloping beach foreshore (fig. 4B). The regression equation is then used to derive the horizontal intersection of the operational MHW datum with the profile, giving the shoreline position for that profile. Repeating this

$\boldsymbol{A}$

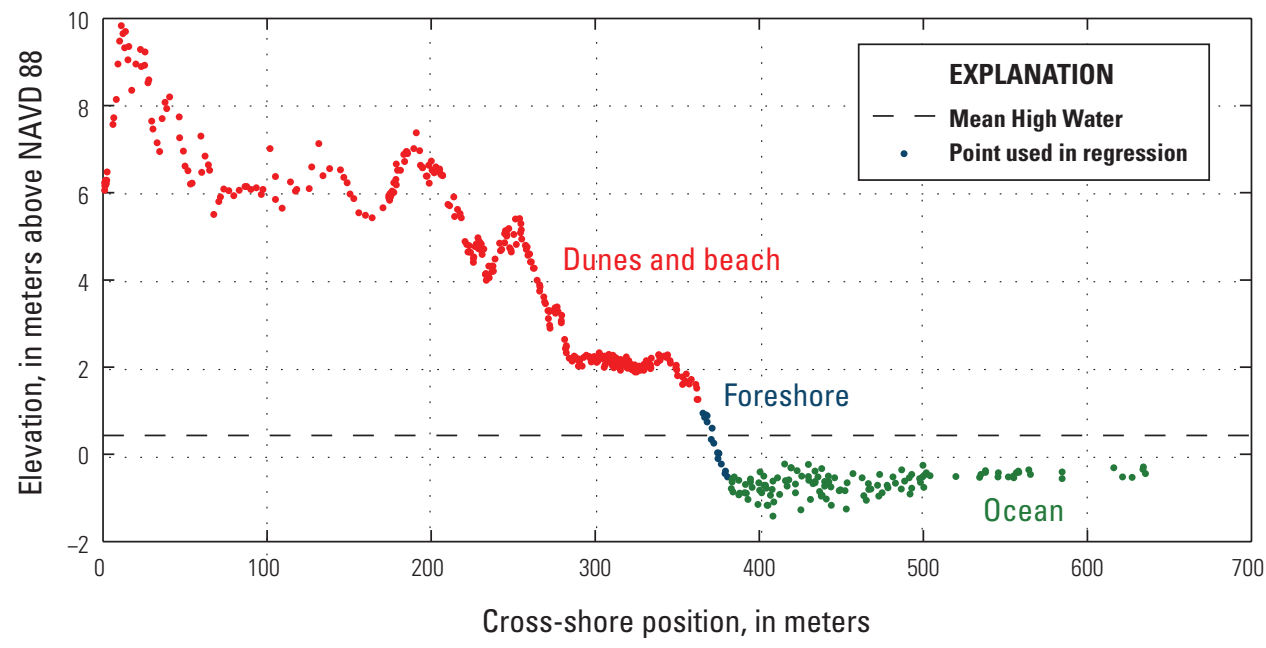

B

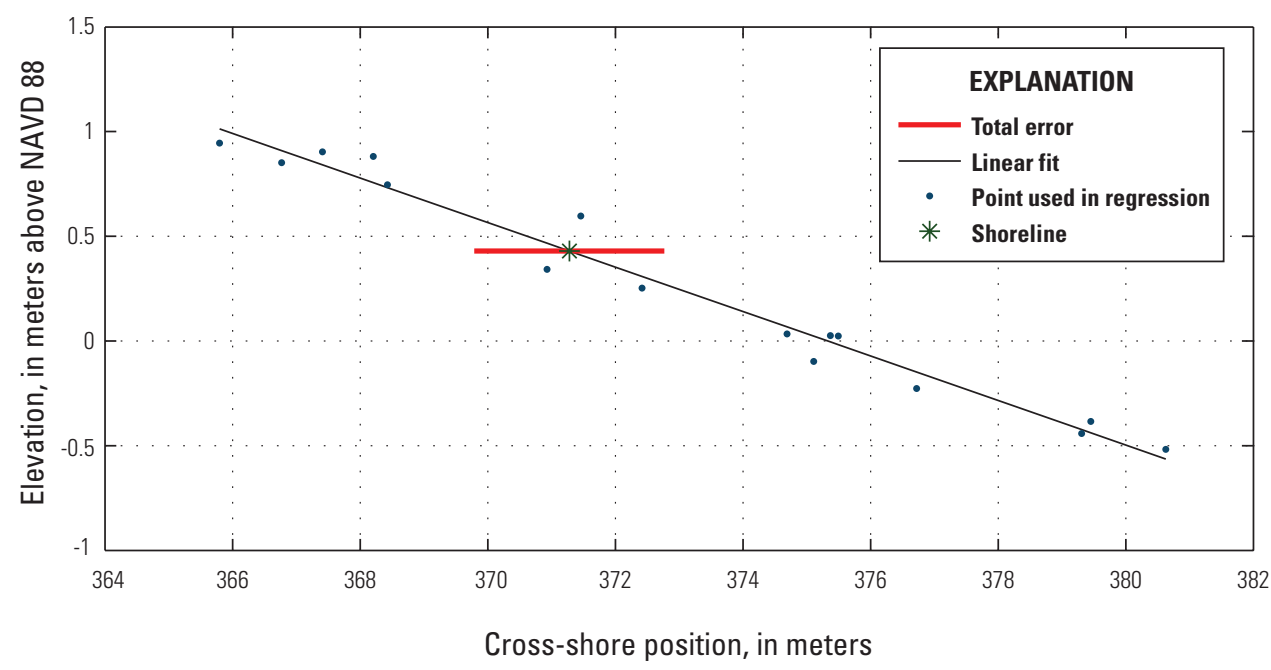

Figure 4. An example of a lidar profile of $A$, the entire cross-shore region and $B$, an expanded view of the foreshore region. $A$, Laser returns off the water's surface are seen as green symbols. Blue symbols indicate data points on the foreshore that were used in the linear regression to find the mean high water (MHW) shoreline. Red symbols indicate data points on the foreshore that were not used in the linear regression as well as points along the rest of the beach and dunes. $B$, Linear regression through the selected foreshore points in $A$ is shown. The asterisk marks the cross-shore position of the operational MHW shoreline. The horizontal error bar represents the total error on the shoreline position. 
Table 3. List of tide gage measurements used to calculate mean high water elevation.

[MHW, mean high water; m, meter; CRLC, Columbia River littoral cell]

\begin{tabular}{llc}
\hline \multicolumn{1}{c}{ Region } & \multicolumn{1}{c}{ Geographic area } & $\begin{array}{c}\text { Average } \\
\text { of } \mathbf{M H W} \\
\mathbf{( m )}\end{array}$ \\
\hline Olympic Coast & Makah (Mukkaw) Bay, Washington & 2.11 \\
CRLC & Westport, Washington & 2.11 \\
CRLC & Columbia River north jetty, Oregon & 2.06 \\
Northern Oregon & Depoe Bay, Oregon & 2.09 \\
Southern Oregon & Cape Arago, Oregon & 2.11 \\
Southern Oregon & Port Orford, Oregon & 1.87 \\
\hline
\end{tabular}

procedure at successive profiles $20 \mathrm{~m}$ apart generates a series of MHW shoreline points than can be connected to produce a continuous shoreline.

Because inland bays are not suitable sites for extraction of a lidar shoreline using the methods employed in this analysis and because this report focuses on the open ocean coasts, shorelines of extensive bay areas, such as Willapa Bay, Grays Harbor, and Tillamook Bay (fig. 2), were not included in the shoreline change analysis. Also, lidar data were not available for all sandy beaches along the PNW coast; gaps exist along much of the northern Olympic Peninsula in Washington.

\section{The Proxy-Datum Bias Correction Between HWL and MHW Shorelines}

Inclusion of a lidar-derived shoreline in coastal change analyses represents a modern approach to the investigation of shoreline change. The pre-lidar historical shorelines used in this study as well as in most shoreline change studies were derived from topographic maps, aerial photographs, or field interpretations that use the HWL as the shoreline proxy. For more than 150 years, the HWL served as the most commonly used shoreline because it could be visually identified in the field (for example, Shalowitz, 1964; Anders and Byrnes, 1991). With advanced technologies, such as GPS and lidar, it is now possible to define the shoreline more objectively on the basis of an elevation or a tidal datum, such as MHW. Changing the shoreline definition from a proxy-based physical feature that is uncontrolled in terms of an elevation datum (HWL) to a datum-based shoreline defined by an elevation contour (MHW) has important implications with regard to inferred changes in shoreline position and calculated rates of change.

Visually identified HWL-type proxy shorelines are virtually never coincident with datum-based MHW-type shorelines. In fact, HWL shorelines are almost universally estimated to be higher (landward) on the beach profile than MHW shorelines (Ruggiero and others, 2003; Morton and others, 2004; Moore and others, 2006). Morton and others
(2004) first compiled published and unpublished data to evaluate the horizontal and vertical differences in HWLs determined from beach profiles, aerial photographs, or GPS surveys, and the MHW derived from beach profiles, GPS surveys, or lidar surveys. Hapke and others (2006) updated the dataset of Morton and others (2004) to include the most recent analyses available (table 4). The HWL and MHW positions were established at the same time or within a few weeks of one another at multiple sites around the United States with diverse beach and wave characteristics. The HWL and MHW positions are compared with the assumption that the observed proxy-datum offsets are entirely artifacts of shoreline definition and are not related to actual changes in the beach profile due to sediment transport (erosion or accretion processes) between the survey dates. This is a relatively safe assumption considering the short intervals between surveys or the knowledge that a particular shoreline segment is relatively stable. Moore and others (2006) avoided the need for this assumption by deriving HWL and MHW shorelines from aerial photography and lidar data collected during the same tidal cycle.

The average absolute horizontal and vertical offsets between the HWL and MHW range from a few meters to more than $50 \mathrm{~m}$, and vertical offsets can be as much as $2 \mathrm{~m}$ (table 4). Most of the horizontal offsets are less than $20 \mathrm{~m}$, and most of the vertical offsets are less than $1 \mathrm{~m}$. Offsets are typically greatest on relatively flat beaches where large waves produce high wave runup (for example, southwestern Washington) and are smallest where beaches are relatively steep and wave runup is low. For the data analyzed by Hapke and others (2006), the percentage of MHW shorelines offset seaward of the HWL exceeded 98 percent within the 17 survey dates. Not accounting for this offset will cause shoreline change rates to be biased toward slower shoreline retreat, progradation rather than retreat, or faster progradation than in reality (for the typical case where datum-based shorelines are collected after proxy-based shorelines), depending on actual changes at a given site.

Recent studies by Moore and others (2006) and Ruggiero and List (2009) illustrate that, overall, the importance of incorporating a proxy-datum offset into shoreline change analysis depends on several factors, including the magnitude of the offset, the length of time over which rates are being measured, and the statistical significance of the shoreline change rates. The proxy-datum offset is particularly important when averaging shoreline change rates alongshore. The offset is a bias that virtually always acts in the same direction; therefore, the error associated with the apparent shoreline change rate shift is not canceled during averaging. It is important to quantify this bias in order to resolve the shift it can cause in reported rates. The shoreline change rates presented in this report have accounted for and incorporated the proxy-datum bias into the rate calculations using the latest version (4.2) of the Digital Shoreline Analysis System (DSAS), an ArcGIS tool developed by the USGS (Thieler and others, 2009). 


\section{National Assessment of Shoreline Change: Historical Shoreline Change Along the Pacific Northwest Coast}

\section{Determination of Proxy-Datum Bias}

This section briefly describes the specific methodology used to determine the proxy-datum bias values as detailed in Ruggiero and List (2009). Comparison of HWL shorelines and a MHW datum-based shoreline for a single-day survey on Assateague Island (Moore and others, 2006) revealed an average horizontal offset between shoreline indicators of $18.8 \mathrm{~m}$ (table 4). Vertical offsets were also substantial and were strongly correlated with foreshore beach slope. A simple total water level model, which combines the effects of tidal variations and wave runup (Ruggiero and others, 2001, 2003), successfully reproduced these vertical offsets, indicating that the proxy-datum offset may be governed primarily by wave runup. To estimate the proxy-datum bias for the PNW region, we use the approach outlined in Ruggiero and List (2009), which includes the wave runup formulation of Stockdon and others (2006). The horizontal offset between HWL and MWH shorelines can be estimated by:

Table 4. Absolute horizontal and vertical differences between high water and mean high water shorelines.

[Modified from Morton and others (2004) and Hapke and others (2006). HWL, high water line; km, kilometer; m, meter; MHW, mean high water; MHWL, mean high-water line]

\begin{tabular}{|c|c|c|c|c|c|c|c|}
\hline \multicolumn{2}{|c|}{ Survey date } & \multirow{2}{*}{$\begin{array}{l}\text { Length } \\
\text { of } \\
\text { shore } \\
(\mathrm{km})\end{array}$} & \multirow{2}{*}{$\begin{array}{c}\text { Number } \\
\text { of } \\
\text { observations }\end{array}$} & \multicolumn{2}{|c|}{$\begin{array}{l}\text { Average offset } \\
(\mathrm{m})\end{array}$} & \multirow{2}{*}{$\begin{array}{c}\text { Percent } \\
\text { MHW } \\
\text { with seaward } \\
\text { offset }\end{array}$} & \multirow{2}{*}{ Data source or reference } \\
\hline HWL & MHWL & & & Horizontal & Vertical & & \\
\hline \multicolumn{8}{|c|}{ Galveston Island, Texas ${ }^{1}$} \\
\hline $01-27-95$ & $01-27-95$ & Point & 1 & 18 & 0.6 & 100 & Morton and Speed, 1998 \\
\hline \multicolumn{8}{|c|}{ North Padre Island, Texas ${ }^{1}$} \\
\hline $08-16-95$ & $08-16-95$ & 1.6 & 6 & 8 & 0.4 & 100 & \\
\hline 09-14-95 & 09-14-95 & 1.6 & 6 & 8 & 0.2 & 100 & \\
\hline $09-28-95$ & 09-28-95 & 1.6 & 6 & 12 & 0.2 & 100 & \\
\hline $10-06-95$ & $10-06-95$ & 1.6 & 6 & 6 & 0.3 & 100 & \\
\hline \multicolumn{8}{|c|}{ Duck, North Carolina² } \\
\hline $1994-1996^{2}$ & $1994-1996^{2}$ & Point & 111 & 40 & 2.0 & 100 & Pajak and Leatherman, 2002 \\
\hline \multicolumn{8}{|c|}{ Klipsan, Washington ${ }^{3}$} \\
\hline $05-26-99$ & 05-28-99 & 3.0 & 171 & 22 & 0.5 & 100 & Ruggiero and others, 2003 \\
\hline 09-21-99 & 09-24-99 & 3.0 & 171 & 52 & 0.8 & 100 & \\
\hline \multicolumn{8}{|c|}{ Ocean Shores, Washington ${ }^{3}$} \\
\hline $05-26-99$ & $05-28-99$ & 4.0 & 200 & 23 & 1.0 & 100 & \\
\hline $07-27-99$ & $07-22-99$ & 4.0 & 200 & 8 & 0.2 & 100 & \\
\hline 05-06-01 & $05-07-01$ & 4.0 & 200 & 30 & 1.0 & 100 & \\
\hline \multicolumn{8}{|c|}{ Oysterville, Washington ${ }^{3}$} \\
\hline 09-21-99 & 09-10-99 & 3.5 & 201 & 49 & 0.9 & 100 & \\
\hline \multicolumn{8}{|c|}{ Assateague Island, Maryland and Virginia ${ }^{4}$} \\
\hline $\begin{array}{c}03-16-98 \text { and } \\
03-17-98\end{array}$ & 04-03-98 & 58.6 & 1,172 & 11 & 0.7 & 99 & National Park Service (M. Duffy) \\
\hline $\begin{array}{c}09-29-99 \text { and } \\
10-28-99\end{array}$ & $10-01-99$ & 60.0 & 1,200 & 20 & 1.6 & 100 & \\
\hline $\begin{array}{c}06-13-01 \text { and } \\
06-14-01\end{array}$ & $06-05-01$ & 52.4 & 1,049 & 8 & 0.6 & 92 & \\
\hline $10-01-02$ & $09-12-02$ & 47.7 & 953 & 22 & 1.4 & 98 & $\begin{array}{l}\text { Coastal Research and Engineering, } \\
\text { Inc. (M. Byrnes) }\end{array}$ \\
\hline 05-06-02 & $05-06-02$ & 47 & 470 & 18.8 & $1.2-1.3$ & 100 & Moore and others, 2006 \\
\hline
\end{tabular}

${ }^{1}$ Simultaneous measurement of HWL and MHW at beach profiles coordinated with tide gage measurements.

${ }^{2}$ Video camera projections of HWL for 111 days during a 3-year period and MHW from generalized beach profiles.

${ }^{3}$ Nearly simultaneous aerial photography (HWL) and Global Positioning System (GPS) (MHW) surveys.

${ }^{4}$ Nearly simultaneous GPS (HWL) and lidar (MHW) surveys. 
Bias $=\left(X_{H W L}-X_{M H W}\right)=\frac{\left[Z_{T}+1.1\left(0.35 \tan \beta\left(H_{o} L_{o}\right)^{(1 / 2)}+\frac{\left[H_{o} L_{o}\left(0.563 \tan \beta^{2}+0.004\right]^{1 / 2}\right.}{2}\right)\right]-Z_{M H W}}{\tan \beta}$,

where

$$
\begin{array}{r}
X_{H W L} \\
X_{M H W} \\
Z_{T} \\
Z_{M H W} \\
\tan \beta
\end{array}
$$$$
H_{o} \quad \text { is the deepwater significant wave height, and }
$$$$
L_{o} \quad \text { is the deepwater wave length given by }
$$$$
\text { linear theory as } g T^{2} / 2 \pi \text {, where } g \text { is the }
$$$$
\text { acceleration due to gravity, and } T \text { is the }
$$$$
\text { peak wave period. }
$$

To calculate the bias, long-term best estimates and measures of uncertainty are derived for beach slope, wave height, wave length, and tide level. The best estimate for beach slope was derived by averaging individual lidar crossshore profile slope estimates within 1-kilometer $(\mathrm{km})$ blocks along the coast. The long-term mean wave height and length are used as the best-estimate values in the bias calculation. The long-term mean wave height is derived from averaging USACE Wave Information Studies (WIS) hindcasts, whereas the long-term mean wave length (computed using linear theory and peak wave period) is averaged from long-term buoy records (National Data Buoy Center (NDBC) and the University of California, San Diego Coastal Data Information Program (CDIP)) along the PNW coast. Finally, the best estimate of the tide level responsible for generating HWL shorelines is taken as the elevation of MHW (table 3; Weber and others, 2005). The proxy-datum bias varies widely alongshore, but averages more than $30 \mathrm{~m}$ through the PNW study area, confirming the importance of accounting for the bias in shoreline change analyses.

\section{Uncertainty in the Proxy-Datum Bias}

Each of the variables in equation 1 has associated uncertainties; therefore, the proxy-datum bias correction also has an uncertainty. The measures of uncertainty for the beach slope, wave height, and wave length are estimated as the difference between the 95-percent and the 50-percent exceedance statistics of the cumulative distribution for each variable. This provides a 90-percent confidence interval (CI) for each of the three cumulative distributions. The uncertainty of assuming that the tide is responsible for producing the HWL shoreline proxy, and that it is about the elevation of MHW, is calculated by subtracting MHW from mean higher high water (MHHW). Using these values of uncertainty for each of the variables in equation 1, the bias uncertainty is calculated using the procedure described in Ruggiero and List (2009).

\section{Use of the Proxy-Datum Bias and Bias Uncertainty in Shoreline Change Analysis}

The proxy-datum bias and bias uncertainty are calculated at each of the 1-km blocks in which the average beach slope has been calculated. Version 4.2 of DSAS incorporates proxy-offset values into proxy-datum bias shifts to reconcile the horizontal offsets between the MHW and HWL shoreline proxies. The operational MHW shoreline points extracted from the lidar data at 20-m alongshore spacing are written to a table containing locations on a Cartesian coordinate system and three associated values: (1) shoreline position uncertainty, (2) the proxy-datum bias, and (3) the proxy-datum bias uncertainty. The proxy-datum bias is incorporated in the shoreline change statistics calculations to correct for datum offsets between the MHW and HWL shorelines (Himmelstoss, 2009), and the uncertainty values are used in the estimation of shoreline change uncertainty (see HWL Shoreline Position Uncertainty section).

\section{Estimation of Shoreline Position Uncertainty}

The uncertainty of calculated rates of shoreline change, $U_{r}$, depends on the total shoreline position uncertainty. Shoreline position uncertainties from sources that can be quantified are described in this section for HWL- and MHW-type shorelines.

A potentially large source of shoreline position uncertainty that is typically not quantified results from the local short-term variability of true shoreline positions due to sediment transport and morphological change (Morton, 1991; Douglas and Crowell, 2000; Ruggiero and others, 2003). Along the PNW coast, as in many locales worldwide, there are pronounced seasonal cycles and storm-event-driven erosion and accretion along the shoreline. This variability is driven by episodic events such as major extratropical cyclones, variations in wave and water level conditions from summer to winter, and particularly interannual climatic variability associated with El Niño (Ruggiero and others, 2005). The PNW is perhaps unique in that mature beach morphology monitoring programs exist along much of the coastline. Scientists in the Washington Department of Ecology (beaches in Washington), Oregon Department of Geology and Mineral Industries (beaches in Oregon), and Oregon State University (beaches in Oregon and Washington) are compiling information on the morphodynamics of beaches along the PNW in order to document the seasonal, interannual, and longterm changes taking place at multiple beach study sites and 
at a range of spatial scales. These data are of broad interest to the public ranging from scientists, coastal resource managers, geotechnical consultants, and the general public. Since 1997, scientists have developed a nested sampling scheme for measuring PNW changes in the morphology of beaches and shorelines. These data include cross-sectional beach surveys, topographic mapping, and bathymetric surveys and are available from the Northwest Association of Networked Ocean Observing Systems at http://nvs.nanoos.org/BeachMapping.

At a national scale, however, reliable high-frequency data regarding short-term variability at most coastal sites are limited. Therefore, the uncertainty values reported for other regions by the National Assessment of Shoreline Change Project do not include an uncertainty term for the seasonal shoreline position variability when quantifying uncertainty associated with the regionally averaged shoreline change rates. To be consistent with earlier efforts, we will not formally include short-term morphological change information in our quantification of shoreline change rate uncertainty in this report.

\section{HWL Shoreline Position Uncertainty}

Anders and Byrnes (1991), Crowell and others (1991), Thieler and Danforth (1994), Moore (2000), and Ruggiero and others (2003) provided general estimates of the typical HWL measurement uncertainties associated with (1) mapping methods and materials for historical shorelines, (2) the registration of shoreline position relative to geographic coordinates, and (3) shoreline digitizing. As in the methods outlined by Crowell and others (1991), we identify five uncertainty terms for HWL-type shorelines: georeferencing uncertainty $\left(U_{g}\right)$, digitizing uncertainty $\left(U_{d}\right)$, T-sheet survey uncertainty $\left(U_{t}\right)$, aerial photograph uncertainty $\left(U_{a}\right)$, and the uncertainty of the HWL at the time of survey, which is calculated as the proxy-datum bias uncertainty $\left(U_{p d}\right)$.

The georeferencing uncertainty represents the elected maximum acceptable RMSE for T-sheets at a scale of 1:20,000 in this study. The georeferencing uncertainty, $\pm 4 \mathrm{~m}$, is applied to the historical shorelines that are derived from $\mathrm{T}$-sheets only (1800s-1970s). The digitizing uncertainty, $\pm 1 \mathrm{~m}$, reflects the maximum error specified in past studies (Anders and Byrnes, 1991; Crowell and others, 1991; Moore, 2000) and is applied to all HWL shorelines. The maximum T-sheet survey uncertainty, determined by Shalowitz (1964), incorporates all the errors associated with the mapping process, including distance to rodded points, plane-table position, and identification of the HWL. The T-sheet survey uncertainty is applied to all historical shorelines; however, the uncertainty associated with the 1970 s-era T-sheets $( \pm 3 \mathrm{~m})$ is considerably less than that associated with the older T-sheets from the 1800 s to the $1950 \mathrm{~s}$ ( $\pm 10 \mathrm{~m}$ ). This difference is based on findings by Ruggiero and others (2003) as well as the fact that more recent shorelines are derived from aerial photographs or other sources. The aerial photography uncertainty, $\pm 3 \mathrm{~m}$, is applied to shoreline positions from the 1960s through 1990s aerial photographs that were digitized as part of this study. A previously unreported uncertainty term in shoreline change analyses is the uncertainty in HWL shorelines due to variations in water levels. The uncertainty of the proxy-datum bias, found using equation 1 and the uncertainty estimation techniques of Taylor (1997), can be shown to be equivalent to the uncertainty of the HWL shoreline due to water-level variations (Ruggiero and List, 2009). The HWL uncertainty varies alongshore as a function of the variables in equation 1 , but averages $\pm 14.8 \mathrm{~m}$ in our study area. For each HWL shoreline position, the total uncertainty is found as the square root of the sum of the squares (Taylor, 1997) of the relevant uncertainty terms based on an assumption that the uncertainty of each term is random and independent of the others. For shorelines derived from the 1800s through 1970s T-sheets, the total shoreline position uncertainty, $U_{p}$, at each transect, $i$, is:

$$
U_{p_{i}}=\sqrt{U_{g_{i}}{ }^{2}+{U_{d_{i}}}^{2}+U_{t_{i}}{ }^{2}+U_{p d_{i}}{ }^{2}},
$$

and the uncertainty associated with the 1967 through 1990s aerial photography is:

$$
U_{p_{i}}=\sqrt{U_{d_{i}}^{2}+U_{a_{i}}^{2}+U_{p d_{i}}^{2}} .
$$

The shoreline position uncertainties calculated from equations 2 and 3 vary alongshore because of a spatially varying $U_{p d}$. Values of $U_{p d}$ are available in Kratzmann and others (2013). For reference, the average values of uncertainty terms and the total average shoreline position uncertainty for each shoreline type are listed in table 5. Note that these average values are not used to determine shoreline change uncertainty (see Estimation of Shoreline Change Rate Uncertainty section).

\section{Lidar-Derived MHW Shoreline Position Uncertainty}

Each MHW lidar shoreline position, derived at a 20-m alongshore spacing, has an associated uncertainty that includes three components. The first is the 95-percent CI associated with the regression estimate in the determination of the linear regression MHW position for each cross-shore profile of lidar point cloud data. The second uncertainty component is the uncertainty associated with the raw lidar data position, especially elevation. Sallenger and others (2003) determined that the vertical accuracy of NASA's ATM lidar system is about $\pm 15 \mathrm{~cm}$, which can be thought of as a bias in lidar elevation (not a random error). This vertical uncertainty is converted to a horizontal shoreline position uncertainty using the beach slope determined by the linear regression. The third component of the total uncertainty is the uncertainty due to extrapolation (the difference between an observed position and a position predicted on a projected regression line). Although the 95-percent CI on MHW position is larger when extrapolation is used, extrapolation assumes that the 
Table 5. Average uncertainties for the Pacific Northwest shorelines.

[DRG, digital raster graphics; m, meters; T-sheet, National Oceanic and Atmospheric Administration topographic sheet; --, not applicable]

\begin{tabular}{|c|c|c|c|c|c|}
\hline \multirow{3}{*}{$\begin{array}{l}\text { Measurement uncertainty } \\
\text { (meters) }\end{array}$} & \multicolumn{5}{|c|}{ Source and dates of data } \\
\hline & \multicolumn{2}{|c|}{ T-sheets } & \multirow{2}{*}{$\begin{array}{c}\text { DRGs, } \\
\text { 1940s-1990s }\end{array}$} & \multirow{2}{*}{$\begin{array}{l}\text { Aerial photography, } \\
1960 \mathrm{~s}-1990 \mathrm{~s}\end{array}$} & \multirow{2}{*}{$\begin{array}{l}\text { Lidar, } \\
2002\end{array}$} \\
\hline & $1800 s-1950 s$ & 1970s & & & \\
\hline Georeferencing $\left(U_{g}\right)$ & 4 & 4 & 4 & -- & -- \\
\hline Digitizing $\left(U_{d}\right)$ & 1 & 1 & 1 & 1 & -- \\
\hline T-sheet survey/DRG $\left(U_{t}\right)$ & 10 & 3 & 15 & -- & -- \\
\hline Aerial photography $\left(U_{a}\right)$ & -- & -- & -- & 3 & -- \\
\hline Uncertainty of high water line $\left(U_{p d}\right)$ & 14.8 & 14.8 & 14.8 & 14.8 & -- \\
\hline Lidar total position uncertainty $\left(U_{p i}\right)$ & -- & -- & -- & -- & 4.1 \\
\hline Total shoreline position uncertainty $\left(U_{p i}\right)$ & 18.3 & 15.7 & 21.4 & 15.1 & 4.1 \\
\hline
\end{tabular}

foreshore slope is constant from the limit of the lidar data to the position of MHW. Because this may not be the case, we calculate an additional MHW uncertainty term by assuming a certain degree of cross-shore slope variability and finding the corresponding variability in extrapolated MHW position. The slope variability was found through an extensive compilation of foreshore slope variability extracted from more than 1,200 km of coastal lidar data from the PNW, Northeast, and Mid-Atlantic regions of the United States. The three uncertainty terms are then added using the square root of the sum of the squares to give the $U_{p_{i}}$ for the MHW shoreline at each lidar profile. This total uncertainty for MHW shorelines varies alongshore on a profile-by-profile basis, with the PNW average value of $\pm 4.1 \mathrm{~m}$ (table 5 ).

\section{Calculation and Interpretation of Shoreline Change Rates}

Rates of long-term shoreline change at each transect were generated using the linear-regression method provided by DSAS version 4.2. For this study, DSAS is used to generate orthogonal transects at $50-\mathrm{m}$ spacing along the coast and to subsequently calculate change statistics (linear regression rate and end-point rate). Information derived from lidar data at a 20-m alongshore spacing, including MHW shoreline positions, the proxy-datum bias, and the proxy-datum bias uncertainty, is interpolated onto the 50-m DSAS transect spacing. Linear regression is the most commonly applied statistical technique for expressing shoreline movement and estimating rates of change (Crowell and Leatherman, 1999) where there are a statistically valid number of samples. However, linear regression fails to recognize the potential for temporal differences in trend (trend reversals) and accelerations or decelerations (Morton, 1991, 1996; Fenster and others, 1993; Fenster and Dolan, 1994), so average trends and rates of shoreline change in this study were calculated for long- (entire period) and short-term (most recent) time scales to capture potential changes in shoreline change rates or trends.

\section{End-Point (Short-Term) Rates}

Short-term rates of shoreline change were calculated at each transect using an end-point rate between a shoreline position for 1967 through 1988 (except in the Olympic Peninsula region where an additional short-term rate was computed using a 1920s-era shoreline due to gaps in other data) and the most recent shoreline (2002) to provide an approximately 15 - to 35-year (80-year for the Olympic Peninsula) short-term rate (tables 1 and 2). The end-point rate is calculated as the difference in shoreline position between the two shoreline years divided by the time between surveys. The proxy-datum bias was applied to remove the bias between the HWL and MHW shorelines by adjusting the horizontal position of the MHW shoreline before rates were calculated. For an end-point rate, there is no assumption that the rate was linear between the two survey years; the rate represents the net change between the surveys, annualized to facilitate comparisons with long-term rates found through linear regression, described in the Linear Regression (Long-Term) Rates section.

\section{Linear Regression (Long-Term) Rates}

Long-term rates of shoreline change were calculated at each transect as the slope of the linear regression through all shoreline positions from the earliest (1800s) to the most recent (the lidar-derived shoreline). The proxy-datum bias was used to adjust the position of the MHW shoreline prior to rate calculation in order to remove the bias between the HWL and MHW methods of delineating shoreline position.

A minimum of four shoreline positions through time at each DSAS transect was required for the calculation of longterm rates of change. One of the shorelines must be the lidarsurveyed shoreline. Fewer than four shorelines can result from one or more of the following conditions: (1) the position of an inlet or stream mouth has changed or migrated, (2) shoreline segments are missing (data gaps), (3) a coastal structure 
eliminated one or more of the shorelines, and (4) no lidarderived shoreline is available for rocky coasts. Table 2 lists the shoreline dates and sources used for the linear regression in each region; the dates that cover specific coastal locations can be found in Kratzmann and others (2013).

The linear regression method of determining shoreline change rates does assume a linear trend of change between the earliest and latest shoreline dates. However, there are clearly areas where such a linear trend does not exist - that is, shoreline change rates have not remained constant through time. In these cases, it is expected that the resulting linear fit to the data would be poorer and the shoreline change rate uncertainty, $U_{R}$, described in the Estimation of Shoreline Change Rate Uncertainty section, would be relatively high.

\section{Estimation of Shoreline Change Rate Uncertainty}

\section{Rate Uncertainty at Individual Transects}

The uncertainty of the end-point (short-term) shoreline change rate of a single transect is calculated as the quadrature addition of the uncertainties for each year's shoreline position divided by the number of years between the shoreline surveys:

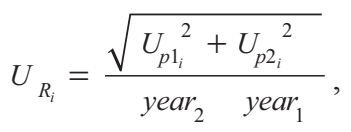

where

$$
\begin{gathered}
U_{p 1_{i}} \text { and } U_{p 2_{i}} \text { are the shoreline position uncertainties of the } \\
\text { first (year }) \text { and second (year }{ }_{2} \text { ) shorelines, } \\
\text { respectively, at transect } i \text {, calculated } \\
\text { through equation } 2 \text { or } 3 .
\end{gathered}
$$

For the linear regression method (long-term), the uncertainty of the rate of shoreline change of a single transect, $U_{R}$, is found here as the 90 -percent $\mathrm{CI}$ on the linear regression slope.

\section{Regionally Averaged Rate Uncertainty}

In addition to shoreline change rates and rate uncertainties at individual transects, this report provides regionally averaged shoreline change rates, $\bar{R}$, and the associated average rate uncertainty, as a measure of broader scale trends. The procedure for finding the uncertainty associated with regionally averaged shoreline change rates, described below, is the same for both the end-point and linear regression methods.

A common method for finding the uncertainty on a mean value is based on variations in the measurement values themselves, typically using a t-distribution CI on the mean of a limited sample from a population calculated as:

$$
C_{t}= \pm t \quad \alpha(2), v S_{\bar{x}}
$$

where

$$
\begin{gathered}
t_{\alpha(2), v} \quad \text { is the two-tailed t-distribution value in } \alpha \\
\text { which is the confidence level and } v \text { is the } \\
\text { degrees of freedom, and } \\
s_{\bar{x}} \quad \text { is the standard error on the sample mean } \\
\text { and is calculated as } s / \sqrt{n} \text {, where } \mathrm{s} \text { is the } \\
\text { standard deviation of the sample and } n \text { is } \\
\text { the sample size. }
\end{gathered}
$$

The regionally averaged rates of change presented in this report, however, are not a limited sample from a larger population as assumed in equation 5. The mean shoreline change for a region is essentially a measure of the whole population, given the 50-m spacing of the DSAS transects. Therefore, the uncertainty associated with regional variations in shoreline change rate is negligible. However, a much larger source of uncertainty arises from the uncertainty of each individual shoreline change value used in the mean. The values of the rate of shoreline change, $R_{i}$, for each transect has an uncertainty, $U_{R_{i}}$, that can be used to estimate the uncertainty of the regionally averaged shoreline change, $\bar{R}$.

Given that the regionally averaged shoreline change rate is calculate as:

$$
\bar{R}=\frac{1}{n} \sum_{i}^{n} R_{i}
$$

where $\mathrm{n}$ is the number of transects within the region, the simplest method of finding the associated uncertainty is:

$$
\bar{U}_{R}=\frac{1}{n} \sum_{i}^{n} U_{R_{i}},
$$

However, in this method it is assumed that there is no advantage in having multiple transects- that is, there is no cancellation of uncertainties between transects due to random variability. Shoreline change rate uncertainties calculated with equation 7 are, in most cases, larger than the regionally averaged shoreline change rate calculated by equation 6 . We consider equation 7 to result in an overestimate of the uncertainty because some cancellation of uncertainties is likely in a regional analysis.

An alternative method of estimating uncertainty can be applied if we assume that the uncertainty for each transect is random and independent of all the other transects. In this case the uncertainty associated with regionally averaged shoreline change rates can be calculated as:

$$
U_{R_{q}}=\frac{1}{n} \sqrt{\sum_{i}^{n} U_{R_{i}}{ }^{2}},
$$

which represents a quadrature average of uncertainties, following Taylor (1997). Quadrature average results in very small values of uncertainty, on the order of \pm 1 to $2 \mathrm{~cm}$ and is likely an underestimate of the uncertainty because it is unlikely that all transect uncertainties are independent of all the others. 
A better estimate of the regionally averaged shoreline change rate uncertainty likely falls between the extremes of equations 7 and 8, whereby each transect rate uncertainty is partially independent of the others. To estimate the regionally averaged uncertainty of partially independent transect rates, we first evaluate the effective number of independent uncertainty values, $n *$. Following Garrett and Toulany (1981), we find $n^{*}$ based on the spatially lagged autocorrelation of $U_{R_{i}}$. In all regions, this method results in a large reduction in the original sample size, $n$.

Substitution of $n *$ into equation 8 is not possible without knowledge of which values of $U_{R_{i}}$ represent the independent samples. Using $n *$ in the denominator of equation 8 while finding the quadrature sum of all the values of $U_{R_{i}}$ in the numerator gives a much larger uncertainty than the uncertainty calculated using equation 7 . We use a simplified version of equation 8 to find an average rate uncertainty which accounts for the reduced effective sample size, $n^{*}$. When all $U_{R_{i}}$ values are equal, the right-hand side of equation 8 reduces to $\bar{U}_{R} / \sqrt{n}$. Assuming that the $U_{R_{i}}$ of a region can be represented by $\bar{U}_{R}$, we calculate the uncertainty of a regionally averaged change rate as:

$$
\bar{U}_{R_{q^{*}}}=\frac{1}{\sqrt{n^{*}}} \bar{U}_{R},
$$

Unlike Hapke and others (2011), we calculate $n *$ for a combined all PNW dataset by summing the $n^{*}$ values for individual regions rather than calculating $n^{*}$ for the all-region data as a whole. Uncertainty values calculated using equation 9 are generally much smaller than the arithmetic mean CI calculated from equation 7 , but larger than the quadrature-averaged CI calculated from equation 8 .

\section{Human Beach Alterations That Influence Rates of Change}

Differentiating between natural rates of erosion and the influences of engineering structures is difficult because few studies have been conducted to address these issues specifically. In addition, available data may be inadequate to address these questions because the number of available shoreline positions immediately before, after, and between structure emplacement is insufficient. Human responses to shoreline erosion are included in the discussion of the results of the shoreline change analysis where possible.

In the PNW, the construction of jetties to aid navigation has had the greatest influence on shoreline change rates (for example, Kaminsky and others, 2010). To some extent, particularly at the mouth of the Columbia River, sand volume transfers have been mechanically enhanced through channel dredging and offshore disposal. In recent decades, offshore disposal of dredged sand from the Columbia River entrance has reduced the littoral sediment budget and contributed to erosion of the inner delta and adjacent coasts. Additionally, dams and irrigation have reduced river flows and sand supply from the Columbia River, the primary source of Columbia River littoral cell sediment during the historical period. Unlike other parts of the United States, beach nourishment has historically been a seldom-used practice in the PNW.

\section{Geology and Geomorphology of the Pacific Northwest Coast}

The coasts of Oregon and Washington are some of the most dynamic coastal landscapes in North America, evident by long sandy beaches, sheer coastal cliffs, dramatic headlands and vistas, and ultimately the power of the Pacific Ocean that serves to erode and change the geomorphology of the coast.

\section{Geologic Setting}

The coast of the PNW is tectonically active, being a collisional coast in the classification by Inman and Nordstrom (1971), referred to as the Cascadia subduction zone (CSZ). The oceanic Juan de Fuca and Gorda plates are moving northeasterly at a relative rate of about 4 centimeters per year $(\mathrm{cm} / \mathrm{yr})$, colliding with and being subducted beneath the continental North American plate (fig. 5). The most recent subduction earthquake occurred on January 26, 1700, when an estimated magnitude 9 earthquake generated a catastrophic tsunami that swept across this coast (Atwater, 1987; Atwater and Hemphill-Haley, 1997; Satake and others, 2003; Witter and others, 2003; Kelsey and others, 2005; Nelson and others, 2006). Geologic investigations of sequences of buried marshes and tsunami sands documented the occurrences of multiple subduction zone earthquakes and tsunamis spanning thousands of years, with an average recurrence interval of 300 to 500 years. However, recent studies suggest that subduction earthquakes have been more frequent at the lower latitudes of southern Oregon and northern California, with longer periods between events at the higher latitudes of northern Oregon and Washington, caused by partial ruptures of the subduction zone (Goldfinger and others, 2012).

Nearly all of Oregon and Washington was created by the accretion to the continent of oceanic sediments and a series of volcanic island arcs similar to the present-day Aleutian Islands (Komar, 1997). The Blue Mountains in eastern Oregon are thought to have been added to the continent during the late Triassic and Cretaceous periods - the age of dinosaurs, 150 to 250 million years ago. Before that, the area now known as the PNW was part of a deep ocean basin. The oldest rocks found in the Coast Range of western Washington and Oregon are oceanic basalts and date to the Paleocene and Eocene epochs, about 40 to 60 million years ago. During this period, strong volcanic activity created a series of islands that eventually 


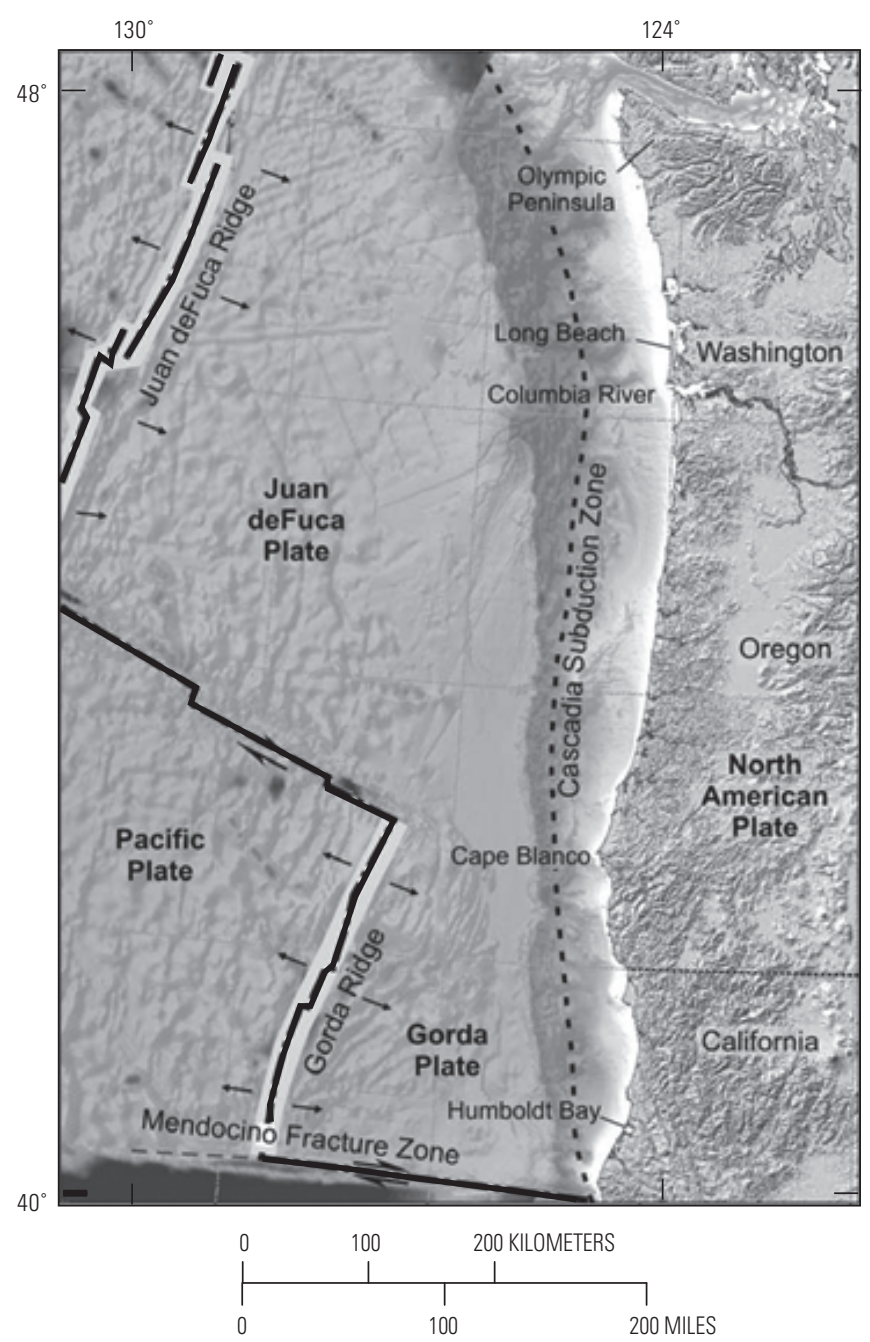

Figure 5. Shaded relief map showing the tectonic setting of the Pacific Northwest, with the collision and subduction of the oceanic plates beneath the continental North American plate; from Komar, Allan, and Ruggiero (2011).

accreted to the continent and are now a series of north-south peaks in the Coast Range.

During the late Miocene, about 15 million years ago, the Columbia River basalts provided the resistant basalt layers that form several of the major headlands in the region (fig. 6) features that are particularly important to the geomorphology of the modern coast.

The Coast Range, the Willamette Valley of Oregon, and the Puget Lowland of Washington (fig. 2) were once underwater and part of a large embayment that persisted until the Pliocene epoch about 5 million years ago (Komar, 1997). At that time, the Coast Range began to emerge from the sea, forming the land of western Oregon and Washington. Therefore, the PNW coast can be thought of as being geologically very young. With the land's emergence from the sea during the Pliocene, erosion processes began. Weaker rocks were cut away leaving the more resistant rocks of the Coast Range and the basaltic headlands along the coast. The modern coastal geomorphology of the PNW is the product of this erosion that has been occurring for the past 5 million years.

During the Pleistocene and Holocene, roughly the past 2.5 million years, the advance and retreat of glaciers had only an indirect effect on the outer coasts of Oregon and Washington because the glaciers did not actually reach the coast. During high stands of sea level, wave-induced erosion created marine terraces. Tectonic activity uplifted these terraces, and some terraces can now be found in the Coast Range, including, in some locations, stairways of terraces. During the last glacial maximum, about 20,000 years ago, the sea level was about $130 \mathrm{~m}$ lower than it is today, and the shoreline in some places was $50 \mathrm{~km}$ seaward of its current position. As the glaciers melted, sea level rose relatively rapidly until about 6,000 years ago. At that time the rate slowed until about 2,000 years ago when it reached a level fairly close to where it is today.

\section{Coastal Processes}

\section{Waves}

The wave climate of the PNW is recognized for its severity, with winter storms commonly generating deepwater significant wave heights $(\mathrm{SWH})$ greater than $10 \mathrm{~m}$ (about one event of this magnitude per year), with the largest storms in the region having generated SWHs in the range of 14 to $15 \mathrm{~m}$ (Allan and Komar, 2002). Deep-water SWHs and spectral peak periods have annual averages of about $2 \mathrm{~m}$ and 10 seconds (s), respectively. High, long-period waves (averaging about $3 \mathrm{~m}$ in height and 12 to $13 \mathrm{~s}$ in period), high water levels, and a west-southwest direction of wave approach characterize the winter months (November through February), whereas small waves (1-m SWHs and 8-s periods), low water levels, and wind and waves from the west-northwest are the typical summer (May through August) conditions (fig. 7; Ruggiero and others, 2005).

With latitudes ranging from $42^{\circ}$ to greater than $48^{\circ}$ north (fig. 1), the coast of the PNW lies in the path of extratropical storms that cross the North Pacific. The strongest storms develop during the winter, with winds at times achieving hurricane speeds. The cyclonic pattern of the winds and pressures of an individual storm can span such a large area that nearly the entire length of the PNW shore can be affected. The March 2-3, 1999, storm that generated 14- to 15-m SWHs, which developed into a meteorological bomb when it was in close proximity to the coast, is the storm of record (Allan and Komar, 2002).

Increasing wave heights have been observed in the northeastern Pacific using instrumented NOAA buoys along the U.S. West Coast (Allan and Komar, 2000, 2006; Méndez and others, 2006; Menéndez and others, 2008; Komar and others, 2009; Ruggiero and others, 2010; Seymour, 2011) and 


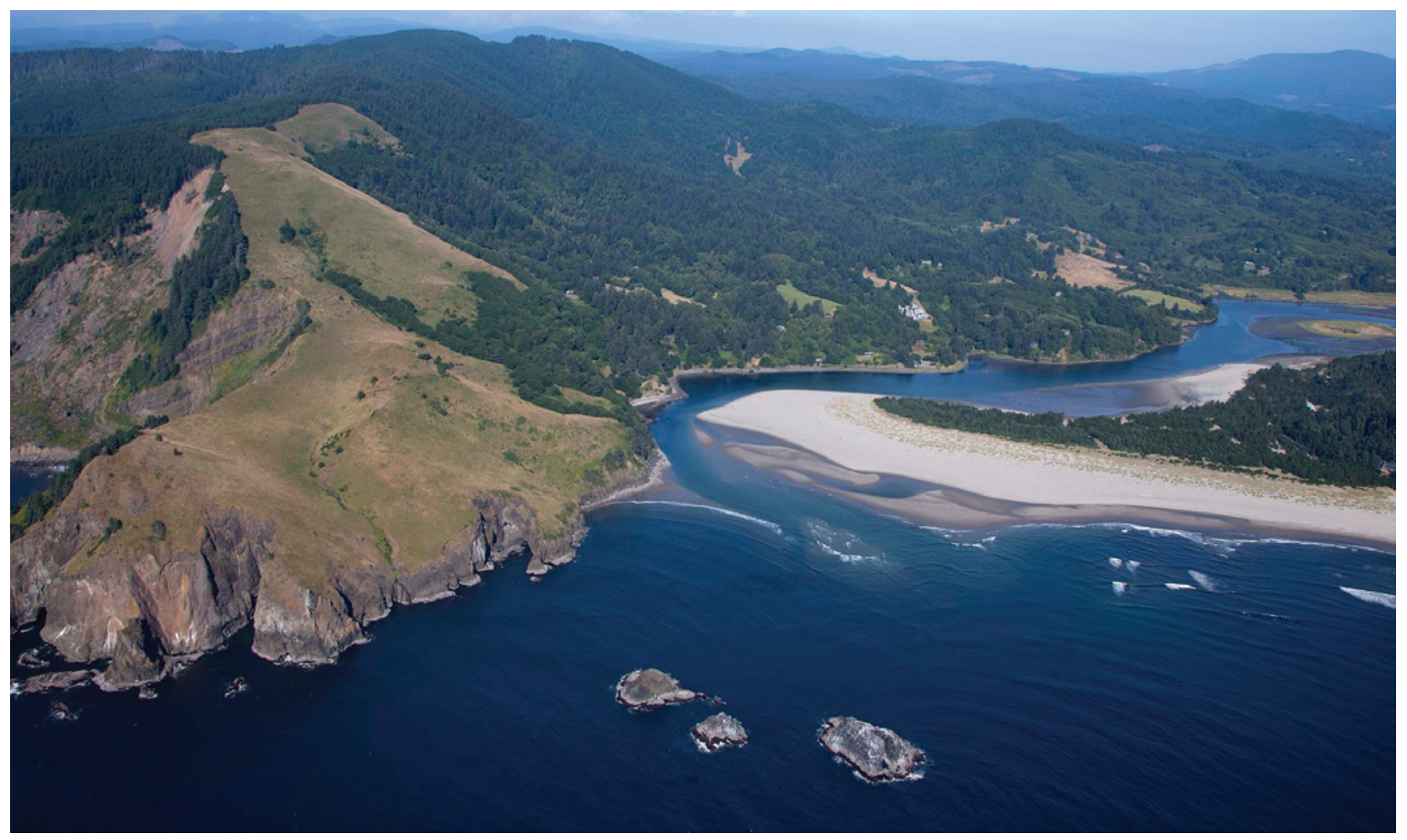

Figure 6. Cascade Head, Oregon, an example of a major Pacific Northwest headland formed by Miocene era Columbia River basalts and the Salmon River Estuary. Photograph by Erica Harris, Oregon Department of Geology and Mineral Industries.

from satellite altimetry (Young and others, 2011). Analyses of North Pacific extratropical storms have concluded that storm intensities (wind velocities and atmospheric pressures) have increased since the late 1940s (Graham and Diaz, 2001; Favre and Gershunov, 2006), implying that the trends of increasing wave heights perhaps began in the mid-20th century, before the availability of direct buoy measurement.

Studies relying solely on buoy measurements, however, have recently been called into question because of concerns over measurement hardware and analysis procedures (Gemmrich and others, 2011). Subsequent analysis that accounts for the modifications of the wave measurement hardware and inhomogeneities in the records reveals trends that are smaller than those obtained from the uncorrected data. The most significant of the inhomogeneities in the buoy records occurred before the mid-1980s. Menéndez and others (2008) analyzed extreme significant wave heights along the eastern North Pacific using datasets from 26 buoys during 1985 through 2007, not including the more suspect data from earlier in the buoy records. Their work revealed significant positive long-term trends in extreme heights off the West Coast between $30^{\circ}$ to $45^{\circ}$ north latitude. Ruggiero (2013) recently showed that, since the early 1980 s, the increases in deep-water wave heights and periods have been more responsible for increasing the frequency of coastal erosion and flooding events along the PNW coast than changes in sea level.

Research on trends in midlatitude extratropical storms in the eastern North Pacific have confirmed that there has been an increase in intensity, but have documented a decrease in frequency, possibly because the storm tracks have shifted poleward during the latter half of the 20th century. McCabe and others (2001) showed a statistically significant decrease in the frequency of storms during 1959 through 1997. However, Geng and Sugi (2003) found that, although the annual number of weak- to medium-strength storms has decreased, stronger storms have actually increased in frequency. These documented changes in storm tracks are thought to be primarily due to changes in baroclinicity, which in turn is linked to changes in atmospheric temperature distributions due to increased greenhouse gas emissions. In other words, in the midlatitudes of the Northern Hemisphere, a decrease in the meridional temperature gradient (poles are warming faster than lower latitudes) has led to a decrease in storm frequency. Recognizing the trends in reanalysis data, Yin (2005) used the output of 15 coupled general circulation models to relate the poleward shift of the storm track to changes in baroclinicity in the 21 st century. Though these studies were able to conclude that the storm track shifts poleward in the Northern Hemisphere with warmer temperatures, uncertainties regarding natural variability and model limitations remain. 

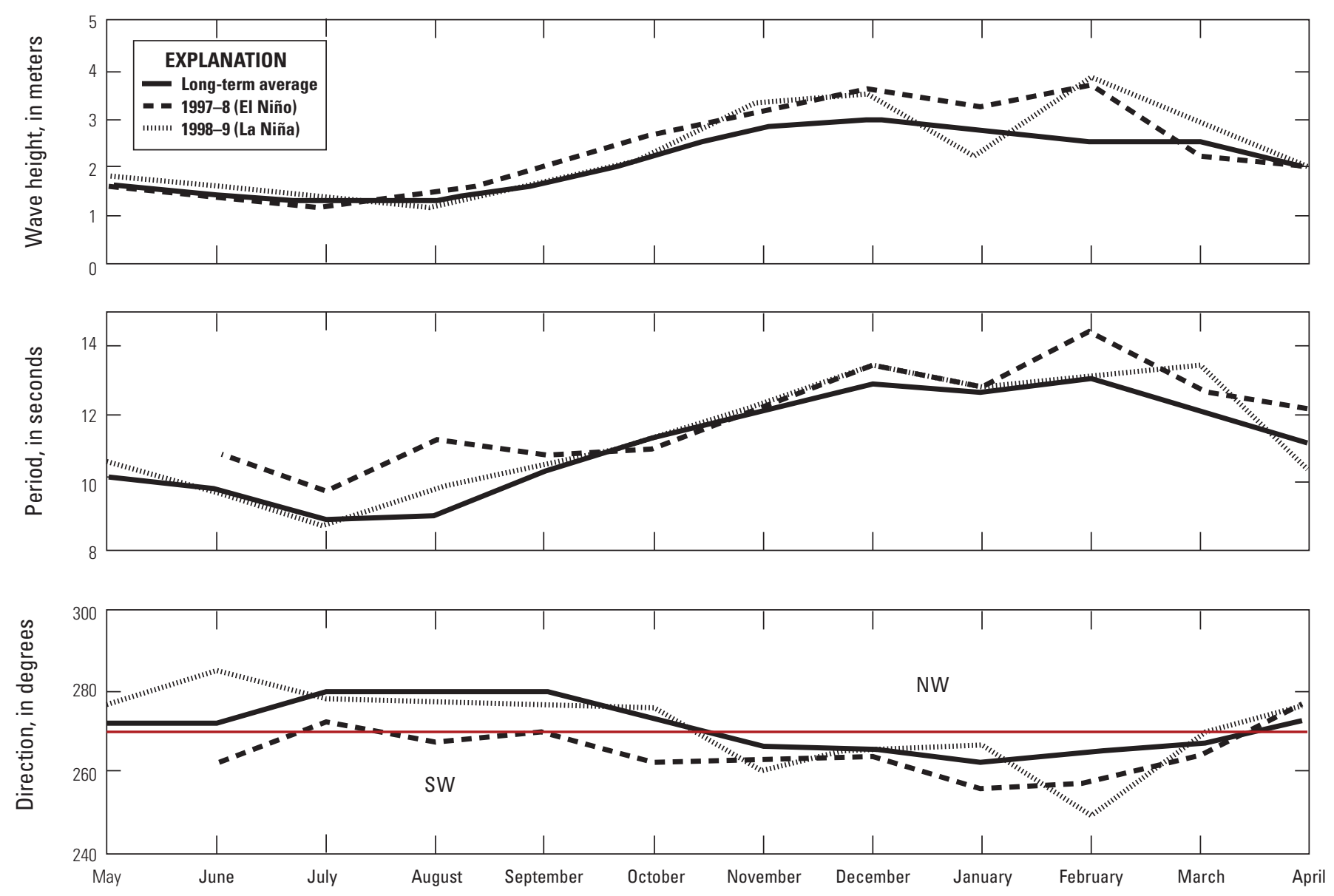

Figure 7. Monthly mean, $A$, significant wave height, $B$, period, and direction, $C$, from the University of California, San Diego Coastal Data Information Program buoy 036 at Grays Harbor, Washington. The solid line represents long-term means beginning in 1981 for wave heights and periods and 1993 for wave direction. Monthly means from the 1997-8 El Niño (dashed line) and 1998-9 La Niña (dash-dot line) are also shown. The red solid line in $C$ represents waves arriving at the coast from due west. NW, northwest; SW, southwest.

\section{Water Levels}

Tides along the outer PNW coast are mixed semidiurnal with a 2- to 4-m mesotidal tidal range. Water levels also have a distinct seasonal cycle (fig. 8), generally due to monthto-month variations in water temperature and, to a smaller degree, salinity. The highest water levels occur during the winter, (December-February) when monthly mean water levels exceed astronomical deterministic tides by about $0.1 \mathrm{~m}$. There are multiple processes that account for this seasonal variation and the fact that the maximum water elevations occur during the winter rather than in the summer as found on most other coasts. Most important in bringing about this inverse relationship on the PNW coast is the occurrence of upwelling during the summer. Seasonal changes in upwelling are initiated by fluctuations in the orientation and magnitude of the shelf currents, which typically flow toward the south in the summer and to the north in the winter. In the summer there is an offshore-directed component to the southerly flow as it turns toward the right due to the effects of the Coriolis force (the Earth's rotation). The water moving offshore is replaced by water upwelled from deep below the surface. Upwelling introduces cold, deep-ocean water onto the shallow continental shelf, thus reducing the mean water level in the summer due to the relatively high density of the fluid. In contrast, during the winter, the shelf current primarily flows toward the north in response to the prevailing seasonal winds, resulting in a deflection of the current toward the coast (to the right) due to Coriolis forces that serves to raise water levels along the PNW coast.

Strong El Niño events feature an increased frequency of storms tracking from the south-southwest and higher than typical sea levels (Komar, 1986; Kaminsky and others, 1998; Komar and others, 2000). During the 1982-3 and 1997-8 El Niño years, PNW beaches experienced monthly mean water levels up to $0.4 \mathrm{~m}$ higher than typical (fig. 8), monthly mean winter wave heights up to $1.0 \mathrm{~m}$ higher than usual (fig. 7), and wave directions having a more southwesterly approach 


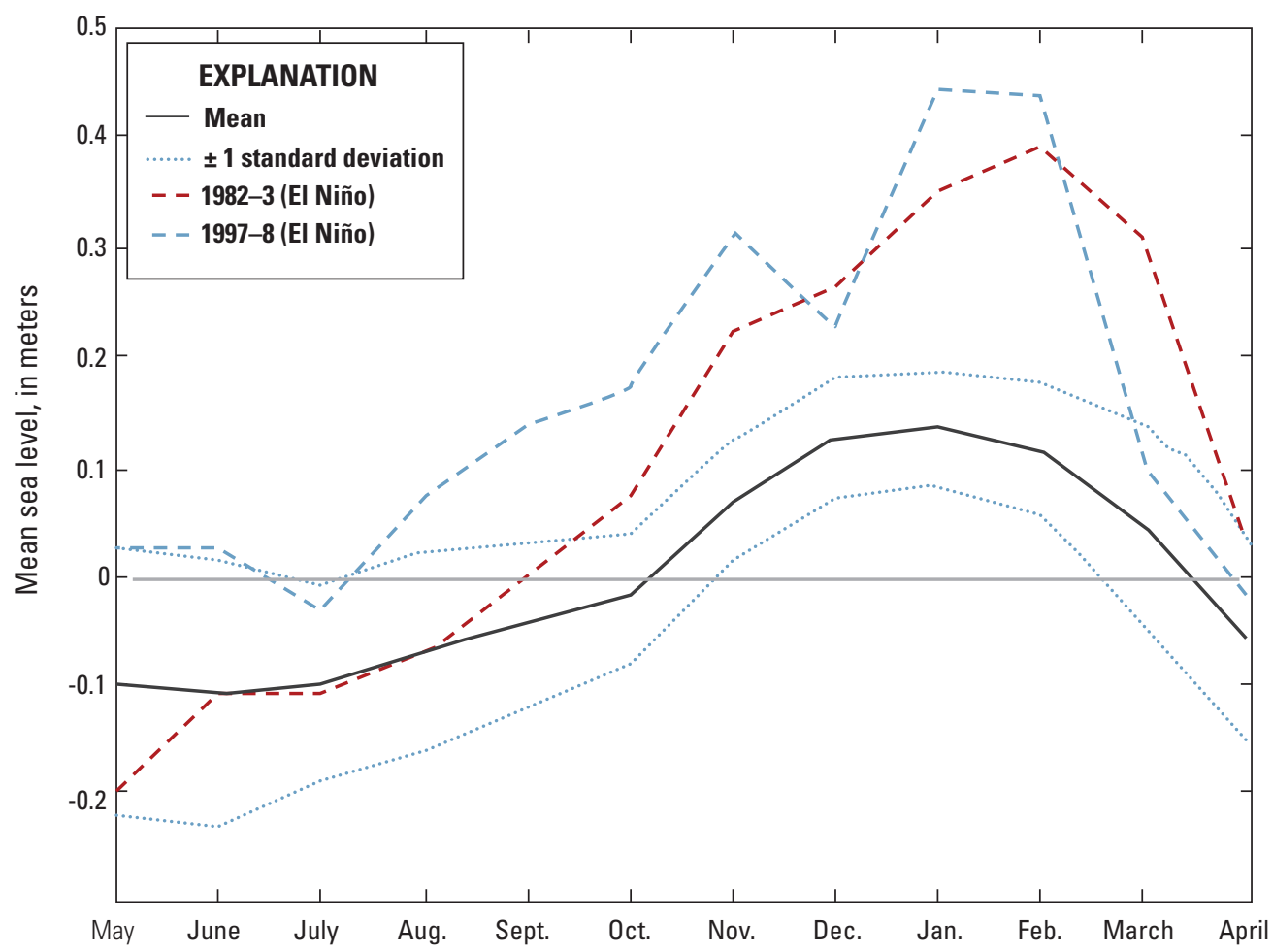

Figure 8. Seasonal variability in the monthly mean water levels derived from analyses of the Yaquina Bay, Oregon, tide-gage data, including the long-term averages and the ranges for the 1982-3 and 1997-8 El Niño years; adapted from Komar and others (2011).

(Kaminsky and others, 1998; Komar and others, 2000; Revell and others, 2002; Barnard and others, 2011). Although monthly mean water levels and wave directions were closer to typical during the 1998-9 La Niña, this event brought an increased number of storms to the region, with higher wave conditions and storm surges than previously experienced (Allan and Komar, 2002). These changes in environmental conditions due to interannual climatic variability have a distinct morphological effect on PNW beaches (see Littoral Cells, Sediment Sources, and Transport section).

Assessments of the trends and variations in long-term historical sea levels are important to investigations of coastal change hazards along the coast of the PNW (Komar and others, 2011, 2013). The tide gage records in this region are strongly affected by tectonics with significant alongshore variations in land-elevation changes. Although some stretches of the coast are being submerged by the net rise in relative sea level, other areas are presently experiencing uplift at rates faster than the increase in sea level, resulting in an emergent coast. Trends of relative sea level rise evaluated from tide gage records range from -1.89 millimeters per year $(\mathrm{mm} / \mathrm{yr})$ on the emergent shore of Neah Bay on the northern coast of Washington to the submergent shore along the north-central Oregon coast, with a relative sea level rise of $1.33 \mathrm{~mm} / \mathrm{yr}$ determined from the Yaquina Bay tide gage (figs. 2 and 9). Another stretch of emergent coast exists south of Coos Bay to Crescent City, California, where the rate of decreasing relative sea level is $-1.10 \mathrm{~mm} / \mathrm{yr}$. The highest rate of increasing relative sea level $(5.3 \mathrm{~mm} / \mathrm{yr})$ is at Humboldt Bay in northern California, which is the southern boundary of the CSZ and outside the shoreline change analysis region of this report (fig. 9); Humboldt Bay is the only area along the coastline of this region where land elevations are decreasing as stress accumulates between the locked tectonic plates. These alongshore variations in the direction and magnitude of relative sea levels are in reasonable agreement with the data for land-elevation changes along this coast (determined using measurements derived from benchmark surveys analyzed by Burgette and others (2009)) and real-time GPS measurements close to the coast. These datasets combined (fig. 10) document the latitudinal variations in relative sea level (Komar and others, 2011). If the projections of accelerated rates of sealevel rise are accurate, then the eustatic (global) rise can be expected to exceed the tectonic uplift later in the 21 st century. This shift in relative sea level will directly affect the coastal zone and may result in sections of the coast experiencing erosion where it is now minor to nonexistent (Ruggiero, 2013). 

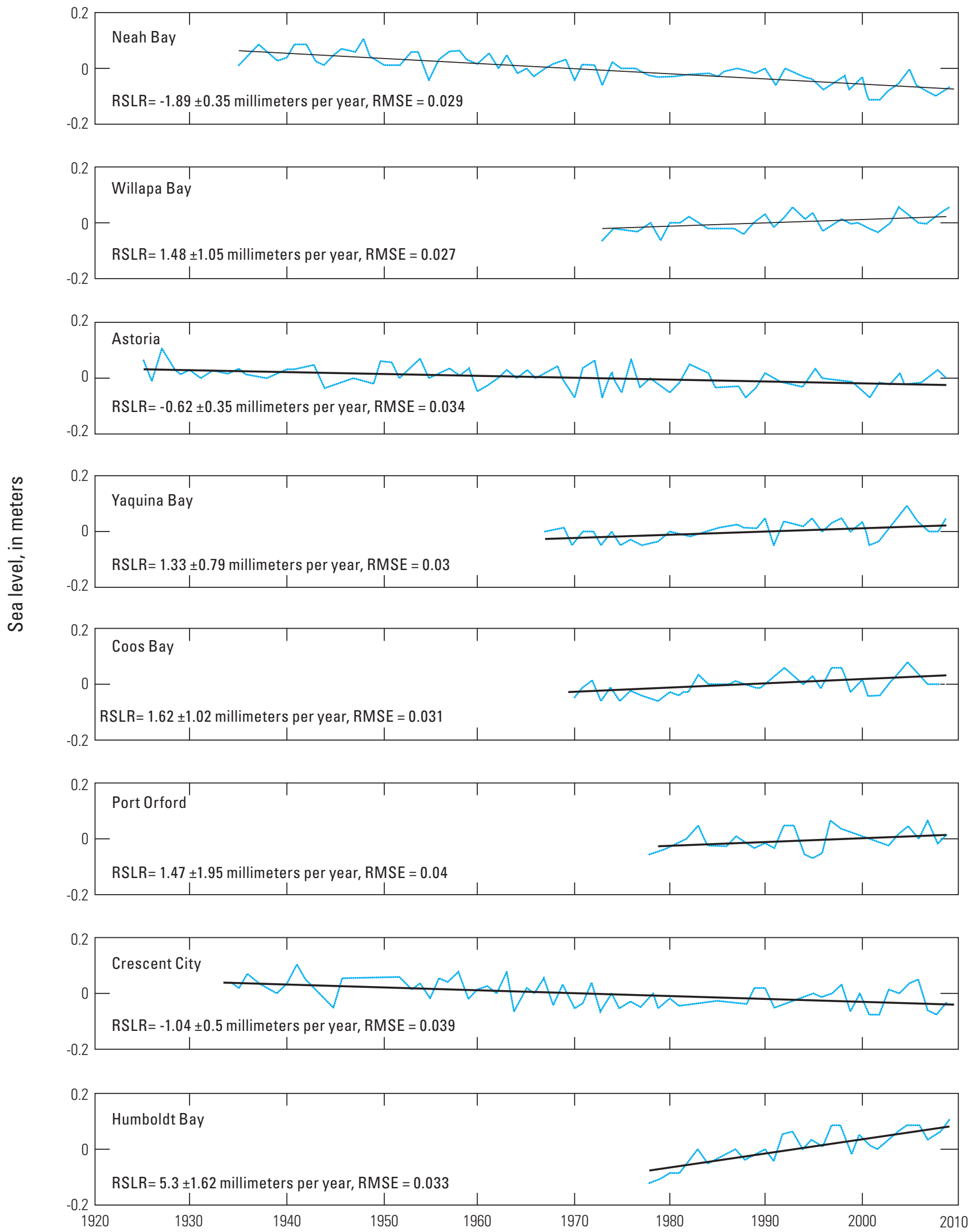

Figure 9. Trends and variations in summer relative sea levels for the Pacific Northwest tide gage records. RMSE, root mean square error; RSLR, relative sea level rise. 


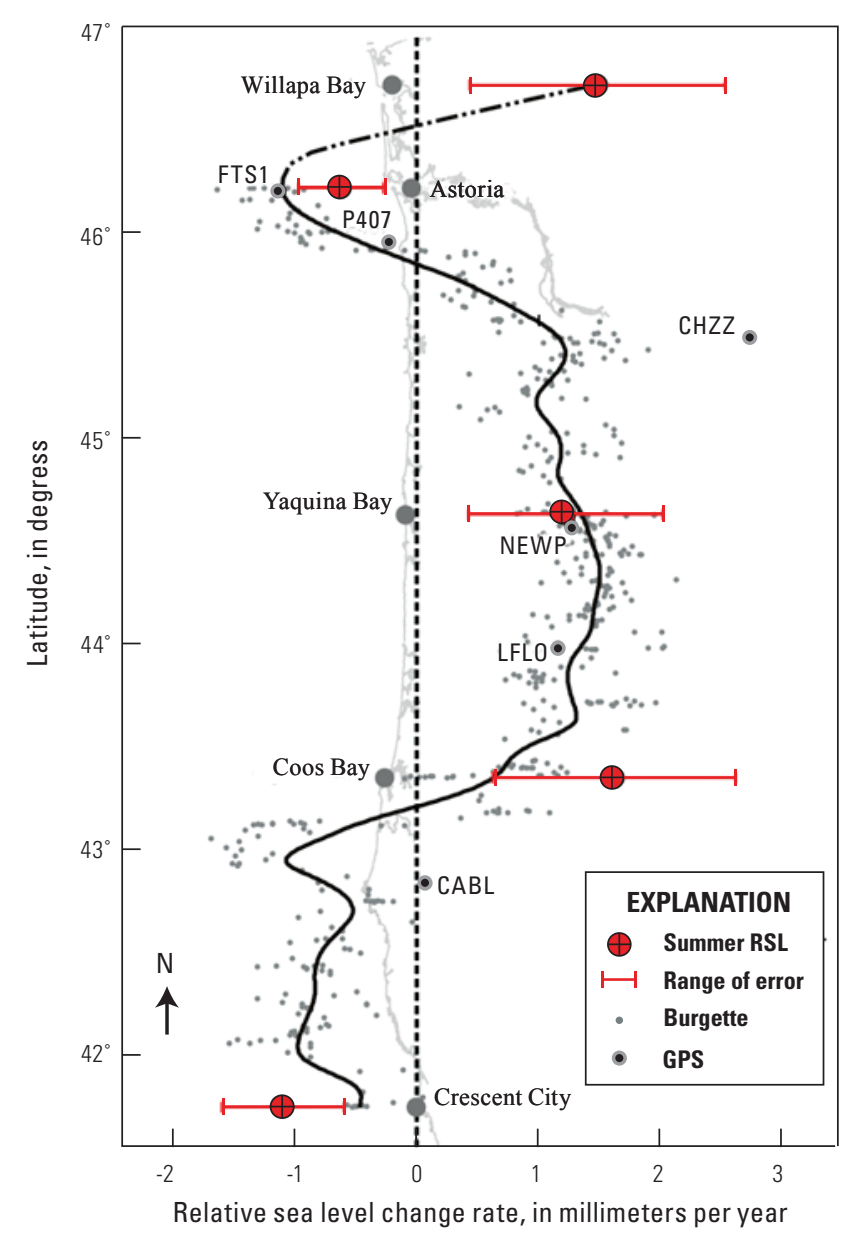

Figure 10. Alongshore varying rates of relative sea level rise (black line) as determined by three methods from Komar and others (2011). (1) Tide gage records with trends based on averages of the summer-only monthly mean water levels (red circles with plusses; error bars represent the 95 percent confidence interval on the trends). (2) The Burgette and others (2009) benchmark survey estimates of uplift rates modified by the regional mean sea-level rise rate of 2.3 millimeters per year; small gray dots (3) The uplift rates estimated from Global Positioning System (GPS) sites along the coast subtracted from the regional mean sea level rise rate (small filled black circles). CHZZ, Tillamook; CABL, Cape Blanco; FTS1, Fort Stevens 1; LFLO, Florence Coop; NEWP, Newport; RSL, relative sea level.

\section{Littoral Cells, Sediment Sources, and Transport}

After the last glacial maximum, as glaciers began to melt and the sea began to rise, the shoreline migrated landward across the continental shelf. The beaches at this time were probably relatively continuous and, because there were no headlands on the shores, waves transported sediments along the beaches both northward and southward from the Klamath Mountains, the Coast Range, and the Columbia River (fig. 2). However, mineral analyses indicate that, for the most part, the net transport of material was toward the north. About 6,000 years ago, the headlands began to segment much of the PNW coast (Clemens and Komar, 1988). With the PNW coast having alternating stretches of resistant rocky shores and stretches backed by more easily eroded sedimentary formations, today's coast consists of a series of littoral cells (fig. 11). Along the Oregon coast, each stretch of shore within a littoral cell is in effect a pocket beach, with its sand generally unable to pass around the headlands that extend well offshore into deep water (Komar, 1997). Therefore, although sediment derived from both the Klamath Mountains and the Columbia River is still present in Oregon littoral cells, it reached those cells thousands of years ago and does not represent a modernday source of beach sediment. The littoral cells range widely in their alongshore lengths, from a few to tens of kilometers, governed by the distances between the bounding headlands. The longest is the Coos littoral cell (fig. 11), which contains the massive Oregon Dunes, the largest field of coastal dunes in the United States.

In contrast to the isolated pocket-beach character of Oregon's littoral cells, the southwestern Washington coast is dominated by the large CRLC (fig. 3), which includes the Long Beach Peninsula where there is a net transport of beach sand toward the north. Point Grenville, Wash., is the terminating northern boundary of the CRLC (Gelfenbaum and Kaminsky, 2010). Further to the north, beyond the CRLC, the Olympic Peninsula part of Washington coast is predominantly rocky, containing only relatively small pocket beaches of sand and gravel. This coast is significantly less developed, including coastline along Native American settlements and the coastal part of Olympic National Park.

The 1982-3 and 1997-8 El Niño events produced major redistributions of beach sand volumes within Oregon's pocket beach littoral cells, leading to occurrences of hotspot erosion. This redistribution of sand and the resulting areas of erosion follow a consistent pattern in the littoral cells, illustrated schematically in figure 12, where the effects of an El Niño event on the sediment movement and erosion within a littoral cell is contrasted with its relative stability during typical years (Komar, 1986, 1998). During typical years there is a quasiequilibrium, with the winter storm waves predominantly arriving from the southwest, transporting sand alongshore to the north. The calm weather waves from the northwest return the sand to the south, and in the long term, there is on average a net-zero longshore sediment transport. In contrast, during a year when a major El Niño event takes place, the pattern of change involves erosion north of headlands and also north of inlets due to their migration; in addition, there can be erosion where inlets are controlled by jetties because these structures act much like mini headlands (fig. 12). At the same time, beach sand accumulates south of the headlands. These changes are produced by an unusual degree of northward transport and displacement of the beach sand during El Niño winters, far greater than during typical years (Komar, 1986, 1998).

This interpretation based on a northward displacement of sand within the PNW littoral cells is supported by analyses 


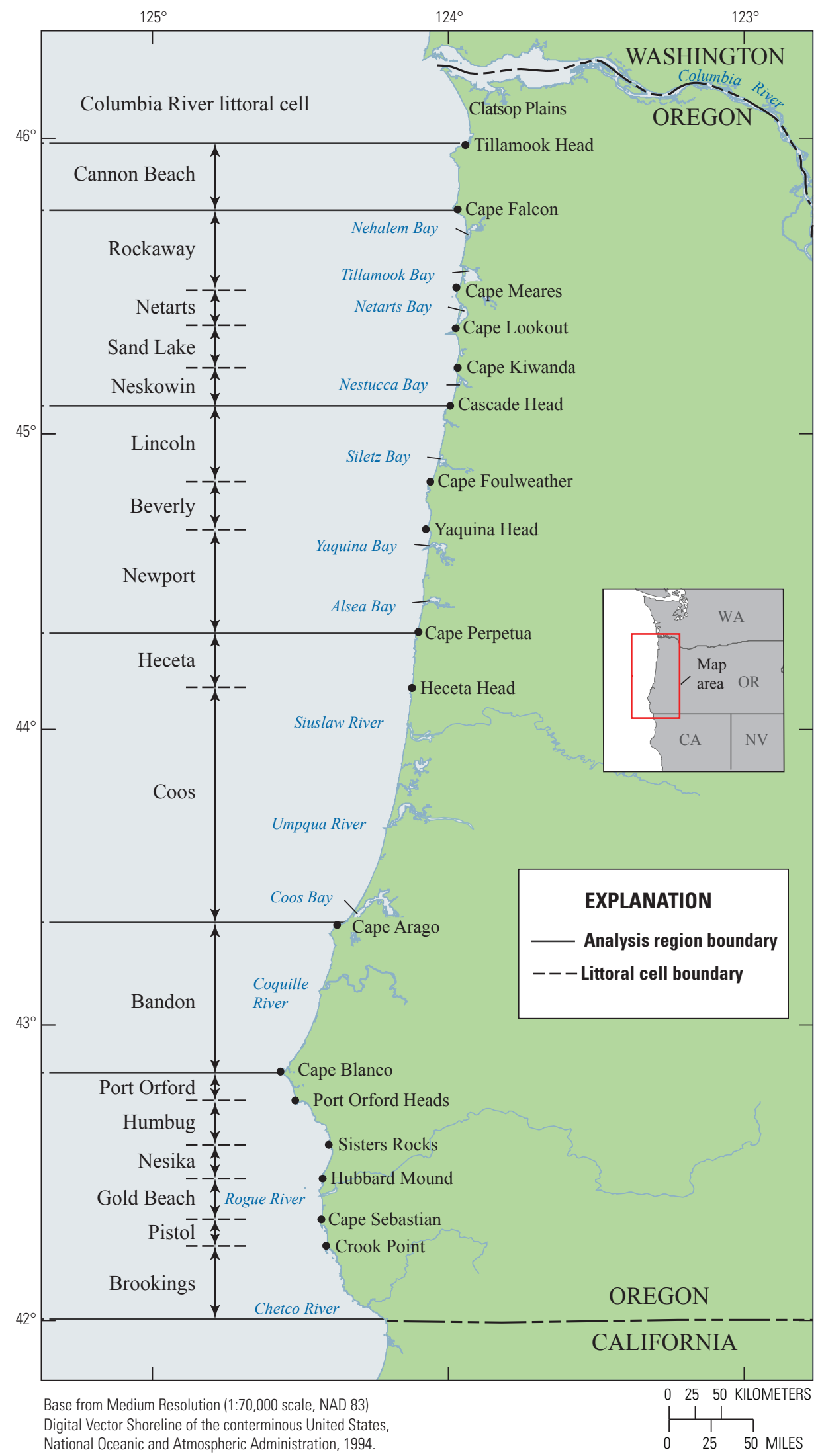

Figure 11. The 18 littoral cells that make up the coast of Oregon, including the Clatsop Plains subcell of the Columbia River littoral cell, which extends into Washington (fig. 3). 


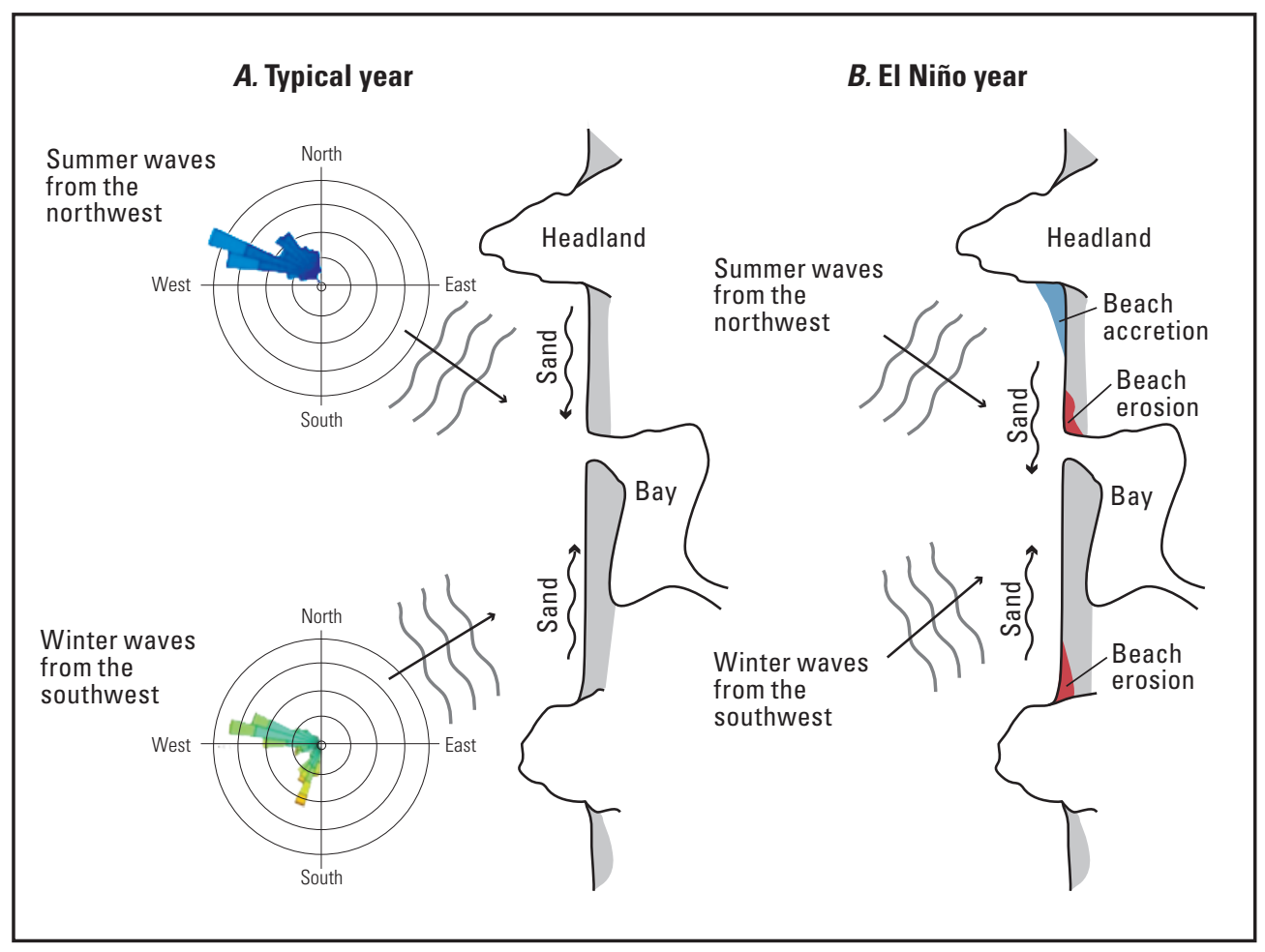

Figure 12. Schematic diagram of sand movement along the beaches within Oregon's littoral cells between rocky headlands due to the seasonal changes in wave directions, comparing the equilibrium balance during $A$, typical years with $B$, major El Niño events when the waves transport greater volumes of sand (gray shading) to the north (blue shading), resulting in zones of hotspot erosion (red shading).

of the El Niño storms. Seymour (1996) documented that storm centers shifted to the south compared with typical years, such that the storm tracks mainly crossed the coast of central California rather than approaching the shores of the PNW. As a result, when these storm waves did reach the Oregon and Washington coast from a more southwesterly quadrant, a larger than average northward transport of the beach sand within the littoral cells was created, resulting in hotspot erosion effects along the shores of central to northern California and particularly along the PNW coast. During the strong El Niño of 1982-3, large wave heights and acute southerly wave angles forced an increased magnitude of offshore and northerly sand transport in Oregon, causing severe beach erosion and changes in shoreline orientation that persisted for several years (Komar, 1986; Peterson and others, 1990). The magnitude of beach change during the 1982-3 El Niño was not documented by detailed surveys. However, the higher than typical annual net northward sediment transport and subcell shoreline reorientation associated with the 1997-8 El Niño was documented by Kaminsky and others (1998) and Ruggiero and others (2005) in the CRLC and by Revell and others (2002) in Oregon.

\section{Coastal Landforms of the Pacific Northwest Coast}

The Oregon and Washington coastline encompasses a wide range of coastal landforms, a product of complex geology and dynamic coastal processes. Coastal landforms include sandy and cobble beaches backed by coastal dunes, coastal bluffs, or steep cliffs. The PNW coastline also includes uplifted terraces, barrier spits, and estuaries and lagoons (fig. 13; table 6).

\section{Dune-Backed Beaches}

Coastal dunes back about 45 percent of the Oregon and Washington outer coasts with some of the sand sheets in the region (Oregon Dunes) being the largest complex of coastal dunes in North America (Cooper, 1958). Historically, dunes in the PNW region were managed to maximize coastal protection through the planting of European beach grass, Ammophila arenaria (A. arenaria). The switch in dominance from the native species Elymus mollis to an exotic dune species 
$\boldsymbol{A}$

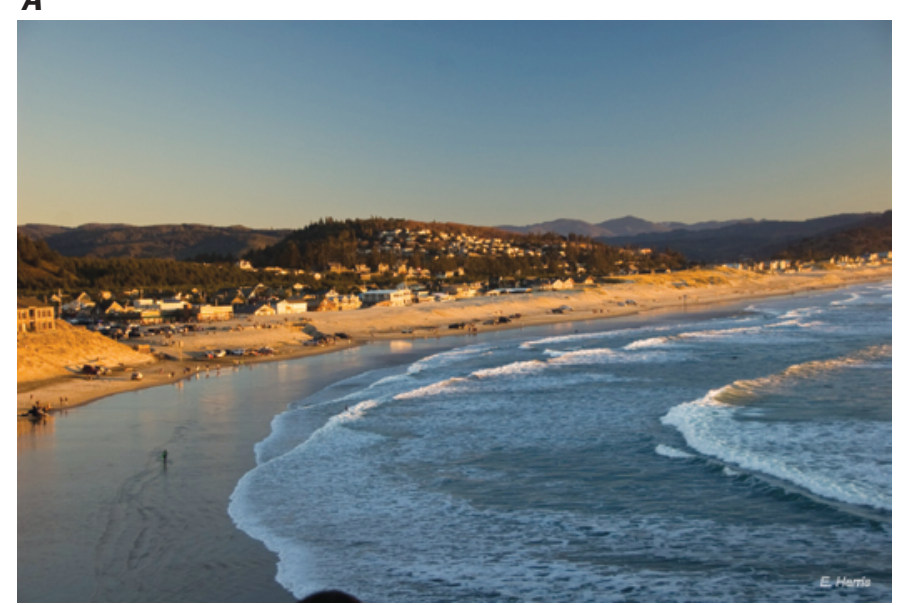

B

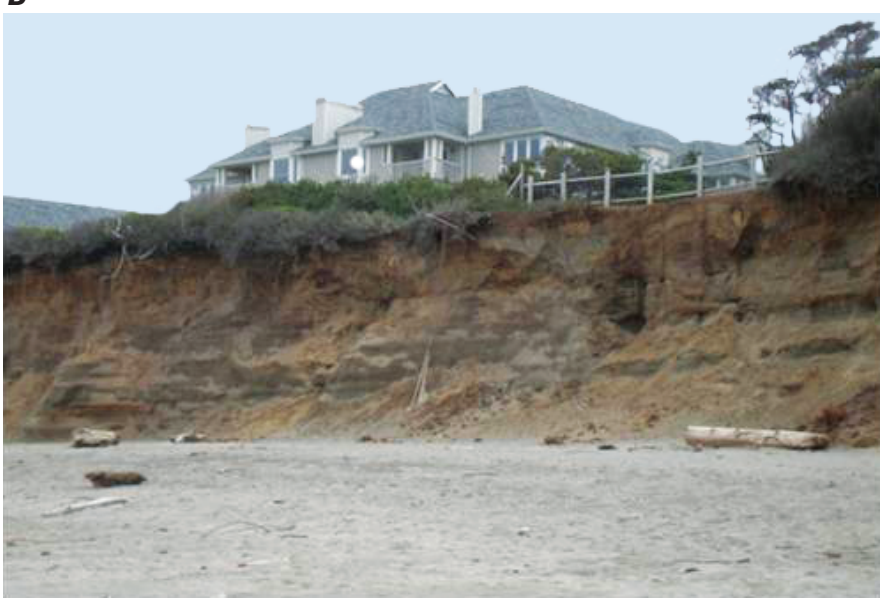

\section{C}

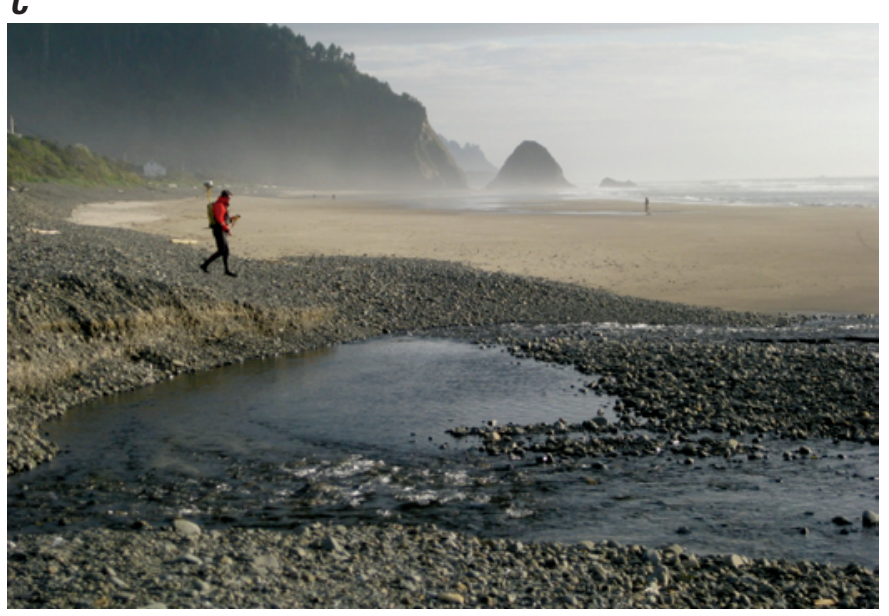

\section{D}

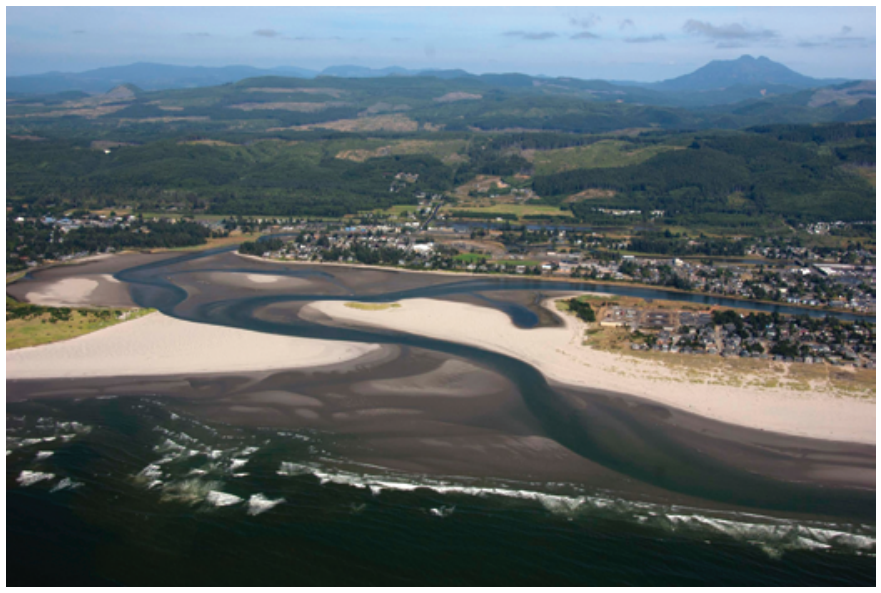

$E$

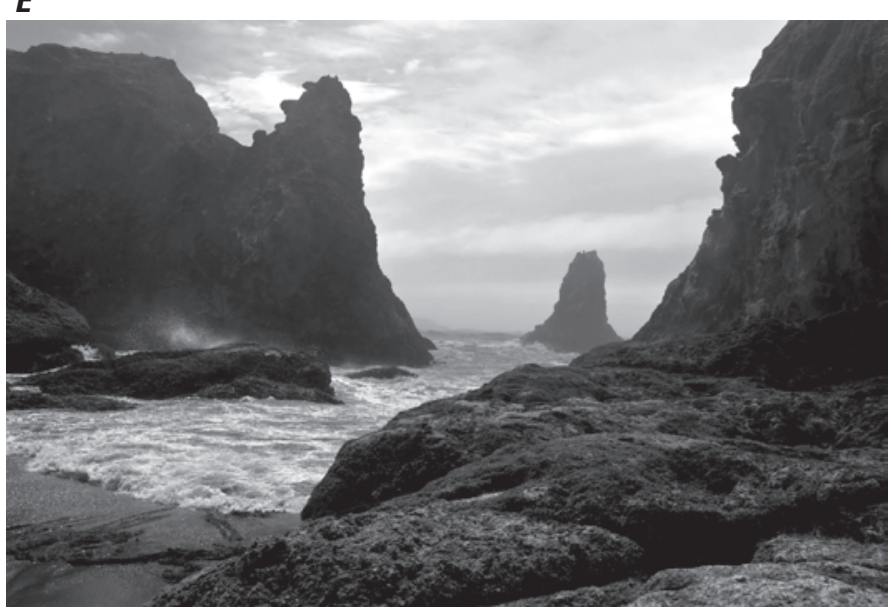

$\boldsymbol{F}$

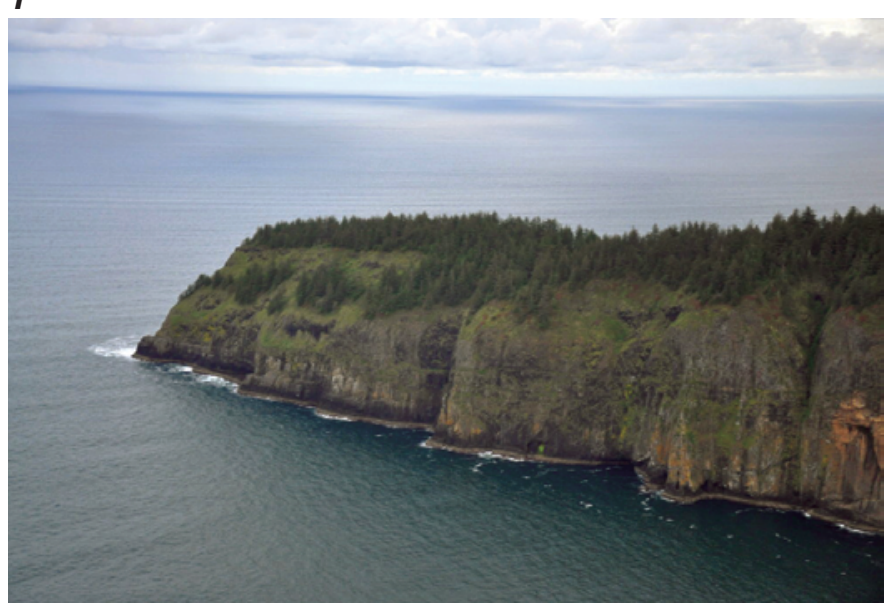

Figure 13. Coastal landforms along the Pacific Northwest coast. $A$, The dunes of Pacific City (photograph by Erica Harris, Oregon Department of Geology and Mineral Industries); $B$, eroding Pleistocene bluffs in Gleneden Beach (photograph by Jonathan Allan, Oregon Department of Geology and Mineral Industries); $C$, cobble beach at Arch Cape (photograph by Laura Stimely, Oregon Department of Geology and Mineral Industries); $D$, the barrier spit complex fronting the Sand Lake Estuary (photograph by Erica Harris, Oregon Department of Geology and Mineral Industries); $E$, sea stacks at Bandon (photograph by Erica Harris, Oregon Department of Geology and Mineral Industries); and F, plunging cliffs of Cape Lookout [photograph copyright Oregon ShoreZone imaging project photograph 3349 (http://www.coastalatlas.net/shorezone/photodisplay.php?p=3349)]. 
Table 6. Regional geomorphic coastal features of Oregon and Washington.

[Data are from Hapke and others (in press). CRLC, Columbia River littoral cell]

\begin{tabular}{|c|c|c|c|c|c|c|c|c|}
\hline \multirow{2}{*}{ Coastal feature } & \multicolumn{8}{|c|}{ Region name and number } \\
\hline & \multicolumn{6}{|c|}{ Oregon } & $\begin{array}{c}\text { Oregon and } \\
\text { Washington }\end{array}$ & $\begin{array}{l}\text { Washington, } \\
\text { Olympic } \\
\text { Peninsula } \\
8\end{array}$ \\
\hline Rocky shorelines and shore platforms & $\mathrm{x}$ & $\mathrm{x}$ & & $\mathrm{x}$ & & $\mathrm{x}$ & & $\mathrm{x}$ \\
\hline Wide and narrow sandy beaches backed by cliffs & $\mathrm{x}$ & $\mathrm{x}$ & & $\mathrm{x}$ & $\mathrm{x}$ & $\mathrm{x}$ & $\mathrm{x}$ & $\mathrm{x}$ \\
\hline Gravel and cobble beaches backed by cliffs & $\mathrm{x}$ & & & & $\mathrm{x}$ & $\mathrm{x}$ & & $\mathrm{x}$ \\
\hline Plunging cliffs & $\mathrm{x}$ & $\mathrm{x}$ & $\mathrm{x}$ & $\mathrm{x}$ & $\mathrm{x}$ & $\mathrm{x}$ & $\mathrm{x}$ & $\mathrm{x}$ \\
\hline Barrier spits & & $\mathrm{x}$ & $\mathrm{x}$ & $\mathrm{x}$ & $\mathrm{x}$ & $\mathrm{x}$ & $\mathrm{x}$ & $\mathrm{x}$ \\
\hline
\end{tabular}

resulted in a complete state change in coastal dune systems (Seabloom and Wiedemann, 1994). Before the invasion of the exotic species, the native dune plants formed small hillocks or short parallel ridges depending on sand supply. In contrast, $A$. arenaria creates stable foredunes, with dune ridges reaching as much as 15 to $20 \mathrm{~m}$ tall, which intercept sand and decrease sand supply to the backshore. A second invasive species, Ammophila breviligulata (American beach grass), was introduced to the PNW in the middle of the 20th century and also influences coastal dune geomorphology (Hacker and others, 2012; Zarnetske and others, 2012). Today, these foredune ridges protect coastal communities and infrastructure from wave overtopping and inundation (Sallenger, 2000), but also have implications for native dune species and habitat conservation (Seabloom and Wiedemann, 1994; Wiedemann and Pickart, 2004; Zarnetske and others, 2010; Hacker and others, 2012). The dune fields (fig. 13A) of Pacific City, Oreg., are an example of foredunes dominated by exotic grasses.

\section{Cliff- and Bluff-Backed Beaches}

Cliff-backed shorelines make up the bulk of the Oregon coast (58 percent) and to a lesser extent the open coast of Washington (22 percent). The majority of cliffs on the central to northern Oregon coast may be classified as having low to moderately high relief $(10-20 \mathrm{~m})$, formed from erosion into marine terraces such as at Gleneden Beach, Oreg. (fig. 13B). The mean cliff slope (Hapke and others, in press) is about 43 degrees $\left({ }^{\circ}\right)$. On parts of the northern Oregon coast, such as at Cannon Beach, Oreg. (fig. 2A), coastal cliffs are protected by dissipative sand beaches that are backed by a veneer of gravel (shingle to cobble). These cliffs are mostly stable, evident by highly vegetated seaward slopes, or have experienced erosion in the past, evident by the presence of coastal engineering structures, and are now highly vegetated. On the southern Oregon coast, the cliff-backed shorelines are characterized by moderately high relief (heights 20-30 m; Hapke and others, in press). The slope of the cliffs varies from about $34^{\circ}$ to $45^{\circ}$ in both Quaternary marine terrace sediment and sheared Mesozoic sedimentary and metamorphic rocks.

\section{Gravel and Boulder Beaches}

Late Holocene gravels (pebbles to cobbles) and boulders abut many of the coastal headlands, where they form prominent, steep, natural barriers to wave erosion. For example, much of Seaside, Oreg., (fig. 2) is built on a $3.7-\mathrm{km}$-long spit made of basalt cobbles that originated as rocky debris produced by landslides on Tillamook Head. Gravels are also prevalent along much of the Clatsop County shoreline and form a generally thin veneer at the back of most beaches in southern Cannon Beach, Hug Point, and Arcadia Beach, Oreg. With progress south, the gravels increase in size and volume and form a substantial gravel beach at Arch Cape, Oreg. (fig. 13C), culminating in an impressive cobble berm at Falcon Cove.

\section{Barrier Spits, Estuaries, and Lagoons}

The coastal rivers of the PNW cut valleys during the low sea level stands that accompanied glacier advances. When the glaciers melted and sea level rose, these valleys were drowned and formed estuaries, which today are important fisheries and harbors. There are 43 estuaries and tidal creeks along the Oregon coast (11 of which have entrances fixed in place by jetties), but most of these estuaries are relatively small (less 
than 10 square kilometers $\left(\mathrm{km}^{2}\right)$; Lee and Brown, 2009). The geomorphology of PNW estuaries is diverse, including tidaldominated drowned river mouths, river-dominated drowned river mouths, bar-built coastal lagoons, and numerous tidal creeks. Most of the major coastal rivers in the PNW are separated from the Pacific Ocean by estuaries, which prevent them from delivering significant amounts of sand to modern beaches. The major exception to this is the Columbia River which at least in the early historical period transported a significant amount of sediment to the coast. At present, as a result of damming, the amount of sediment leaving the lower Columbia River Estuary and making its way onto beaches is unknown (Gelfenbaum and Kaminsky, 2010). Many PNW estuaries are fronted by barrier spits, for example the barrier spit complex fronting Sand Lake Estuary, Oreg. (fig. 13D).

\section{Rocky Shorelines and Shore Platforms}

Along several stretches of the Pacific Northwest coastline, such as the Olympic Peninsula and the Bandon area (fig. 13E), differential erosion of the Tertiary sediments and volcanic rocks has resulted in the formation of dramatic stacks, arches, sea caves and high cliffs. These and other areas in the region are considered to be some of the great scenic coasts of the world.

\section{Plunging Cliffs}

High plunging cliffs are associated with the major headlands of the PNW (fig. 13F) and reach heights of nearly $120 \mathrm{~m}$, with the steepest slopes approaching about $85^{\circ}$ (Hapke and others, in press).

\section{Historical Shoreline Change Analysis}

The results of the PNW shoreline change analysis are presented in this section. For the purposes of this assessment, the PNW coast is subdivided into eight regions (fig. 1), which are based broadly on coastal geomorphology and used to graphically present the long- and short-term shoreline change rates. However, the littoral cell is the appropriate scale for considering sediment dynamics and budgets of net sediment gains and losses, so both long- and short-term rates of shoreline change are averaged for each littoral cell (figs. 3 and 11; tables 7 and 8 ). Tables 7 and 8 provide the regionally averaged shoreline change rates and the associated average rate uncertainty computed using equations 7 and 9 (see Regionally Averaged Rate Uncertainty section). Uncertainty values calculated using equation 9 , as determined using a reduced effective sample size, are generally much smaller than the arithmetic mean CIs.

In the discussions below, shoreline change rates are referenced from tables 7 and 8 and presented as the regionally averaged net rate for the long- (1800s through 2002) and short-term (1960s or 80s through 2002) analyses. For the rates reported in this report, erosional trends are presented as negative values, and progradational trends are presented as positive values. The regionally averaged net change rates are the averages of both negative (erosional) and positive (progradational or accretional) rates. Additionally, the percentage of the measured coastline that is eroding as well as the percentage that is eroding at rates faster than -1 meter per year $(\mathrm{m} / \mathrm{yr})$ and $-3 \mathrm{~m} / \mathrm{yr}$ are presented. Tables 7 and 8 also present the range of shoreline change rates within each littoral cell. Typically, the littoral-cell-wide average shoreline change rates are close to zero; however, within a particular littoral cell there is significant variability that includes stretches of both erosion and accretion.

A statistical t-test was performed to determine whether the long- and short-term rates were significantly different from one another at the 90-percent CI. The t-test results indicate that the difference between long- and short-term rates is statistically significant in all regions except for the Humbug littoral cell in the southern Oregon region and the North Beach subcell of the CRLC in Washington. In Washington, the Long Beach subcell of the CRLC is more progradational in the short-term. The Grayland Plains subcell of the CRLC and the Olympic Peninsula littoral cell is net erosional in the long term but net accretional in the short term. In Oregon, however, 13 of the 18 littoral cells are either less accretional, changed from accretional to erosional, or more erosional when comparing the long- and short-term rate calculations.

The average net rate of long-term shoreline change was $0.4 \mathrm{~m} / \mathrm{yr}$ for Oregon and $2.2 \mathrm{~m} / \mathrm{yr}$ for Washington, both being accretional trends (table 7). These rates are based on shoreline change rates averaged from 8,823 individual transects (table 7), 36 percent of which was eroding. The analysis showed (table 7) that only three littoral cells in Oregon and two in Washington experienced statistically significant longterm negative net shoreline change: Humbug $(-0.4 \mathrm{~m} / \mathrm{yr})$, Heceta $(-0.4 \mathrm{~m} / \mathrm{yr})$, and Netarts $(-0.5 \mathrm{~m} / \mathrm{yr})$ in Oregon and Grayland Plains $(-1.9 \mathrm{~m} / \mathrm{yr})$ and Olympic Peninsula $(-0.4 \mathrm{~m} / \mathrm{yr})$ in Washington. The highest negative (erosional) regionally averaged net rate was measured in the Grayland Plains subcell. Whereas Washington was generally more accretional than Oregon in the long term, a greater percentage of the Washington coast was eroding at higher rates in the long term: 7 percent of the Washington coast was eroding at rates greater than $-1 \mathrm{~m} / \mathrm{yr}$ compared with 4 percent of the Oregon coast (table 7). In Washington, only 4 percent of the coast was found to be eroding at rates greater than $-3 \mathrm{~m} / \mathrm{yr}$ in the long term, whereas in Oregon the percentage of coast eroding at rates greater than $-3 \mathrm{~m} / \mathrm{yr}$ was negligible.

The average net rate of short-term change for the PNW was $0.9 \mathrm{~m} / \mathrm{yr}$ based on 9,087 transects , 44 percent of which was eroding (table 8). Statistically significant negative (erosional) net short-term shoreline change was measured in 10 of the 18 littoral cells in Oregon (as opposed to 3 in the long term). The percentage of coast eroding in the short term was higher in Oregon (54 percent) than in Washington 
Table 7. Long-term shoreline change rate uncertainties, rates, and range of rates for the Pacific Northwest coast.

[Red values indicate that the rates are statistically significant. Blue values indicate statewide maximums; CRLC, Columbia River littoral cell; m, meters; $\mathrm{n}$, sample size; $\mathrm{m} / \mathrm{yr}$, meters per year; $\mathrm{n}$, sample size; <, less than; --, not applicable]

\begin{tabular}{|c|c|c|c|c|c|c|c|c|c|}
\hline \multirow[b]{2}{*}{ Littoral cell } & \multirow{2}{*}{$\begin{array}{c}\text { Number } \\
\text { of } \\
\text { transects }\end{array}$} & \multirow{2}{*}{$\begin{array}{c}\text { Average } \\
\text { uncertainty } \\
\text { (m) }\end{array}$} & \multirow[b]{2}{*}{$\begin{array}{c}\text { Independent } \\
\mathbf{n}\end{array}$} & \multirow{2}{*}{$\begin{array}{l}\text { Average of rates (m/yr) } \\
\text { with uncertainty } \\
\text { reduced for } \\
\text { independent } n \\
\text { (m) }\end{array}$} & \multicolumn{3}{|c|}{ Percent eroding } & \multicolumn{2}{|c|}{$\begin{array}{c}\text { Maximum rate } \\
(\mathrm{m} / \mathrm{yr})\end{array}$} \\
\hline & & & & & Total & $\begin{array}{l}\text { More } \\
\text { than } \\
-1 \mathrm{~m} / \mathrm{yr}\end{array}$ & $\begin{array}{l}\text { More } \\
\text { than } \\
-3 \mathrm{~m} / \mathrm{yr}\end{array}$ & Erosion & Accretion \\
\hline \multicolumn{10}{|c|}{ Oregon } \\
\hline Brookings & 107 & 0.9 & 29 & $0.4 \pm 0.2$ & 28 & 0 & 0 & -0.5 & 2.0 \\
\hline Pistol & 88 & 1.9 & 14 & $0.2 \pm 0.5$ & 26 & 0 & 0 & -0.3 & 1.4 \\
\hline Gold Beach & 246 & 1.9 & 7 & $0.4 \pm 0.7$ & 40 & 0 & 0 & -0.8 & 3.4 \\
\hline Nesika & 171 & 0.8 & 41 & $0.0 \pm 0.1$ & 36 & 0 & 0 & -1.0 & 0.6 \\
\hline Humbug & 95 & 1.5 & 16 & $-0.4 \pm 0.38$ & 94 & 2 & 0 & -1.0 & 0.2 \\
\hline Port Orford & 195 & 0.4 & 24 & $0.0 \pm 0.1$ & 64 & 0 & 0 & -0.6 & 1.0 \\
\hline Bandon & 857 & 1.1 & 27 & $0.0 \pm 0.2$ & 52 & 5 & 0 & -1.3 & 2.2 \\
\hline Coos & 1,641 & 1 & 13 & $0.5 \pm 0.3$ & 26 & 0 & 0 & -0.9 & 6.5 \\
\hline Heceta & 115 & 0.9 & 9 & $-0.4 \pm 0.3$ & 97 & 3 & 0 & -1.1 & 0.3 \\
\hline Newport & 622 & 1.2 & 27 & $0.5 \pm 0.2$ & 30 & 0 & 0 & -1.1 & 8 \\
\hline Beverly & 146 & 1.3 & 7 & $-0.2 \pm 0.5$ & 68 & 0 & 0 & -0.7 & 0.7 \\
\hline Lincoln & 414 & 1.1 & 4 & $0.1 \pm 0.5$ & 46 & 1 & 0 & -1.2 & 2.8 \\
\hline Neskowin & 260 & 0.9 & 6 & $-0.3 \pm 0.5$ & 88 & 0 & 0 & -1.0 & 0.9 \\
\hline Sand Lake & 223 & 1.7 & 24 & $-0.1 \pm 0.4$ & 57 & 1 & 0 & -1.6 & 2.3 \\
\hline Netarts & 220 & 1.1 & 13 & $-0.5 \pm 0.3$ & 80 & 10 & 0 & -1.1 & 1.3 \\
\hline Rockaway & 499 & 1.6 & 8 & $0.3 \pm 0.3$ & 40 & 22 & 0 & -2.8 & 5.1 \\
\hline Cannon Beach & 214 & 1.7 & 9 & $0.2 \pm 0.6$ & 35 & 0 & 0 & -0.5 & 3.4 \\
\hline CRLC, Clatsop Plains & 554 & 2.5 & 5 & $3.1 \pm 1.1$ & 10 & 10 & 2 & -3.6 & 15.5 \\
\hline \multicolumn{10}{|c|}{ Washington } \\
\hline \multicolumn{10}{|l|}{ CRLC: } \\
\hline Long Beach & 810 & 1.4 & 9 & $2.6 \pm 0.4$ & 17 & 8 & 3 & -12.1 & 10.3 \\
\hline Grayland Plains & 428 & 2.1 & 4 & $-1.9 \pm 1.1$ & 30 & 17 & 16 & -28.6 & 6.6 \\
\hline North Beach & 793 & 1.2 & 8 & $4.4 \pm 0.4$ & 1 & 0 & 0 & -0.6 & 21.8 \\
\hline Olympic Peninsula & 125 & 0.4 & 14 & $-0.4 \pm 0.1$ & 87 & 0 & 0 & -0.9 & 0.4 \\
\hline \multicolumn{10}{|c|}{ Total } \\
\hline Oregon & 6,667 & 1.3 & 284 & $0.4 \pm 0.08$ & 41 & 4 & $<1$ & -- & -- \\
\hline Washington & 2,156 & 1.4 & 35 & $2.2 \pm 0.24$ & 18 & 7 & 4 & -- & -- \\
\hline Pacific Northwest & 8,823 & 1.3 & 319 & $0.9 \pm 0.07$ & 36 & 4 & 1 & -- & -- \\
\hline
\end{tabular}

(9 percent). The percentages of coastline eroding at shortterm rates greater than $-1 \mathrm{~m} / \mathrm{yr}$ was 18 percent in Oregon and 7 percent in Washington. However, a higher percentage of the Washington coast (6 percent versus less than 1 percent in Oregon) is eroding at faster rates in the short-term (more than $-3 \mathrm{~m} / \mathrm{yr})$.

\section{Oregon}

The shoreline change analysis of Oregon covers a shoreline of about $560 \mathrm{~km}$ long (fig. 1). For the graphical presentation of the shoreline change analysis, Oregon was divided into six regions - southern Oregon, Bandon, Coos, Lincoln County, Tillamook County, Cannon Beach, and the Clatsop Plains subcell of the CRLC (fig. 3).

\section{Southern Oregon-California Border to Cape Blanco}

The southern Oregon analysis region (fig. 14) extends about $100 \mathrm{~km}$ between the California border and Cape Blanco, Oreg., and contains six littoral cells (fig. 11)-Brookings (about $34 \mathrm{~km}$ ), Pistol (about $8 \mathrm{~km}$ ), Gold Beach (about $15 \mathrm{~km}$ ), Nesika (about $9 \mathrm{~km}$ ), Humbug (about $20 \mathrm{~km}$ ), and Port Orford (about $11 \mathrm{~km}$ ). On the southern Oregon coast, the coastline is chiefly hard rock bluffs interspersed with small pocket beaches composed of sand or sand and gravel with clasts up to boulder size. The cliff-backed shorelines are characterized by moderately high relief (about 20-30 m), with the highest elevations reflecting the locations of prominent headlands. 
Table 8. Short-term shoreline change rate uncertainties, rates, and range of rates for the Pacific Northwest coast.

[Red values indicate that the rates are statistically significant. Blue values indicate statewide maximums; CRLC, Columbia River littoral cell; m, meters; n, sample size; $\mathrm{m} / \mathrm{yr}$, meters per year; $<$, less than; --, not applicable]

\begin{tabular}{|c|c|c|c|c|c|c|c|c|c|}
\hline \multirow[b]{2}{*}{ Littoral cell } & \multirow{2}{*}{$\begin{array}{c}\text { Number } \\
\text { of } \\
\text { transects }\end{array}$} & \multirow{2}{*}{$\begin{array}{c}\text { Average } \\
\text { uncertainty } \\
\text { (m) }\end{array}$} & \multirow[b]{2}{*}{$\begin{array}{c}\text { Independent } \\
\mathbf{n}\end{array}$} & \multirow{2}{*}{$\begin{array}{l}\text { Average of rates } \\
\text { (m/yr) } \\
\text { with uncertainty } \\
\text { reduced for } \\
\text { independent } n \\
(\mathrm{~m})\end{array}$} & \multicolumn{3}{|c|}{ Percent eroding } & \multicolumn{2}{|c|}{$\begin{array}{c}\text { Maximum rate } \\
(\mathrm{m} / \mathrm{yr})\end{array}$} \\
\hline & & & & & Total & $\begin{array}{c}\text { More } \\
\text { than } \\
-1 \mathrm{~m} / \mathrm{yr}\end{array}$ & $\begin{array}{c}\text { More } \\
\text { than } \\
-3 \mathrm{~m} / \mathrm{yr}\end{array}$ & Erosion & Accretion \\
\hline \multicolumn{10}{|c|}{ Oregon } \\
\hline Brookings & 179 & 0.5 & 37 & $-0.05 \pm 0.1$ & 58 & 0 & 0 & -1 & 2 \\
\hline Pistol & 133 & 0.6 & 32 & $0.5 \pm 0.1$ & 14 & 0 & 0 & -0.6 & 2.2 \\
\hline Gold Beach & 270 & 0.6 & 40 & $0.6 \pm 0.1$ & 22 & 10 & 0 & -1.9 & 2.7 \\
\hline Nesika & 205 & 0.6 & 13 & $-0.4 \pm 0.2$ & 75 & 13 & 0 & -2 & 2 \\
\hline Humbug & 128 & 0.6 & 36 & $-0.4 \pm 0.1$ & 79 & 11 & 0 & -1.3 & 1.7 \\
\hline Port Orford & 195 & 0.6 & 26 & $-0.3 \pm 0.1$ & 65 & 24 & 0 & -2.4 & 2.5 \\
\hline Bandon & 920 & 0.5 & 40 & $0.2 \pm 0.1$ & 39 & 6 & 0 & -2 & 3.4 \\
\hline Coos & 1,652 & 0.5 & 88 & $0.03 \pm 0.1$ & 54 & 8 & 1 & -3.9 & 5.6 \\
\hline Heceta & 151 & 0.6 & 36 & $-0.1 \pm 0.1$ & 66 & 1 & 0 & -1.1 & 1.3 \\
\hline Newport & 686 & 0.6 & 105 & $-0.5 \pm 0.1$ & 73 & 33 & 0 & -2.6 & 6.3 \\
\hline Beverly & 146 & 0.5 & 14 & $-1.1 \pm 0.1$ & 100 & 51 & 0 & -2.4 & -- \\
\hline Lincoln & 423 & 0.5 & 38 & $-0.3 \pm 0.1$ & 72 & 15 & 0 & -2 & 2.9 \\
\hline Neskowin & 261 & 0.6 & 36 & $-1.1 \pm 0.1$ & 86 & 58 & 0 & -3 & 2.5 \\
\hline Sand Lake & 232 & 0.6 & 33 & $-0.5 \pm 0.1$ & 63 & 38 & 0 & -2.2 & 1.8 \\
\hline Netarts & 226 & 0.5 & 19 & $-1.0 \pm 0.1$ & 86 & 69 & 0 & -2.2 & 1.7 \\
\hline Rockaway & 500 & 0.5 & 34 & $0.6 \pm 0.1$ & 47 & 25 & 3 & -4.4 & 26.5 \\
\hline Cannon Beach & 245 & 0.6 & 41 & $-0.5 \pm 0.1$ & 75 & 25 & 0 & -2.4 & 2.3 \\
\hline CRLC, Clatsop Plains & 561 & 0.5 & 20 & $1.9 \pm 0.1$ & 2 & 0 & 0 & -1.4 & 9 \\
\hline \multicolumn{10}{|c|}{ Washington } \\
\hline \multicolumn{10}{|l|}{ CRLC: } \\
\hline Long Beach & 741 & 1.5 & 19 & $4.7 \pm 0.3$ & 3 & 3 & 2 & -18.7 & 23.2 \\
\hline Grayland Plains & 395 & 1.4 & 5 & $1.7 \pm 0.6$ & 30 & 29 & 23 & -56.5 & 43.1 \\
\hline North Beach & 792 & 1.7 & 13 & $4.2 \pm 0.5$ & 3 & 0 & 0 & -1.3 & 13.1 \\
\hline \multicolumn{10}{|l|}{ Olympic Peninsula: } \\
\hline & 46 & 0.9 & 8 & $0.3 \pm 0.3$ & 33 & 0 & 0 & -0.3 & 1.4 \\
\hline $1920 s-2002$ & 1,273 & 0.13 & 27 & $-0.02 \pm 0.02$ & 46 & 1.3 & 0 & -- & -- \\
\hline \multicolumn{10}{|c|}{ Total } \\
\hline Oregon & 7,113 & 0.5 & 688 & $0.03 \pm 0.02$ & 54 & 18 & $<1$ & -- & -- \\
\hline Washington & 1,974 & 1.6 & 45 & $3.8 \pm 0.2$ & 9 & 7 & 6 & -- & -- \\
\hline Pacific Northwest & 9,087 & 0.77 & 733 & $0.9 \pm 0.03$ & 44 & 15 & 2 & -- & -- \\
\hline
\end{tabular}

The Brookings littoral cell extends from the California border to Saddle Rock, Oreg. Brookings Harbor is located immediately upchannel from a pair of jetties on the Chetco River and consists of two basins, one for commercial fishing vessels, the other (sports basin) for smaller private boats (Komar and others, 1996). Substantial damage to the docks and boats occurred during the tsunami that resulted from the magnitude 9 earthquake in Tohuku, Japan, on March 11, 2011 (Allan and others, 2012). Much of the commercial part of the harbor was destroyed, as was about a third of the sports basin; the total damage has been estimated to be about $\$ 10$ million. In the long term, the net shoreline change rate, averaged over 107 transects, was $0.4 \mathrm{~m} / \mathrm{yr}$ in the Brookings cell, ranging from -0.5 to $2.0 \mathrm{~m} / \mathrm{yr}$. Twenty-eight percent of transects in the
Brookings littoral cell was experiencing erosion in the longterm, but none of the coast was experiencing erosion rates greater than $-1 \mathrm{~m} / \mathrm{yr}$ (table 7 ). In the short term, the shoreline change rate in the Brookings cell was statistically insignificant as averaged over 179 transects (table 8), meaning the averaged rate is zero when considered with the uncertainty, indicating no change during the 35-year period used in the analysis. However, keeping in mind that this is an average, 58 percent of the individual transects where rates were calculated measured erosion (table 8). Note that the percent eroding columns in tables 7 and 8 are based on all the individual transects within each littoral cell, even though many of the individual rates are statistically stable. 


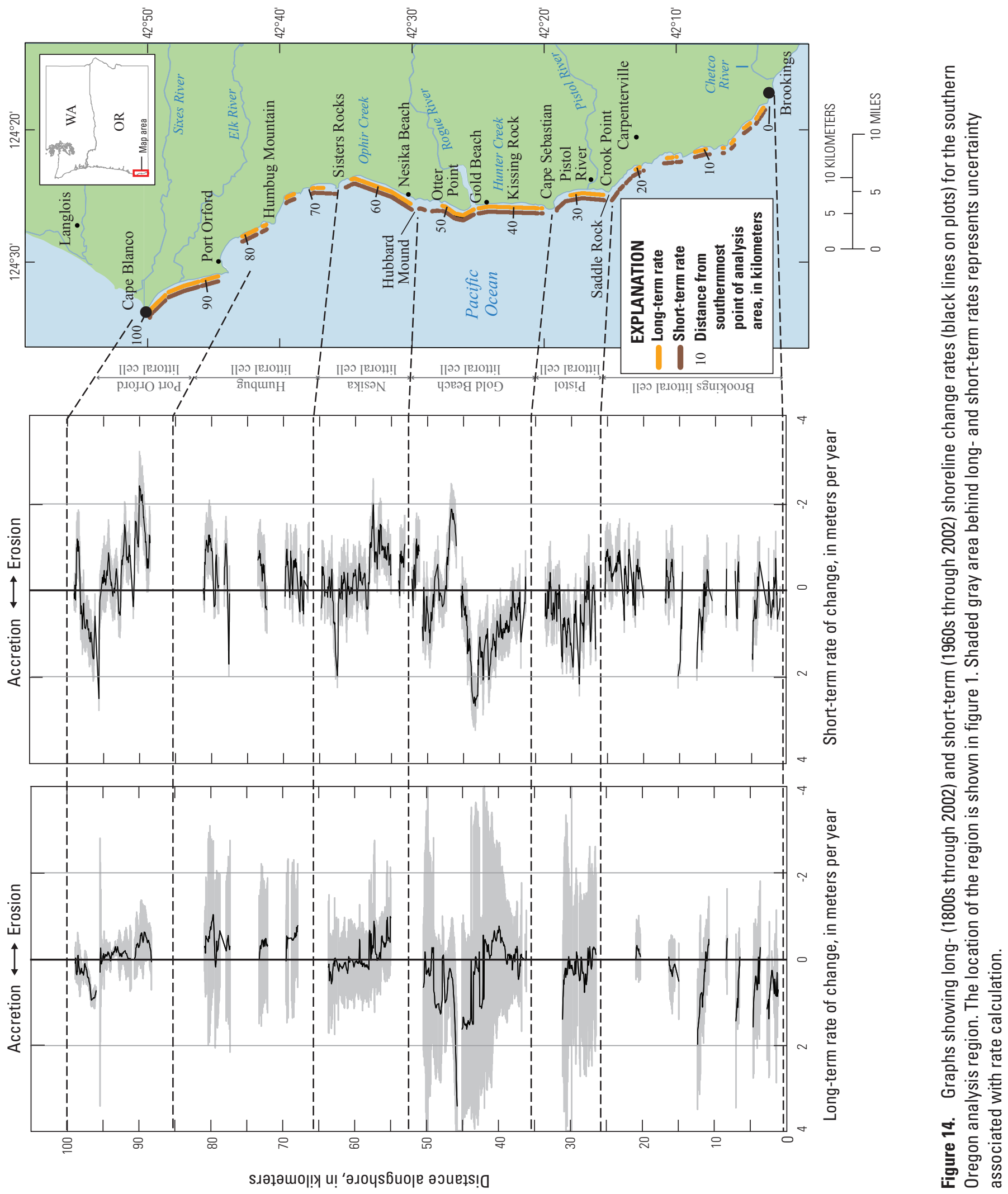


The Pistol littoral cell extends about $8 \mathrm{~km}$ from Crook Point to Cape Sebastian. This littoral cell is sparsely populated and contains the outlet of the Pistol River into the Pacific Ocean. In the long term, the net shoreline change rate, averaged over 88 transects, was not statistically different than zero (table 7), and change rates ranged from -0.3 to $1.4 \mathrm{~m} / \mathrm{yr}$. However, in the short term, the average rate was $0.5 \mathrm{~m} / \mathrm{yr}$ averaged over 133 transects, with only 14 percent of the transects eroding (table 8).

The Gold Beach littoral cell extends about $15 \mathrm{~km}$ from Cape Sebastian to Hubbard Mound and includes the community of Gold Beach and the mouth of the jettied Rogue River (fig. 2). The littoral cell consists of two subcells, one of which includes the shoreline south of the Rogue River, and the other is the area north of the river. Although sediment likely bypasses the Rogue River jetties, enabling sand exchange between the two subcells, it is unlikely that sediment enters the cell from the south (around Cape Sebastian). However, it is possible that sediment may leak around Otter Point, supplying the beaches to the north. For almost the entire length of the
Gold Beach cell, the beaches are backed by a foredune of varying dimensions, with remnant sea cliffs further landward of the dunes, particularly along the shore north of the Rogue River (Allan and Stimely, in press). Due to a broad assortment of grain sizes, the morphology of the beach along the Gold Beach cell ranges from being steep and reflective to an intermediate category beach state using the classification of Wright and Short (1983). Hunter Creek periodically experiences large shoreline excursions (fig. 15) that may vary spatially by as much as about $1 \mathrm{~km}$ from its most northern position to its most southern position, which typically abuts against Kissing Rock (fig. 14). These variations are driven by a combination of riverine discharge and sand accumulation at the mouth of the creek. Migration of this sediment is due to variations in wave energy, which drives the longshore currents that transport sand.

In the long term, the Gold Beach shoreline change rate ranges from -0.8 to $3.4 \mathrm{~m} / \mathrm{yr}$, whereas the average is not statistically different than zero. Of the 246 transects analyzed, 40 percent was eroding (table 7). In the short term, the Gold

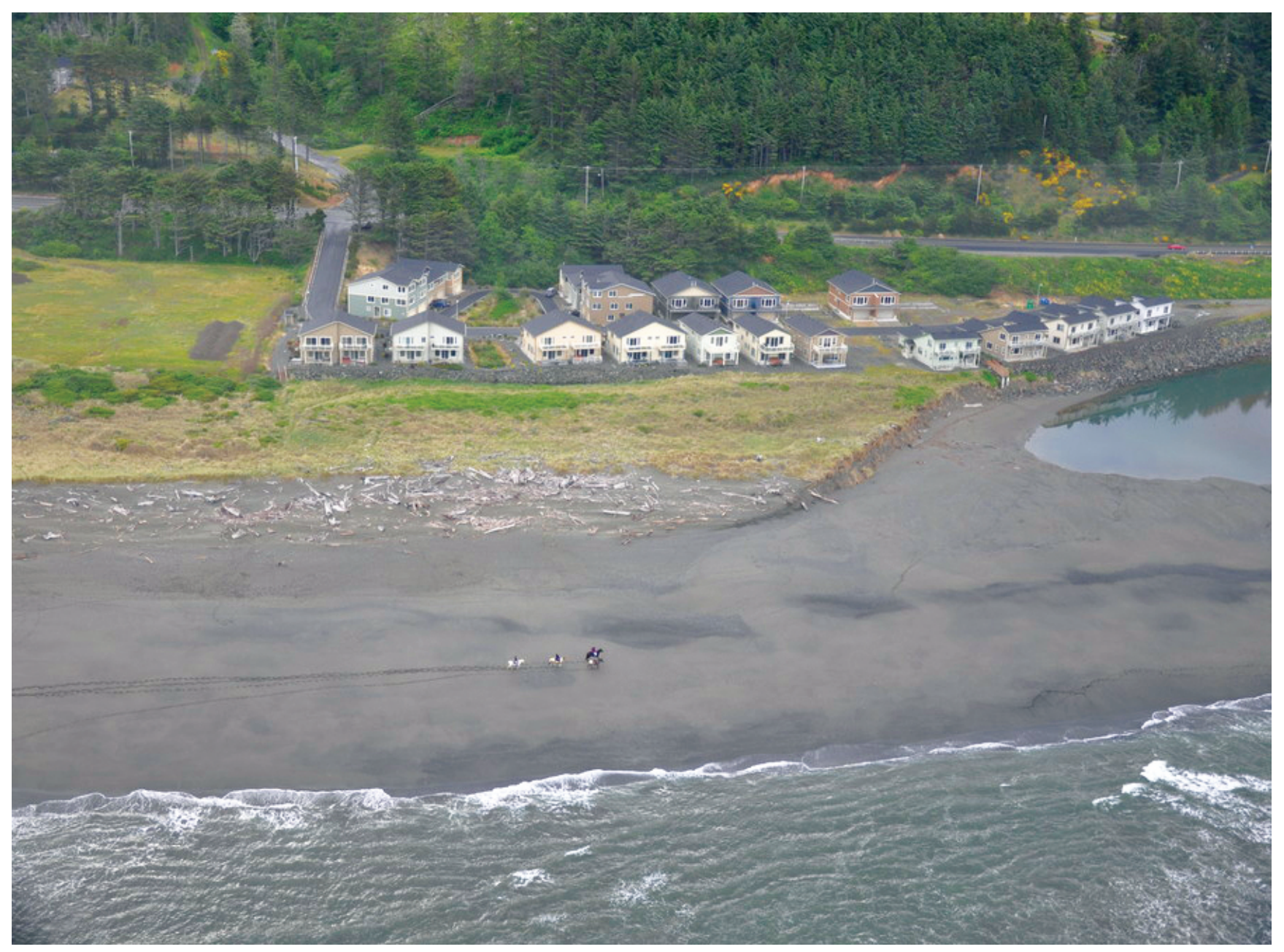

Figure 15. Oblique aerial view of Hunter Creek, Oregon, in the Gold Beach littoral cell. The creek periodically migrates north and jeopardizes development in the area. The photograph is taken looking toward the west. The general location of the site is shown in figure 2. Photograph copyright Oregon ShoreZone imaging project (http://www.coastalatlas.net/shorezone/) photograph 14217. 
Beach shoreline prograded at a rate of $0.6 \mathrm{~m} / \mathrm{yr}$ (table 8), ranging from -1.9 to $2.7 \mathrm{~m} / \mathrm{yr}$. Much of this accretion is a result of sediment impoundment on the south side of the Rogue River Southern Jetty, which was completed in 1960. Of the 270 transects, 22 percent was eroding, with 10 percent of those transects eroding at rates faster than $-1 \mathrm{~m} / \mathrm{yr}$. Most of these higher rates of erosion occurred north of the Rogue River North Jetty (fig. 14).

The Nesika cell extends from Hubbard Mound to Sisters Rocks just north of Ophir Creek (fig. 2). Along much of the shore, the beach is backed by prominent cliffs of Pleistocene marine terrace deposits overlying sheared Jurassic sedimentary (mudstone and sandstone) rocks that are currently being eroded. Estimates of erosion by Priest and others (2004) indicate that the Nesika Beach bluffs are eroding at a rate of about $0.6 \mathrm{~m} / \mathrm{yr}$, which represent some of the highest bluff toe erosion rates measured on the Oregon coast. The geomorphology of the Nesika cell can be broadly classified into three different beach types. At Nesika Beach, the beach sediments are generally fine grained, whereas the back of the beach may be nominally protected by a coarser lag of cobbles to boulders. The beach face is gently sloping and is interspersed with rock outcrops and offshore reefs. Between Nesika Beach and Ophir Creek, the beach sediments coarsen significantly becoming more mixed sand and gravel. As a result, the beach slope is generally steep and the waves typically break directly on the beach face. North of Ophir Creek, the beach sediments become finer grained and the slopes of the beach decreases, whereas the nearshore surf zone widens significantly (Allan and Stimely, in press).

In the long term, the average shoreline change rate in the Nesika littoral cell is not statistically different than zero. Of the 171 transects analyzed, 36 percent was eroding (table 7). In the short term, the Nesika cell shoreline was eroding at a rate of $-0.4 \mathrm{~m} / \mathrm{yr}$ with 75 percent of the 205 analyzed transects containing erosional rates. Thirteen percent of the transects was eroding faster than $-1 \mathrm{~m} / \mathrm{yr}$ (table 8 ).

The Humbug littoral cell extends from Sisters Rocks to Port Orford and, other than the south facing part of Port Orford, is sparsely populated. This littoral cell has a predominately rocky coastline with small sections of pocket beaches. Due to the range of grain sizes, the morphology of the beach within the cell ranges from being steep and reflective to an intermediate category beach state using the classification of Wright and Short (1983). As a result of this geomorphology, there are large sections of this cell that this report does not cover, and only 95 transects were analyzed for the long-term analysis, and 128 transects, for the shortterm analysis (tables 7 and 8). For both analysis periods, the average net shoreline change rate for this littoral cell was $-0.4 \mathrm{~m} / \mathrm{yr}$. Ninety-four percent of the long-term transects was erosional, whereas 79 percent was eroding in the short term. However, in the long term, only 2 percent of the transects was eroding more rapidly than $-1 \mathrm{~m} / \mathrm{yr}$, whereas in the short-term, 11 percent of the transects was eroding faster than this rate.
The most northward littoral cell in the southern Oregon analysis region is the Port Orford cell, extending between Port Orford and Cape Blanco (fig. 2). In the long term, the Port Orford littoral cell shoreline change rate was not statistically different than zero (table 7). In the short-term, the shoreline change rate, averaged over 195 transects, was $-0.3 \mathrm{~m} / \mathrm{yr}$. Sixty-five percent of the transects was eroding, and 24 percent of the transects was eroding faster than $-1 \mathrm{~m} / \mathrm{yr}$ (table 8). The erosion immediately north of Port Orford during the short-term analysis period is consistent with hotspot El Niñoinduced erosion. In the southern Oregon analysis region, none of the transects were eroding faster than $-3 \mathrm{~m} / \mathrm{yr}$ in either the long- or short term.

\section{Bandon-Cape Blanco to Cape Arago}

The Bandon analysis region extends about $50 \mathrm{~km}$ between Cape Blanco and Cape Arago, consisting of only one large littoral cell (fig. 16). Based on geology and geomorphology, the Bandon analysis region can be broadly divided into five morphological beach types, including barrier beaches (for example New River Spit), dune-backed beaches, bluff-backed beaches, dune- and bluff-backed beaches, and plunging cliffs. Beach morphodynamics along the present-day Bandon shoreline are partly a function of the response of the coast to tectonics, with the coast now being emergent relative to sea level rise, and to human-induced effects, such as those associated with the construction of the Coquille jetties. The region most likely experienced extensive erosion when this stretch of shore abruptly subsided at the time of the most recent CSZ earthquake (on January 26, 1700), evident from the presence of the offshore sea stacks at Bandon (fig. 17), but due to its subsequent tectonic uplift, the previously eroded sea cliff is now well vegetated and shows no recent history of erosion effects (Komar and Shih, 1993). The jetties were constructed in the late 1800s at the mouth of the Coquille River, resulting in significant changes to the adjacent shoreline.

The primary sediment sources for the Bandon beaches are fine sands that are carried down the Coquille River and gravels (sand to pebbles) supplied by the erosion of Blacklock Point, located to the north of Cape Blanco. An alongshore variation in the grain size of beach sediment, decreasing to the north due to the Blacklock Point source in the south, has been important to the parallel variations in surf-zone processes and erosion effects (Komar and others, 2001). Aeolian processes have carried fine-grained sand inland where it has accumulated and formed dunes; this beach sediment loss is particularly notable south of Bradley Lake near Bandon where a field of dunes has formed. Sand dunes have also accumulated at the back of the beach along the length of the New River Spit, a ridge of foredunes that separates the ocean beach from the channel of the river. The mouth of the New River has been migrating to the north, shifting zones of erosion versus accretion in areas experiencing the growth of foredunes (Komar and others, 2001). 

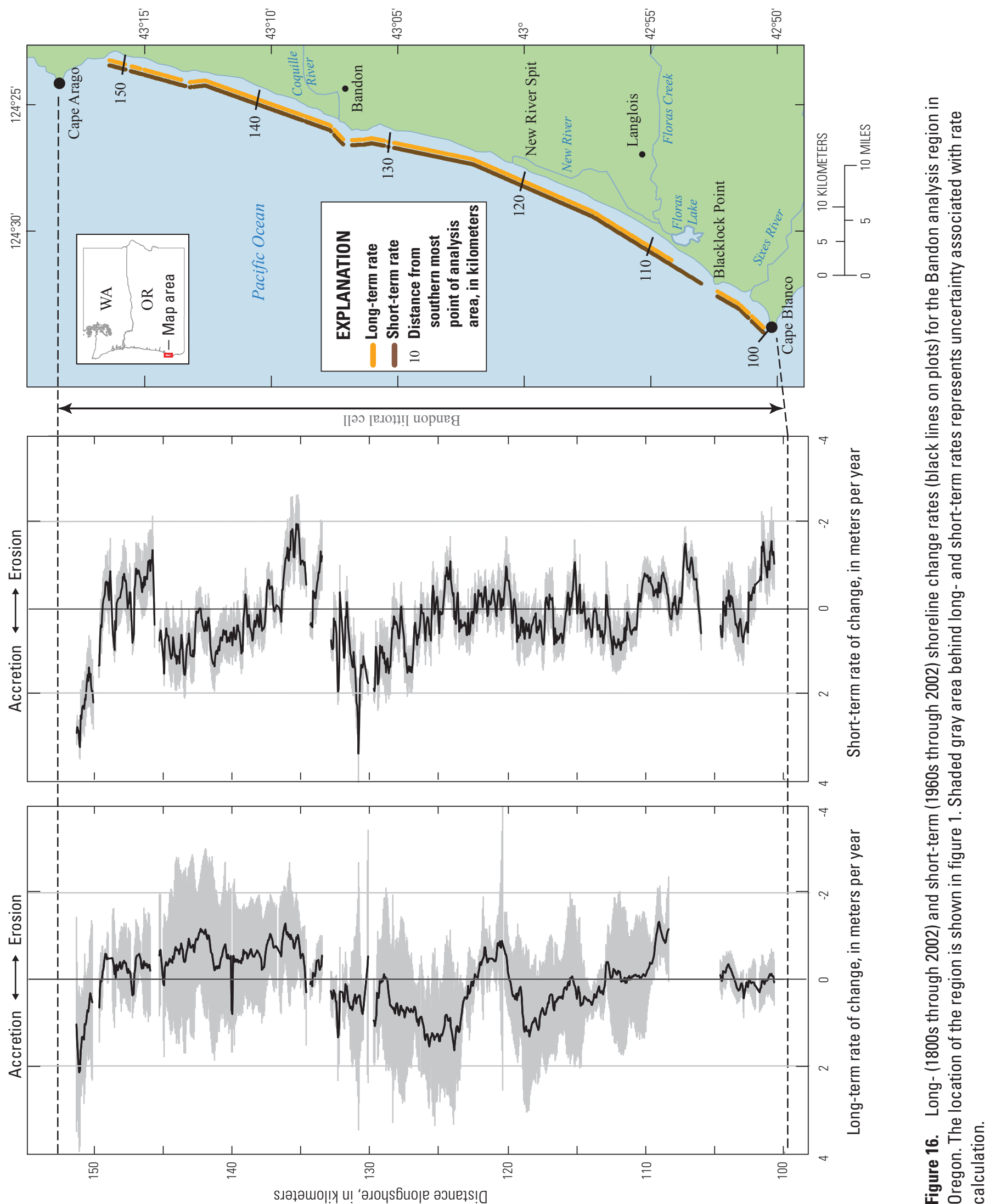


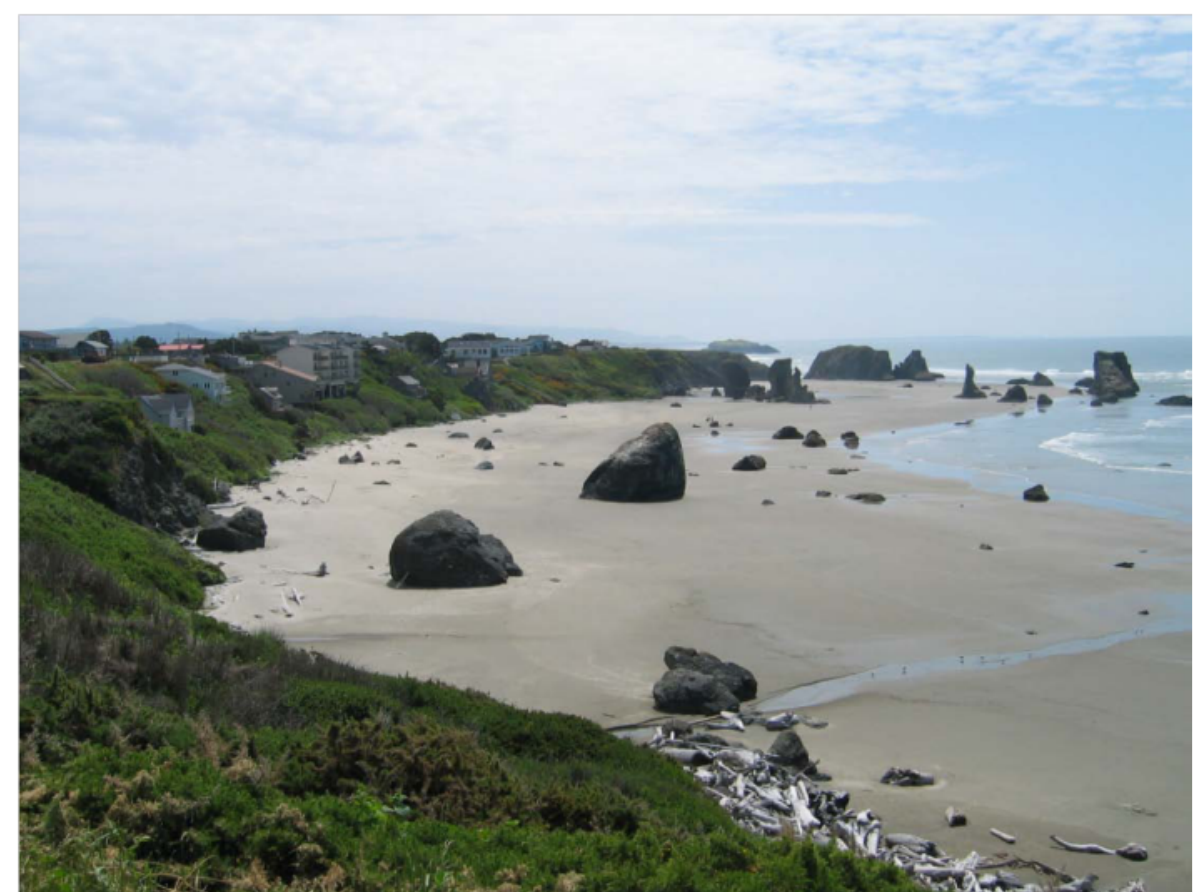

Figure 17. A bluff-backed beach of the type that characterize much of the shoreline near Bandon, Oregon. Note the well-vegetated bluff face indicating stability because impact by waves at the toe of the bluff is rare at this location. Photograph by Jonathan Allan, Oregon Department of Geology and Mineral Industries.
In the long term, the shoreline change rate in the Bandon analysis region ranged from -1.3 to $2.2 \mathrm{~m} / \mathrm{yr}$ (table 7 ), whereas the alongshore averaged mean is not statistically different than zero. Of the 857 transects analyzed, 52 percent was eroding, and 5 percent was eroding at a rate of more than $-1 \mathrm{~m} / \mathrm{yr}$ (table 7 ). However, the influence of the jetties is clearly evident in the long-term shoreline change patterns, particularly in the significant progradation south of the Bandon jetties. In the short term, the Bandon analysis region has been accreting at a rate of $0.2 \mathrm{~m} / \mathrm{yr}$ averaged over 920 transects. Thirty-nine percent of these transects is eroding, and 6 percent is eroding faster than $-1 \mathrm{~m} / \mathrm{yr}$ (table 8 ). The jetty influence is still apparent in the short-term shoreline change signal with impoundment on the south side of the Coquille River and erosion to the north. The maximum short-term shoreline accretion rate of $3.4 \mathrm{~m} / \mathrm{yr}$ and the maximum short-term erosion rate of $-2 \mathrm{~m} / \mathrm{yr}$ occurred just south and north of the river respectively (fig. 16; table 8).

\section{Coos Bay-Cape Arago to Cape Perpetua}

The Coos Bay analysis region (fig. 18) extends about $110 \mathrm{~km}$ between Cape Arago and Cape Perpetua and contains two littoral cells - Coos and Heceta. The Coos littoral cell is primarily made up of wide, straight beaches punctuated by three large estuaries and associated river mouthsCoos Bay, Winchester Bay, and the Siuslaw River Estuary (fig. 2). The Coos Bay dune sheet (fig. 19) is the largest dune accumulation in the United States, extending from Coos Bay to Heceta Head.
Prior to the construction of the Coos Bay jetties, the entrance to the bay consisted of a rocky stretch of coast along its southern bank, with an extensive barrier spit to the north that protected the estuary of the bay from the direct effects of ocean waves. Jetty construction started first on the northern spit; by the beginning of the 20th century, the shoreline had prograded seaward by about $1 \mathrm{~km}$ as sand piled up against the northern jetty. With the construction of the southern jetty early in the 20th century, a similar response was observed in the south as to the north. Sand accreted against the jetty and against the rocky shore, and the shoreline prograded seaward until the 1960s. However, the short-term shoreline change rate immediately north of the northern jetty indicates relatively high rates of erosion.

Komar and others (1976) have documented the shoreline change patterns following the construction of the Siuslaw jetties (constructed between 1891 and 1915) near Florence, Oreg. The shoreline before construction of the jetties curved inward toward the river mouth; the construction of the jetties caused local embayments on both sides. The fact that, in this littoral cell, as in many in the PNW, there is no significant net longshore transport (the huge gross transports balance annually) has resulted in the accretion on both the northern and southern sides of the jetties. Adding to the findings of Komar and others (1976), the effects of the jetties on shoreline change patterns have continued to be recorded in our shortterm shoreline change analysis period (that is, after 1967). The long-term shoreline change rates near the Umpqua jetties at the mouth of the Umpqua River show more or less the same effect as those at the Siuslaw jetties. At the mouth of the 

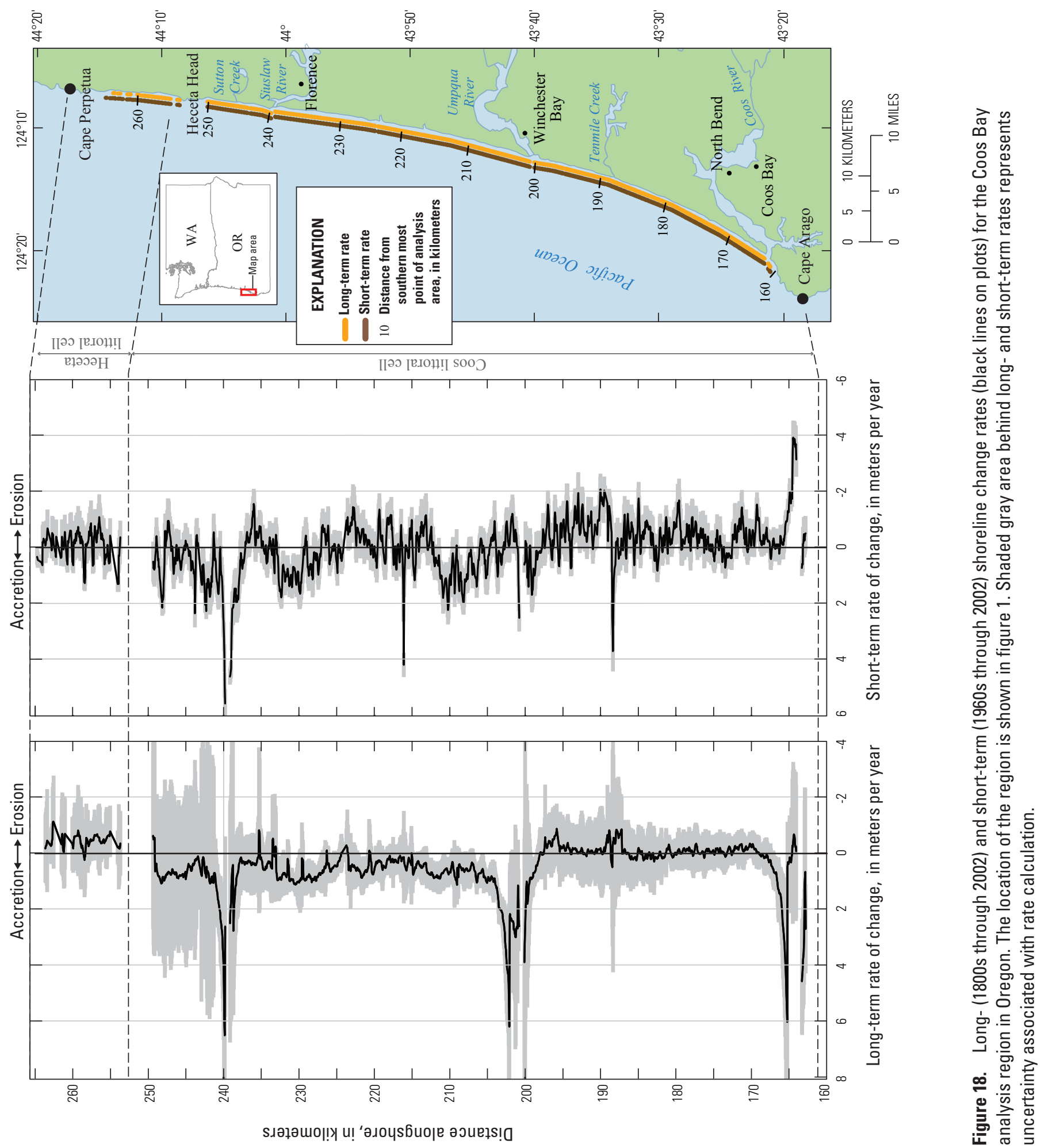


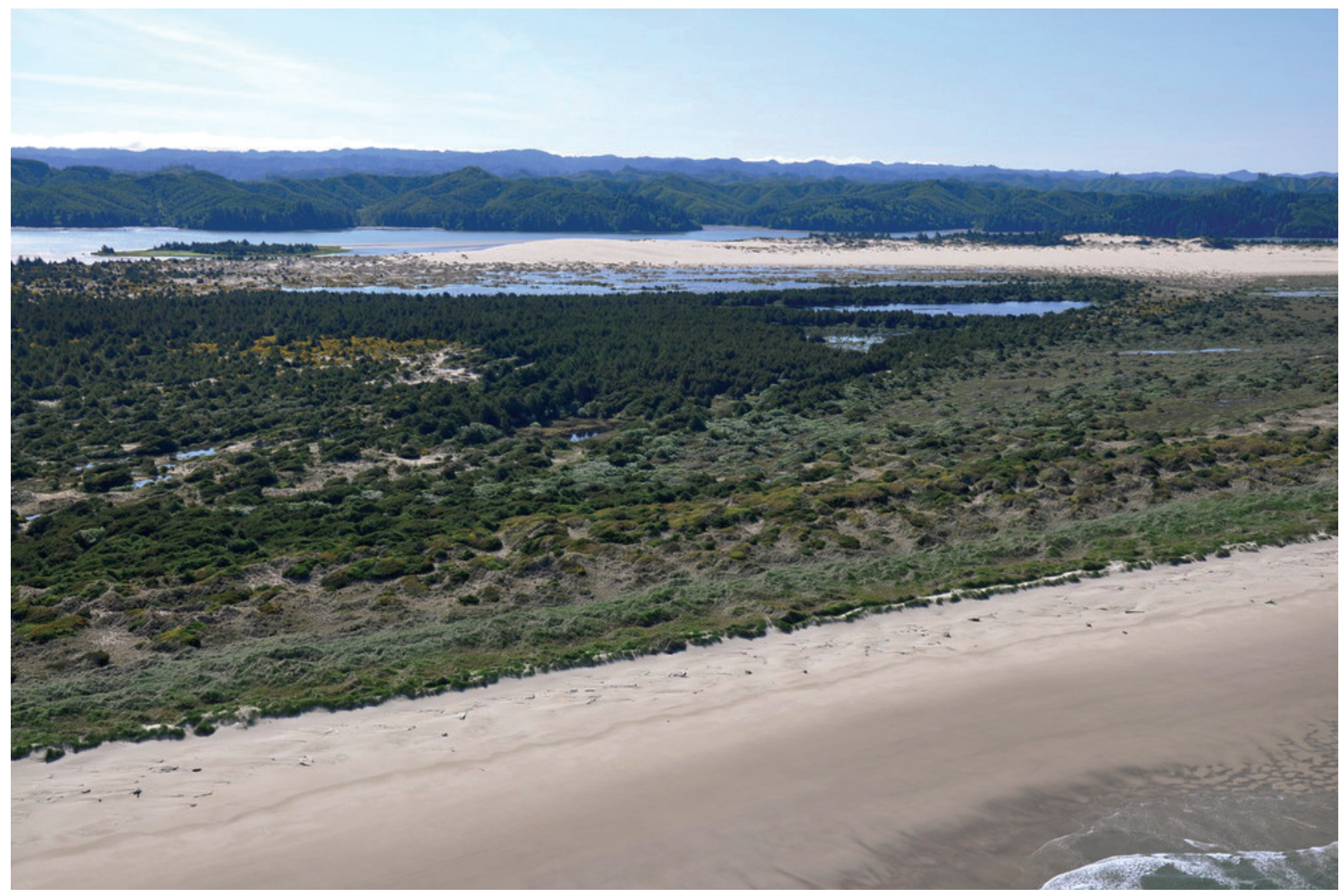

Figure 19. Oblique aerial view of the Coos Bay dune sheet in Oregon. Photograph is taken looking toward the southeast. General location of the site is shown in figure 1. Photograph copyright Oregon ShoreZone imaging project (http://www.coastalatlas.net/ shorezone/ photograph 08149).

Umpqua River, the northern jetty was constructed between 1916 and 1919, and the southern jetty was completed in 1934.

Most likely as a result of the construction of three sets of jetties at the mouths of Coos Bay, the Umpqua River, and the Siuslaw River, the long-term shoreline change in the Coos Bay littoral cell was progradational (fig. 18) at a rate of $0.5 \mathrm{~m} / \mathrm{yr}$ (table 7) averaged over 1,641 transects ( $82 \mathrm{~km}$ of shoreline). Shoreline change rates ranged from -0.9 to $6.5 \mathrm{~m} / \mathrm{yr}$ (table 7 ), and only 26 percent of the transects was eroding, none more than $-1 \mathrm{~m} / \mathrm{yr}$. Following decades of equilibration due to jetty construction, the short-term shoreline change rate, averaged over 1,652 transects, was not statistically different than zero. About half of the transects were eroding, with 8 percent eroding at rates greater than $-1 \mathrm{~m} / \mathrm{yr}$ (table 8 ).

The Heceta littoral cell is relatively small, little more than $10 \mathrm{~km}$, and not populated. It extends between Heceta Head and Cape Perpetua. In the long term, this cell was eroding at an average rate of $-0.4 \mathrm{~m} / \mathrm{yr}$, whereas in the short term, the rate was not statistically different than zero. In the long term, 97 percent of the 115 transects analyzed was eroding (table 7). In the short term, 66 percent of 151 transects was eroding (table 8).

\section{Lincoln County-Cape Perpetua to Cascade Head}

The Lincoln County analysis region extends about $90 \mathrm{~km}$ between Cape Perpetua and Cascade Head (fig. 20). This region contains three littoral cells-Newport, Beverly, and Lincoln.

The Newport cell contains two estuaries, Alsea Bay and Yaquina Bay, as well as the communities of Newport, Seal Rock, Waldport, and Yachats (fig. 2). In the immediate vicinity of both Alsea Bay and Yaquina Bay, the beaches are backed by dunes, whereas the remainder of the littoral cell is backed by coastal bluffs and marine terraces. Jetty construction at Yaquina Bay in 1896 caused significant effects to shoreline change patterns. Komar and others (1976) documented the accretion that occurred between 1899 and 1974, with most accretion south of the jetties. They attributed the large accretion at South Beach to the southwestern trend of the jetties that more effectively shields South Beach from wave attack. Long- and short-term shoreline change rates demonstrate that this pattern has continued throughout the 20th century (fig. 20). 


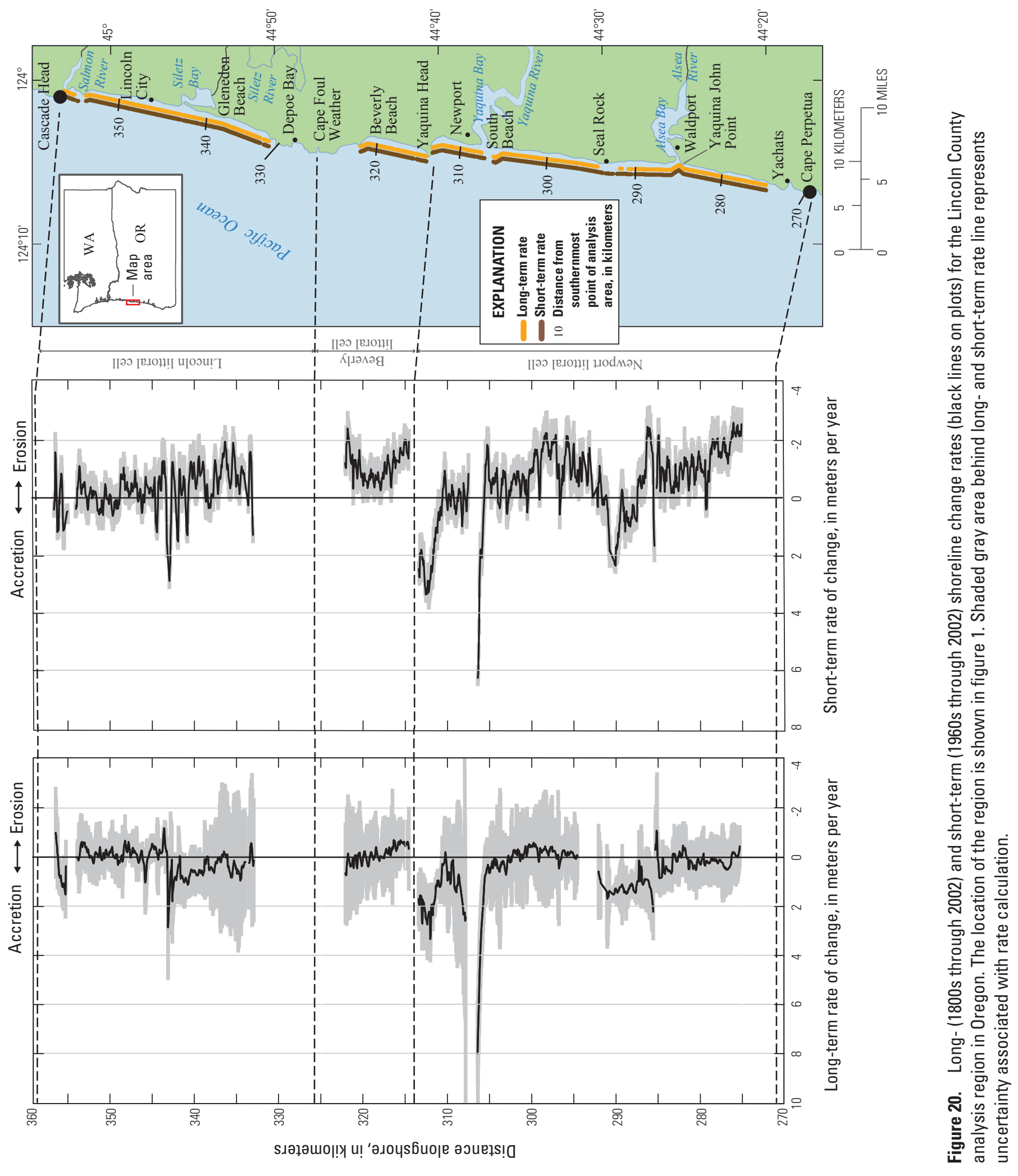


Changes occurred to Alsea Spit during the 1982-3 El Niño when storm-driven waves and nearshore currents changed the channel configuration of the mouth of Alsea Bay (Komar, 1986). The typical configuration of the spit confines the narrow inlet at the mouth of Alsea Bay along the bluffs at Yaquina John Point with the offshore channel continuing directly westward (fig. 21A). However, construction of an underwater sand bar west of the mouth during the 1982-3 El Niño deflected the offshore channel northward, which led to severe erosion of the spit (fig. 21B). The bar grew northward due to storm waves arriving from the southwest (Komar, 1986). Property losses on the spit occurred far north of the inlet and continued for about 3 years as a result of erosion by storm waves that continued to propagate through the deflected channel unhindered by the offshore bar. Emergency measures allowed extensive riprap installation to mitigate the effect of the erosion, but undeveloped lots that lacked shore protection led to further losses. During the decade following the effects of the 1982-3 El Niño, sand returned to the beach to the extent that the sand buried the riprap revetment and threatened to bury nearby houses. The advent of the 1997-8 El Nino resulted in a return of the erosion, threatening new houses that inadvertently had been constructed on the reformed dunes seaward of the buried revetment, requiring the construction of a second revetment. Further beach accretion during the past decade has again led to the burial of the riprap by active sand dunes.

In the long term, the shoreline change rate in the Newport littoral cell, averaged over 622 transects (about $31 \mathrm{~km}$ of shoreline), was $0.5 \mathrm{~m} / \mathrm{yr}$, and only 30 percent of the transects was eroding (table 7). Long-term shoreline change rates ranged from -1.1 to $8.0 \mathrm{~m} / \mathrm{yr}$. In the short term, the shoreline change trend in the Newport littoral cell was reversed. During this period the shoreline change rate, averaged over 686 transects, was eroding at $-0.5 \mathrm{~m} / \mathrm{yr}$, and again was highly variable, ranging from -2.6 to $6.3 \mathrm{~m} / \mathrm{yr}$. Seventy-three percent of the transects showed erosion, and a third of the transects was eroding at rates faster than $-1 \mathrm{~m} / \mathrm{yr}$ (table 8 ). Interestingly,
$\boldsymbol{A}$

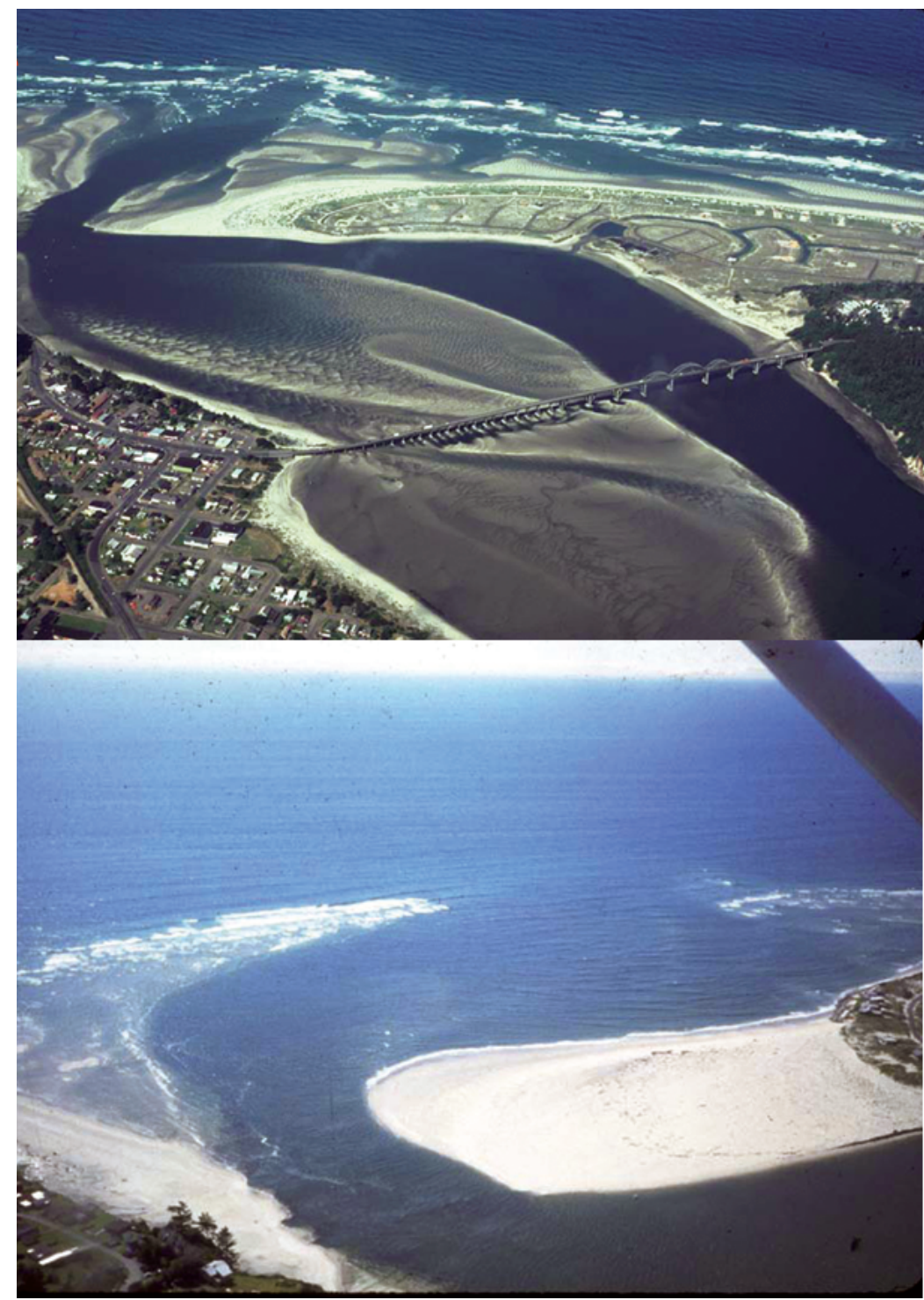

Figure 21. Photographs of Alsea Spit, Oregon; taken by Paul Komar Oregon State University. A, Oblique view of the configuration of Alsea Spit in 1978. B, Rapid changes in the configuration of Alsea Spit occurred in response to large storm waves from the southwest during the 1982-3 El Niño. This caused the waves to break at oblique angles relative to the shore, forming strong northward-directed longshore currents that redistributed sediments along the littoral cell. The resulting currents formed a longshore bar that deflected the channel at the mouth of Alsea Bay northward enabling waves to break close to the shore, which resulted in significant erosion to the spit. 
the shoreline change rates show evidence of a beach rotation between Yachats and Waldport, that is, the sediment eroded near Yachats may have been transported northward towards Waldport. This is possibly a net result of the two major El Niños that occurred during the short-term analysis period. Significant shoreline advance is also evident immediately south of Yaquina Head at the northern extent of the Newport cell. Again, this is suggestive of an effect associated with the major El Niño events of 1982-3 and 1997-8.

The Beverly littoral cell, isolated between Yaquina Head and Cape Foulweather, has been recognized as being one of the most sand-starved littoral cells in Oregon because the only source of modern sand to the cell is the local erosion of the bluffs backing the beach. However, the bluffs consist mainly of Tertiary mudstones capped by only a relatively thin layer of Pleistocene terrace sands. In the long term, the shoreline change rate, averaged over 115 transects, is not statistically different than zero even though 68 percent of the transects indicates erosion (table 7). However, in the short term, this cell has one of the highest average erosion rates in Oregon. The rate, averaged over 146 transects ( $7.3 \mathrm{~km}$ of shoreline), was $-1.1 \mathrm{~m} / \mathrm{yr}$. Notably, each of the 146 transects experienced erosion during the short-term analysis period, more than half of which had rates exceeding $-1 \mathrm{~m} / \mathrm{yr}$ (table 8 ).

North of the large Cape Foulweather and a stretch of rocky coast that extends to Depoe Bay, the Lincoln littoral cell reaches about $15 \mathrm{~km}$ north to Cascade Head and is one of the most populated littoral cells in Oregon. Siletz Bay is fronted by Siletz Spit, a barrier spit that extends for a distance of $3.5 \mathrm{~km}$. The remainder of the beaches in this cell are backed by sea cliffs, the erosion of which in the area of Gleneden Beach south of Siletz Spit is now the main source of sand to the beach, adding a coarse-grained sand component to a littoral cell whose beach is otherwise medium-grained sand (Shih and Komar, 1993). Sand carried down the Siletz River is deposited within the bay and represents a minor contribution of sand to the beach. There is marked alongshore variation in the grain size along this littoral cell due to the addition of the coarse-grained sand, which results in alongshore variability in the beach morphology. The beaches fronting Siletz Spit and Gleneden Beach (fig. 2) have the coarsest sand, as a result of the addition of coarse sand and gravel to the beach by sea-cliff erosion, with sizes decreasing to both the north and the south. The coarse-grained beaches are relatively steep and intermediate to reflective in the Wright and Short (1983) classification, whereas the beaches along Lincoln City are low in slope and dissipative. Rip current embayments are more important to cliff erosion on the reflective part of the beach, producing bluff retreat that has a high degree of spatial variability and is episodic. Wave runup during extreme storms is more influential on the dissipative part of the beach, but the waves generally act to remove only the accumulated material brought down to the beach by subaerial processes.

In the long term the shoreline change rate, averaged over 414 transects $(21 \mathrm{~km})$, is not statistically different than zero. However, in the short term, the average rate is $-0.3 \mathrm{~m} / \mathrm{yr}$ with more than 70 percent of the analyzed transects eroding (table 8). One possible explanation for the erosional trend is the reduction of sediment supplied to the beaches in the cell due to extensive shoreline armoring of eroding bluffs. The relatively high rates of shoreline change in the long and short term at about the $343-\mathrm{km}$ mark in figure 20 indicate spit growth during a century-scale time period.

The overall short-term trend of erosion in the Lincoln County analysis region is different than the short-term shoreline change patterns in the three analysis regions to the south (figs. 14, 16, and 18). This may be a reflection of the alongshore variations in relative sea level rise (fig. 10). South of Cape Arago, the rate of tectonic uplift is high, and the land is emergent relative to sea level. Between Cape Arago and approximately the location of Tillamook Head, relative sea level rise rates are between 1 and $2 \mathrm{~mm} / \mathrm{yr}$ (fig. 10).

\section{Tillamook County—Cascade Head to Cape Falcon}

The Tillamook County analysis region extends about $75 \mathrm{~km}$ between Cascade Head and Cape Falcon (fig. 22) and is made up of long sandy beaches interspersed with prominent headlands and steep bluffs. This region contains four littoral cells-Neskowin, Sand Lake, Netarts, and Rockaway (fig. 11). Similar to the Lincoln County analysis region, Tillamook County is within the region of the Oregon coast that is submergent relative to water level changes (fig. 10).

The most significant historical shoreline changes identified in Tillamook County have occurred in response to human activities, particularly as a result of jetty construction during the early part of the 20th century. In particular, jetty construction has had a dramatic influence on the morphology of Bayocean Spit. Jetty-induced erosion in the vicinity of the Cape Meares community (fig. 2) has resulted in significant coastline retreat. In contrast, erosion from jetty construction has been much lower along the Rockaway Beach and Manzanita coastlines. Coastal change adjacent to the nonmodified bay mouths and spit ends has been large in the past. These features are capable of migrating over large distances in response to changes in both the sediment supply and the predominant wave conditions.

The Tillamook County shorelines have also been particularly effected by major El Niño events. Examples of significant hotspot erosion problems along this region include a hotspot area of maximum beach and foredune erosion in Neskowin occurring immediately north of Cascade Head, the erosion and flooding effects to Cape Lookout State Park at the south end of Netarts Spit to the north of Cape Lookout during both the 1982-3 and 1997-8 El Niño events, and effects to development of condominiums constructed on a high sand bluff that was eroded by the northward migration of the inlet to Netarts Bay. To date, many of the beaches on the northern Oregon coast, particularly in Tillamook County, have yet to fully recover from the cumulative effects of the 1997-8 


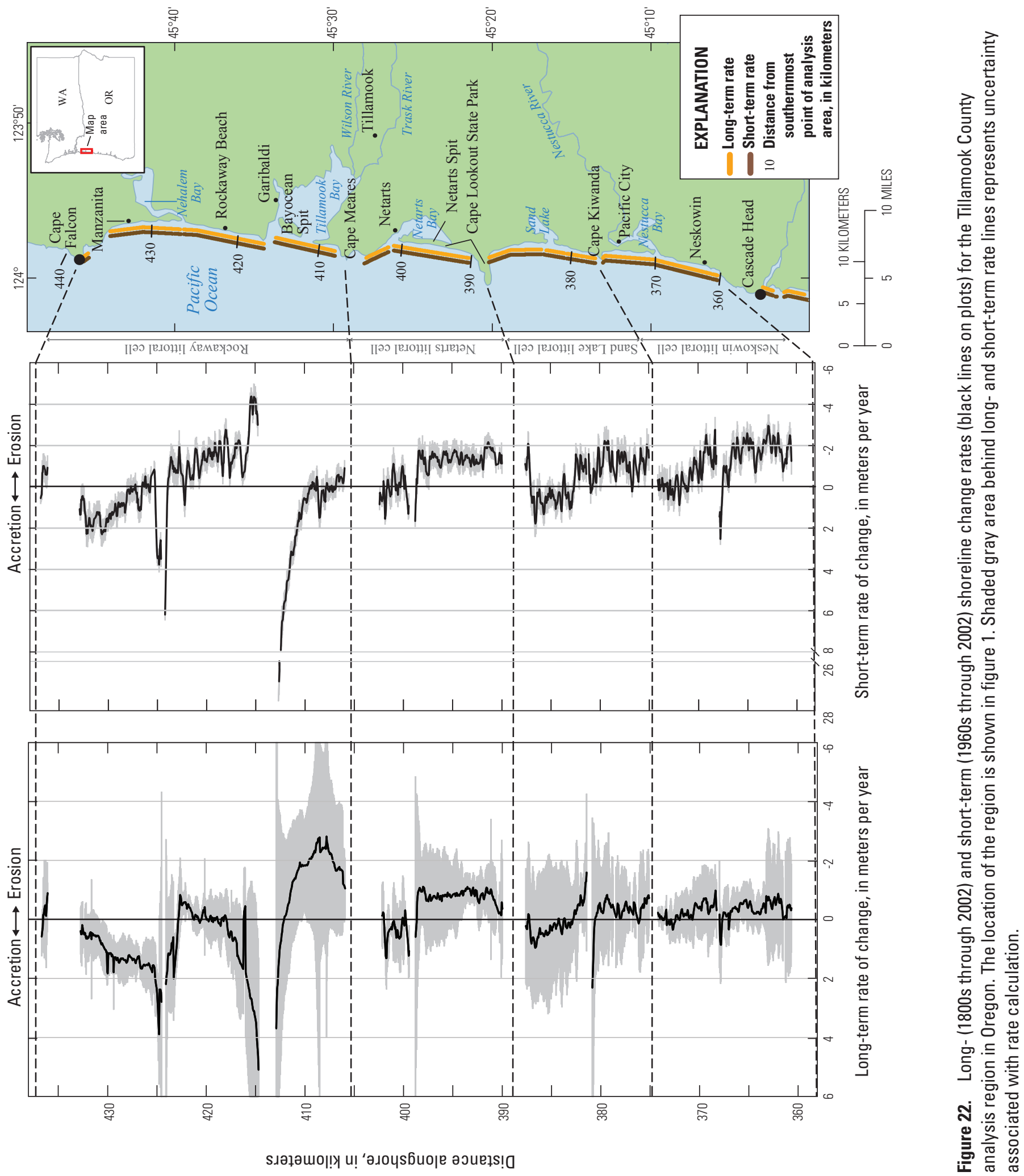


El Niño and the severe winter 1998-9 (Allan and Hart, 2008). As a result, a number of beaches remain in a degraded state, exposing them to future storm-induced flooding and erosion.

The Neskowin littoral cell extends from Cascade Head to Cape Kiwanda and contains the communities of Neskowin and Pacific City as well as the entrance to Nestucca Bay. Erosion has been particularly acute along parts of the Neskowin littoral cell, caused in part by the effects of recent major El Niño events and possibly by the progressive rise in sea level and wave heights in recent decades. Examination of lidar and beach monitoring data for the Neskowin cell shows that the southern end of the cell continued to erode in subsequent years, with some storms having produced as much as $25 \mathrm{~m}$ of dune retreat during a single event (Allan and Hart, 2008).

Today, erosion and flooding along the beaches of Neskowin are being perceived as a harbinger of the possible effects of future climate change for other communities along the Oregon coast. For example, the significant loss of beach that previously protected coastal properties in Neskowin has substantially increased the potential for catastrophic losses during a major storm. The hallmark example of this scenario was a major storm on January 5, 2008, that came close to removing oceanfront homes in Neskowin. Beach elevations had progressively been lowered during winter 2007-8, and the combination of extreme waves during that January storm along with high water levels enabled waves to break close to shore, scouring down the beach face and eventually undermining the toe of a riprap structure and causing part of the structure to fail. As a result, given that many beaches in Tillamook County have recovered very little in the intervening years (in other words, beaches today are narrower and have less sand volume compared with the same beaches in the mid-1990s), the community of Neskowin in particular remains at high risk of being affected by coastal erosion and ocean flooding (Allan and Hart, 2008). Residents in Neskowin have resorted to expensive engineering to safeguard their homes from further coastal hazards. Under Oregon law, the costs to maintain such structures are entirely borne by the individuals. The entire community faces an uncertain future if individual residents become unable to maintain their portion of riprap due to persistent structural failure and increasing repair costs.

The long-term shoreline change rate in the Neskowin littoral cell, averaged over 260 transects $(13 \mathrm{~km})$, is not statistically different than zero even though about 88 percent of the transects measured an erosional trend (table 7). However, in the short term, the Neskowin cell had one of the highest rates of erosion in the State, $-1.1 \mathrm{~m} / \mathrm{yr}$, averaged over 261 transects. Variability in the short term was also relatively high, with change rates ranging from -3.0 to $2.5 \mathrm{~m} / \mathrm{yr}$. Eighty-six percent of the transects was eroding, with 58 percent eroding faster than $-1 \mathrm{~m} / \mathrm{yr}$ (table 8 ). The relative shoreline stability at Pacific City where the dunes are growing (fig. 22) indicates a shoreline rotation possibly associated with El Niño effects.
The Sand Lake littoral cell, extending from Cape Kiwanda to Cape Lookout, is relatively sand rich, particularly at the northern end of the cell where a large dune sheet extends well inland. This cell is sparsely populated and contains the unjettied Sand Lake estuary. North of the estuary is the Sand Lake Recreation Area, which covers more than $4 \mathrm{~km}^{2}$ of open sand dunes (fig. 2). The sand dunes begin at the estuary and extend about $5 \mathrm{~km}$ to the northeast. In the long term, the shoreline change rate in this cell was not statistically different than zero, although large changes near the mouth of Sand Lake estuary (fig. 22) suggest northern spit extension. In the short term, the average shoreline change rate indicates net erosion. Averaged over 232 transects $(11.5 \mathrm{~km})$, the shortterm shoreline change rate was $-0.5 \mathrm{~m} / \mathrm{yr}$, with 63 percent of the transects experiencing erosion (table 8 ). The short-term shoreline change is consistent with shoreline rotation.

The Netarts littoral cell, one of Oregon's smallest littoral cells, is $14 \mathrm{~km}$ long, extending from Cape Lookout in the south to Cape Meares in the north and is the home of Cape Lookout State Park, one of the most popular parks in the State. The major geomorphological feature in the cell is Netarts Spit, extending about $9 \mathrm{~km}$ from the base of Cape Lookout and fronting the relatively shallow Netarts Bay (without a jetty). The spit was breached only once in recorded history during a winter storm of January 1939, which is considered to be one of the worst on record (Paul Komar, [Oregon State University], oral commun., [2008]). Similar to the other cells in Tillamook County, the Netarts littoral cell is extremely vulnerable to major El Niño events. Since the 1982-3 El Niño, this cell, particularly its southern end, has experienced significant erosion problems. Revell and others (2002) used lidar data to document the cellwide longshore displacement of the beach sand and the resulting hotspot erosion at the south end of the cell during the 1997-8 El Nino.

Erosion has been particularly severe at Cape Lookout State Park where much of the fronting sand beach was lost, followed by the erosion of a ridge of high dunes that had sheltered the park grounds. A series of major storms during winter 1998-9 eventually breached the remaining dune system, inundating the park and producing considerable damage to park facilities. It was clear that the park would likely incur additional damage during subsequent winters, unless some form of shore protection was installed. Rather than constructing a conventional seawall or riprap revetment, the decision was made to construct a cobble berm backed by an artificial dune (Allan and Komar, 2004).

In the long term, the Netarts littoral cell eroded at a rate of $-0.5 \mathrm{~m} / \mathrm{yr}$ averaged over 220 transects (11 km of shoreline). Eighty percent of the transects demonstrated erosion during this time period (table 7). In the short term, this rate was higher than in the long term at $-1.0 \mathrm{~m} / \mathrm{yr}$, and 86 percent of the transects analyzed was eroding, 69 percent at a rate faster than $-1 \mathrm{~m} / \mathrm{yr}$ (table 8). This is a mostly closed littoral cell, with no sand sources, so the net erosion most likely represents sand carried into Netarts Bay during the El Niños. 
The Rockaway cell, extending about $30 \mathrm{~km}$ from Cape Meares to Cape Falcon, is subdivided by the jettied entrances to Tillamook Bay and Nehalem Bay (fig. 22). Effects from the construction of jetties at the inlets dominate the long-term shoreline change trends. The northern jetty at Tillamook Bay was constructed between 1914 and 1917, and the typical pattern of accretion along the northern side of the jetty ensued. Only a single jetty along the northern side of the inlet was completed, and the beaches along Bayocean spit entered a period of disequilibrium resulting in erosion that led to the destruction of the community of Bayocean (Komar, 1997) and the breaching of the spit at its southern end in 1952. It was not until 1974 that the Tillamook Bay South Jetty was constructed, and the adjacent shoreline is still evolving toward a new equilibrium.

Erosion has become particularly acute along the Rockaway littoral cell (figs. 22, 23, and 24), much of which can be attributed to the extreme storms that affected this section of the coast during winter 1997-8 and winter 1998-9 (Allan and Komar, 2002). The data shown in figure 24 were derived by analyzing topographic beach volume changes collected using airborne lidar data flown in 1997 and 2002. Subsequent monitoring of the beaches indicates that the shoreline has continued to experience ongoing erosion, with the Rockaway Beach area continuing to lose sand over time, whereas Bayocean Spit and parts of the Nehalem Spit appear to be slowly gaining some of this sand (Allan and others,
2009). The net loss of sand from the cell was estimated to be about 2 to 2.5 million cubic meters $\left(\mathrm{Mm}^{3}\right)$ of sand (Allan and Hart, 2008). Parts of the shore immediately north of Tillamook Bay have eroded by as much as $47 \mathrm{~m}$, increasing the hazard potential to existing homes and infrastructure from ocean flooding and additional future shoreline retreat.

Although significant variability exists (change rates ranged from -2.8 to $5.1 \mathrm{~m} / \mathrm{yr}$ ), the net long-term shoreline change rate in the Rockaway cell is not statistically different than zero. Forty percent of the 499 transects $(25 \mathrm{~km})$ was eroding, and 22 percent was eroding faster than $-1 \mathrm{~m} / \mathrm{yr}$ (table 7 ). The short-term shoreline change rate in the Rockaway cell is surprisingly net progradational. Averaged over 500 transects, the cell accreted at a rate of $0.6 \mathrm{~m} / \mathrm{yr}$ (table 8 ). However, this is largely the result of the construction of the Tillamook Bay South Jetty in 1974 and the massive accretion south of this jetty in subsequent years. The greatest statewide short-term rate of shoreline progradation, $26.5 \mathrm{~m} / \mathrm{yr}$, occurs in this cell. However, of note, 25 percent of the analyzed transects eroded at rates faster than $-1 \mathrm{~m} / \mathrm{yr}$, and 3 percent eroded more rapidly than $-3 \mathrm{~m} / \mathrm{yr}$. The Rockaway Beach area of the cell was almost entirely erosional except for some accretion in the immediate vicinity of the Nehalem Bay South Jetty. The combined trends of the Rockaway and Nehalem areas again indicate a counter clockwise shoreline rotation, possibly a result of the two major El Niño events that occurred during the 35-year short-term analysis period.

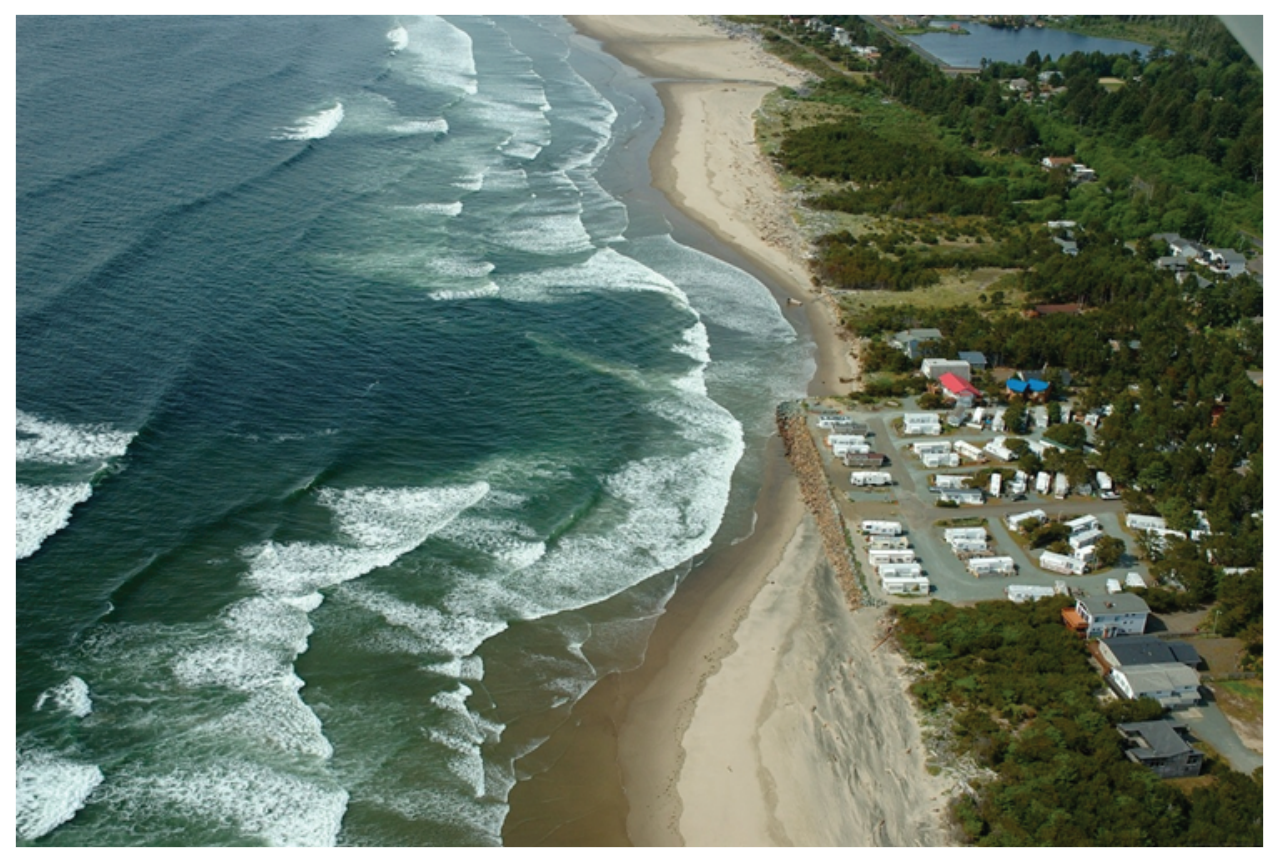

Figure 23. A riprap structure near Rockaway Beach, Oregon. Ongoing shoreline retreat during the past decade in the Rockaway littoral cell and localized hotspot erosion effects have resulted in substantial sections of the shore having to be riprapped in order to safeguard property. Sea level rise expected during the 21 st century is expected to increase the risk of failure of such structures and the potential loss of homes and important infrastructure backing the beach. Photograph courtesy Don Best (2009). 


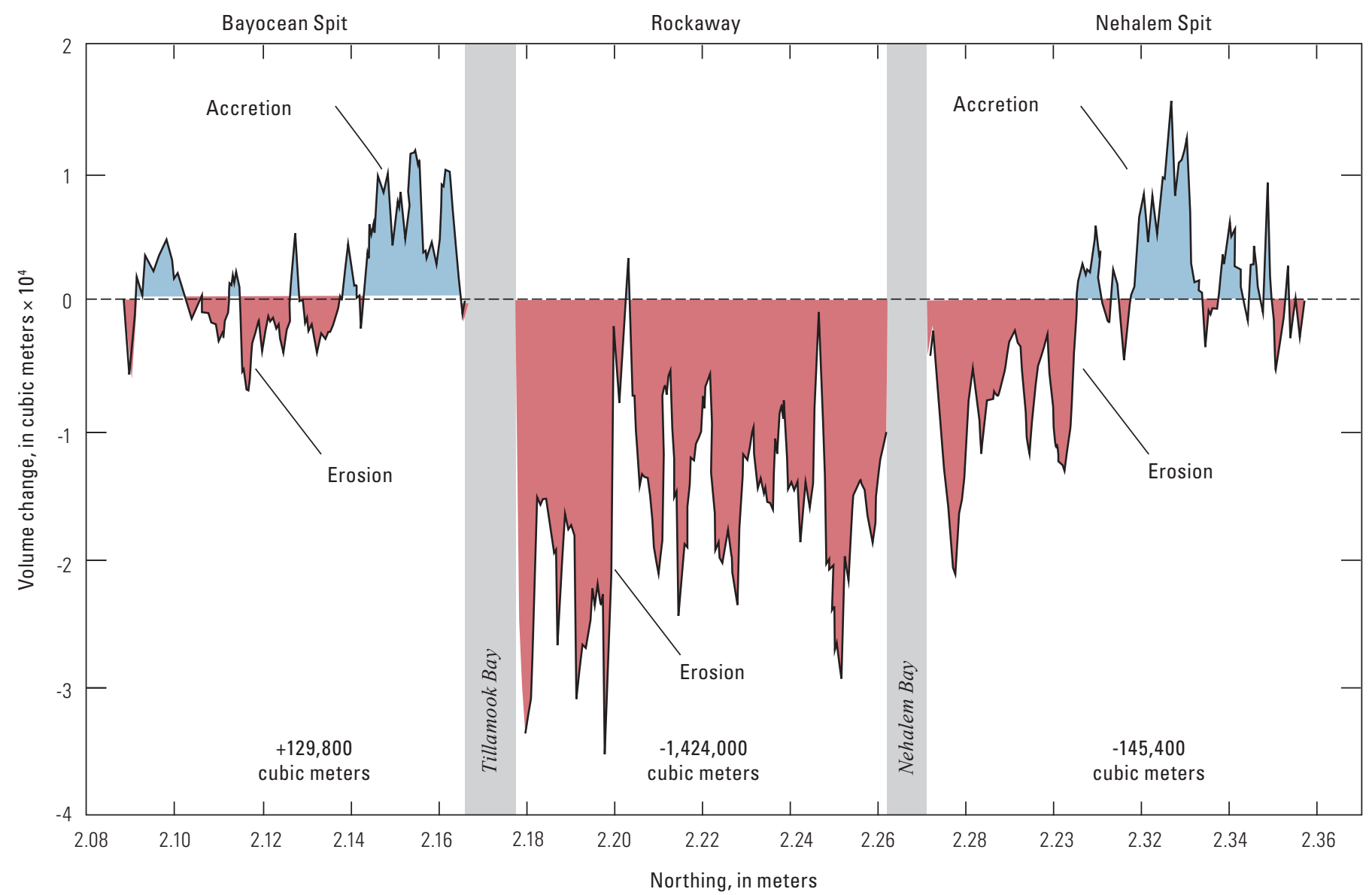

Figure 24. Alongshore variability in beach volume changes derived from an analysis of available lidar data for 1997 through 2002 for the Rockaway littoral cell in Oregon from Allan and others (2009). Red shading indicates erosion, blue shading indicates accretion.

\section{Cannon Beach—Cape Falcon to Tillamook Head}

The Cannon Beach analysis region, which consists of one littoral cell, extends a little more than $15 \mathrm{~km}$ from Cape Falcon to Tillamook Head (fig. 25). The Cannon Beach cell is primarily bluff backed except for the dunes backing beaches along the northern extent of the town of Cannon Beach, north of Ecola Creek. Gravels are also prevalent along much of the Cannon Beach littoral cell shoreline, forming a thin veneer at the back of most of the beaches in southern Cannon Beach, Hug Point, and Arcadia Beach. Progressing south, the gravels increase in size and volume forming a more substantial gravel beach at Arch Cape (fig. 26), culminating with an impressive cobble berm at Falcon Cove. Geomorphically, many of these beaches may be characterized as composite using the terminology of Jennings and Shulmeister (2002), such that the beaches consist of a wide dissipative sandy beach, backed by a steep upper foreshore of gravels. In addition, several of the bluff-backed sections are characterized by well vegetated faces, indicating that they have not been subject to significant wave erosion processes along the toe of the bluff during the late 20th and early 21 st centuries. This littoral cell is at a transition between areas with positive and negative relative sea level rates (fig. 10).

During the long term, the average shoreline change rate in the Cannon Beach littoral cell is not statistically different than zero. Only 35 percent of the 214 transects analyzed (about $11 \mathrm{~km}$ of shoreline) was eroding (table 7). In the short term, the shoreline change rate, averaged over 245 transects, was $-0.5 \mathrm{~m} / \mathrm{yr}$. Seventy-five percent of the analyzed transects was eroding, with 25 percent eroding faster than $-1 \mathrm{~m} / \mathrm{yr}$ (table 8). The southern part of the cell near Arch Cape experienced relatively high erosion rates, whereas the majority of the beaches fronting the community of Cannon Beach were stable (fig. 25). Measurable accretion occurred in the dunebacked area north of Ecola Creek. 


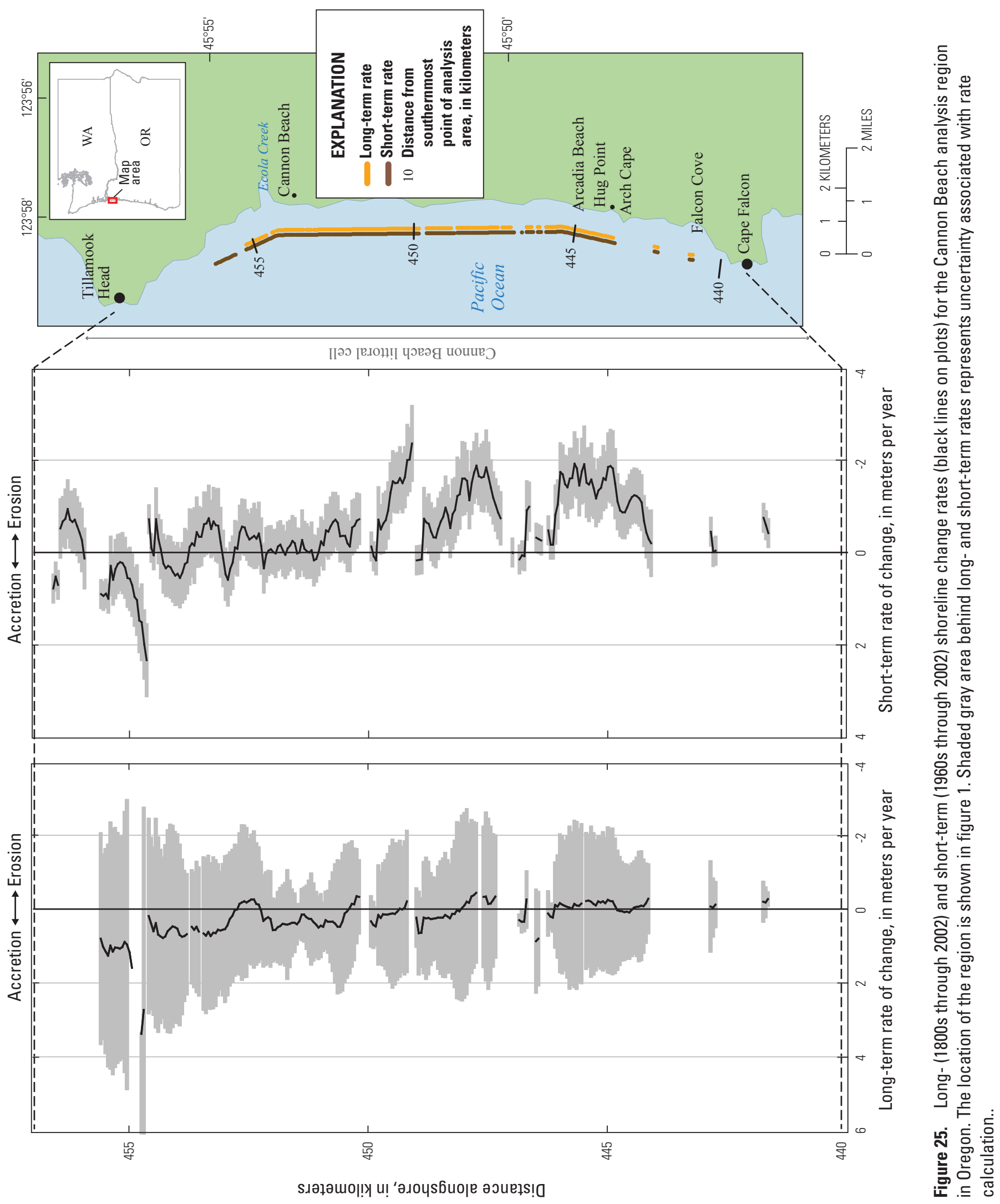




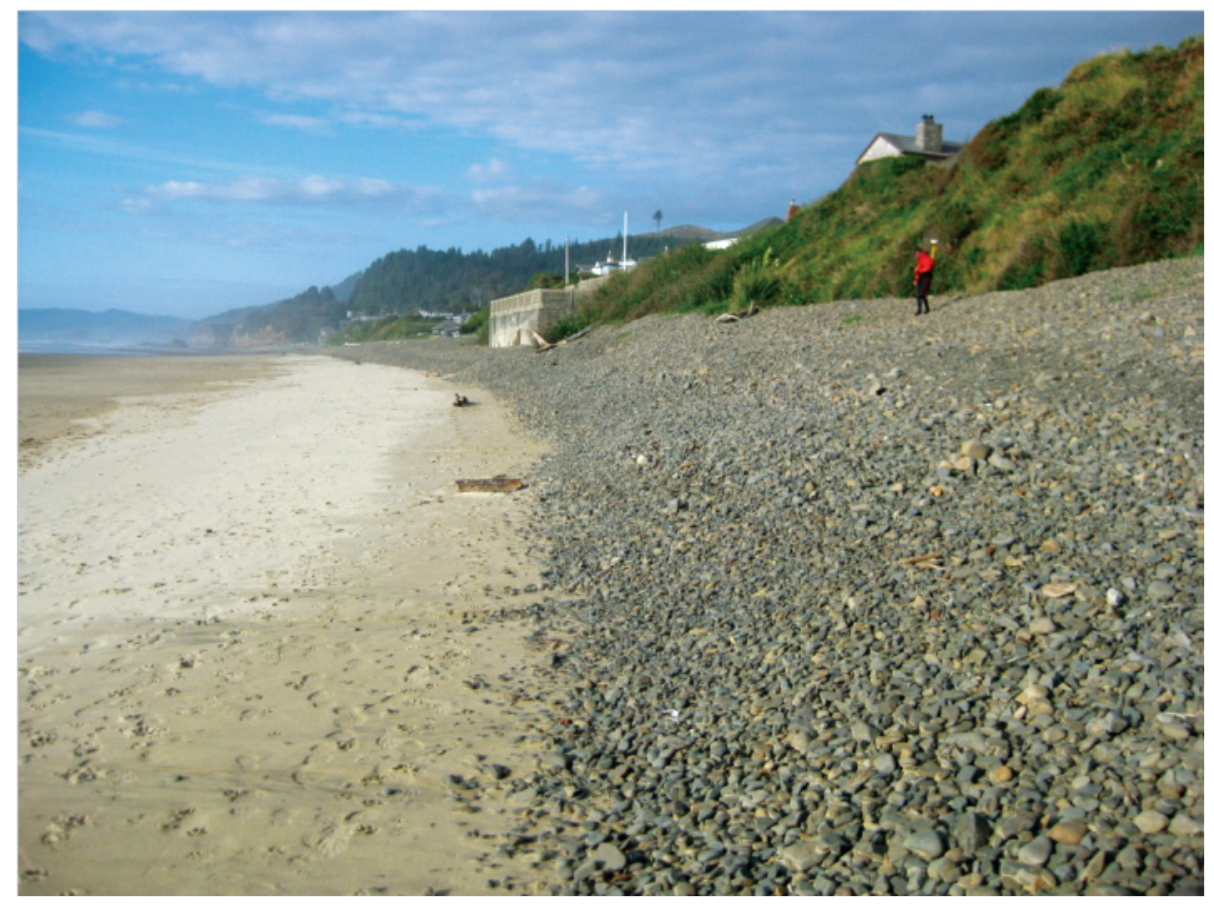

Figure 26. Photograph looking north at Arch Cape, Oregon. The entire beach is backed by a prominent gravel berm containing shingle to cobble size particles and is further backed by low bluffs. The bluff faces exhibit few signs of recent erosion, evident by the well-vegetated bluff face. Note the prominent seawall (middle of the photograph) constructed to protect one particular home. Photograph by Laura Stimely, Oregon Department of Geology and Mineral Industries.

\section{Columbia River Littoral Cell}

The Columbia River littoral cell analysis region extends about $165 \mathrm{~km}$ (fig. 3) between Tillamook Head and Point Grenville and is made up of the CRLC, which consists of four concave-shaped prograded barrier plain subcells separated by the estuary entrances of the Columbia River, Willapa Bay, and Grays Harbor (fig. 27). The CRLC is the geographic extent of where modern Columbia River sediment is deposited on the beaches; the beaches to the south and north of the cell receive insignificant quantities of that sediment (Venkatarathnam and McManus, 1973; Clemens and Komar, 1988). The modern barriers and strand plains (in other words, prograded barrier beaches) of the CRLC were built up sequentially following the filling of the shelf and estuary accommodation space and the onset of a relatively slow rate of eustatic sea-level rise about 6,000 years ago (Peterson and others, 2010b). About 4,500 years ago, Long Beach and Clatsop Plains began to prograde, whereas Grayland Plains began to prograde about 2,800 years ago. The oldest parts of North Beach have sustained net progradation only for the past 2,500 years (Peterson and others, 2010a). The CRLC is the only extensive stretch of shoreline on the PNW coast that has naturally accumulated volumes of sand sufficient for the beach to advance seaward. Wide, gently sloping beaches characterize the region, with sand having been derived from the Columbia River. Broad surf zones with multiple sandbars characterize the modally dissipative (Wright and Short, 1983; Ruggiero and others, 2005) high-energy system. The beaches are backed predominantly by prograded dune fields and swales and by sea cliffs along the northern half of the North Beach subcell.

The evolution of the CRLC since the late 1800s has been marked by large signals of shoreline change (on horizontal scales of meters to kilometers), large signals of bathymetric change (on vertical scales of centimeters to meters), and large transfers of sand (typically on the scales of millions of cubic meters and tens to hundreds of cubic meters per year per meter alongshore). These changes have been primarily caused by the construction of jetties at the entrances to the Columbia River (1885-1913) and Grays Harbor (1898-1916), which established new boundary conditions, modified local sediment supplies, and induced systemwide morphological responses at the decade to century time scale. Kaminsky and others (2010) describe the historical evolution of the CRLC in detail.

The beaches within the CRLC are still evolving from anthropogenic perturbations to the natural system, some of which occurred more than a century ago (Kaminsky and others, 2010). The construction of jetties at the mouth of the Columbia River and at Grays Harbor and the development of the extensive flow control systems on the Columbia River (dams and irrigation) have severely altered the natural sediment supply to the CRLC. The majority of the beaches in the CRLC have responded to these human effects by experiencing dramatic beach progradation during the past century with rates significantly higher than late prehistoric rates, as inferred from CSZ tsunami-induced scarps and T-sheets from the late 1800s (Woxell, 1998; Kaminsky and others, 2010). 


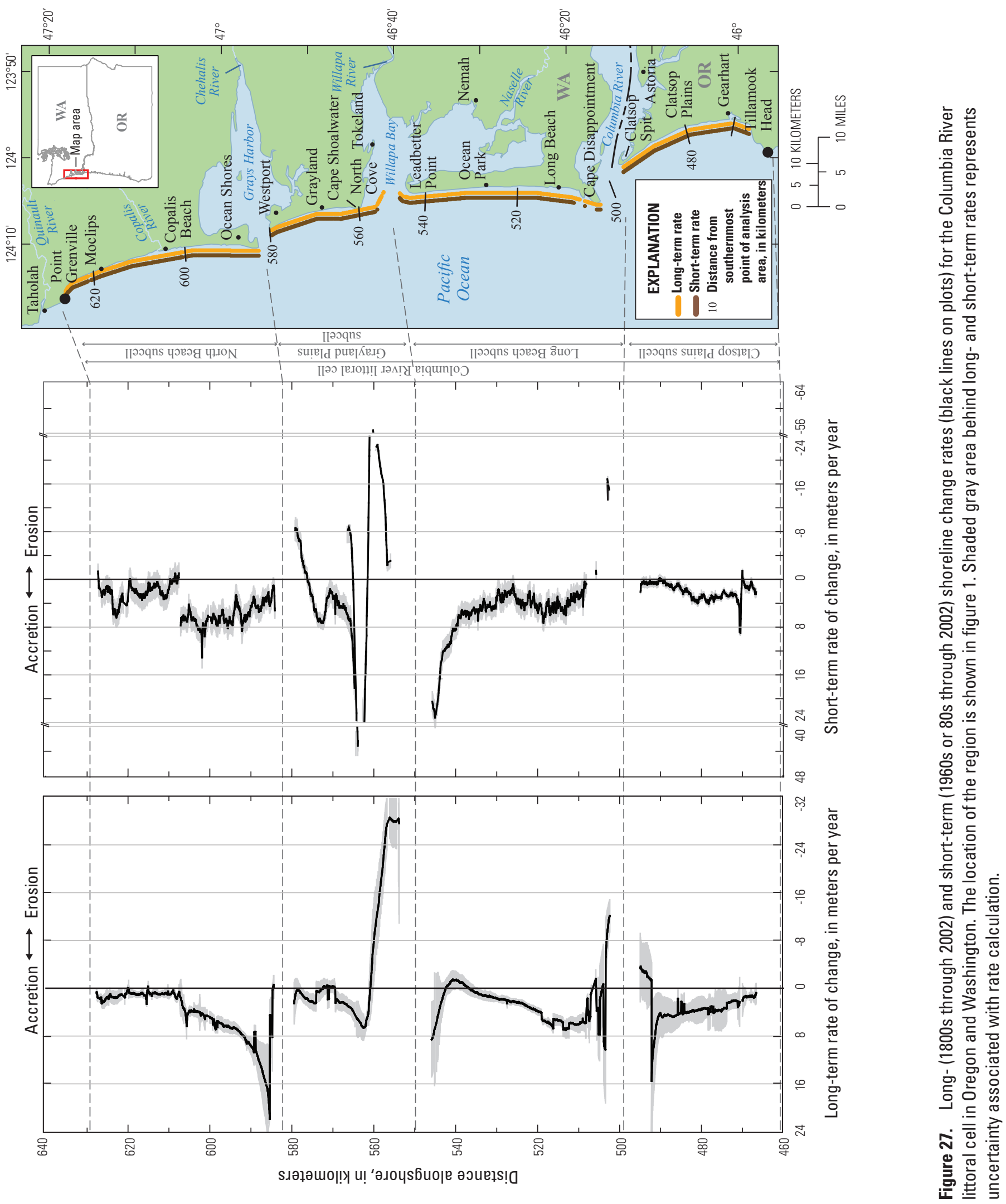




\section{Columbia River Littoral Cell (Clatsop Plains Subcell)— Tillamook Head to the Columbia River}

The Clatsop Plains subcell is an arcuate-shaped coastline, which includes the communities of Seaside and Gearhart, and extends from Tillamook Head in the south to the mouth of the Columbia River (figs. 2 and 28). The Clatsop Plains subcell coastline is characterized by wide, dissipative surf zones and prominent longshore bars in the nearshore, whereas the beaches are backed by an extensive dune sequence (Cooper, 1958; Woxell, 1998; Hacker and others, 2012). The frontal foredunes that immediately back the beaches range in height from about $8 \mathrm{~m}$ to more than $16 \mathrm{~m}$ (relative to mean lower low water datum). These dunes increase in height from Seaside to Kyle Lake and then decrease in height towards Clatsop Spit (fig. 2; Mull, 2011).

Construction of the Columbia River South Jetty began in 1885, and the coastline prograded seaward by hundreds of meters. These changes were not constant, varying in response to different phases of jetty construction, including the construction of the northern jetty and subsequent maintenance and modification (Lockett, 1963). Following completion of the southern jetty in 1902, Clatsop Spit grew northwards by about $4.6 \mathrm{~km}$ during 50 years. Since the mid-1920s, the rate of coastal advance has slowed along much of the Clatsop Plains subcell, except for the northern end of the spit, which experienced erosion up until the 1950s. Ongoing erosion offshore from Clatsop Spit and erosion adjacent to the spit tip have resulted in concerns that part of the southern jetty may eventually be undermined through toe erosion (Hans Moritz, [ USACE], oral commun., [2010]). In addition, because the northern tip of Clatsop Spit is only 380 to $700 \mathrm{~m}$ wide, there are also concerns that this section of the spit could be breached, which would result in the formation of a second river mouth.

During the long term, the average shoreline change rate along the Clatsop Plains subcell was $3.1 \mathrm{~m} / \mathrm{yr}$ (fig. 27), by far the highest rate of coastal change in the State of Oregon. The highest statewide long-term progradation rate, $15.5 \mathrm{~m} / \mathrm{yr}$, is in this cell. Of the 554 transects that were analyzed $(28 \mathrm{~km}$ of shoreline), only 10 percent was eroding in the long term (table 7). In the short term, the rates of progradation were slower, $1.9 \mathrm{~m} / \mathrm{yr}$, with 2 percent of the analyzed transects demonstrating erosion (table 8).

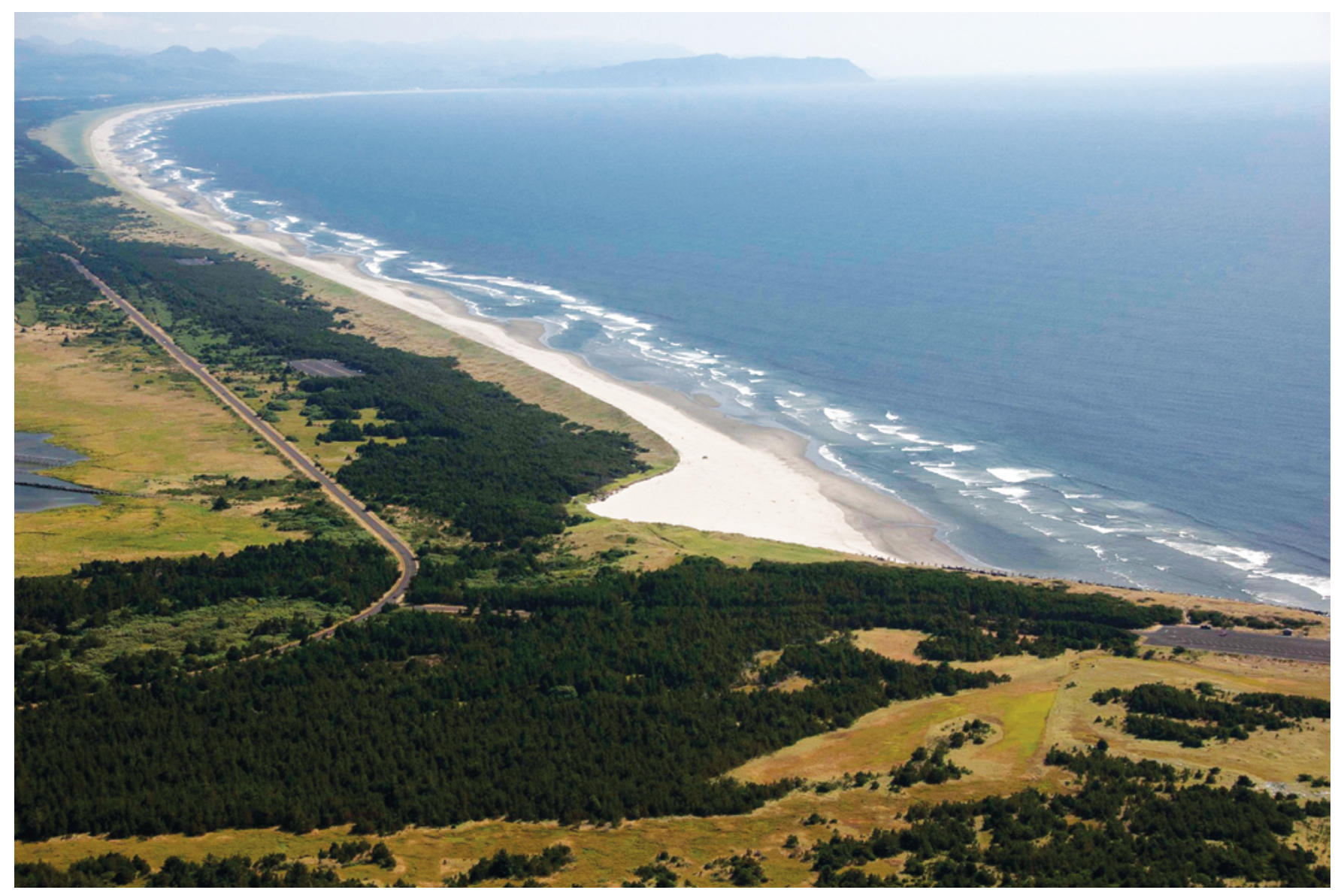

Figure 28. The Clatsop Plains subcell in Oregon looking south toward Tillamook Head, Oregon, in the distance. Photograph by Erica Harris, Oregon Department of Geology and Mineral Industries, 2011. 


\section{Washington}

\section{Columbia River Littoral Cell (Long Beach Subcell)—Columbia River to Willapa Bay}

The Long Beach subcell stretches $44 \mathrm{~km}$ between the north jetty of the Columbia River and Leadbetter Point at the tip of Long Beach Peninsula (figs. 3 and 29). The subcell includes Cape Disappointment State Park, which is a pocket beach between the Columbia River North Jetty and North Head and is one of Washington's most popular State parks. Sediment samples reveal that the median grain size decreases from south to north in this subcell, with the finest sediment located near the entrance to Willapa Bay. Foredune geomorphology is significantly different on either side of the mouth of the Columbia River. The dunes on the Long Beach Peninsula are relatively low in volume and elevation (mean height about $8 \mathrm{~m}$ ), whereas the dunes on the southern side (Clatsop Plains subcell) are much larger. Most of the region's beaches and foredunes eroded during the two intense winters of 1997-8 (a major El Niño event; for example, Kaminsky and others, 1998) and 1998-9 (a moderate La Niña event). Subsequent to these winters, the beaches and foredunes have, for the most part, experienced significant seaward progradation and vertical accretion (fig. 30).

The initial shoreline response due to construction of the Columbia River North Jetty was rapid and was confined to the development of the pocket beach between the jetty and North Head. Not until after 1926 did the shoreline north of North Head show significant changes (Kaminsky and others, 2010). In the long term, the average shoreline change rate in the 41-km Long Beach subcell was $2.6 \mathrm{~m} / \mathrm{yr}$ (table 7), averaged over 810 transects (table 7), with rates ranging from -12.1 to $10.3 \mathrm{~m} / \mathrm{yr}$. Even with the continued erosion in Cape Disappointment State Park, the shoreline progradational trend was higher during the short term than during the longterm with a rate of $4.7 \mathrm{~m} / \mathrm{yr}$ (fig. 27). Short-term change rate variability was even higher than the long term, ranging from -18.7 to $23.2 \mathrm{~m} / \mathrm{yr}$. Only 3 percent of the 741 analyzed transects was eroding in the short term (table 8).

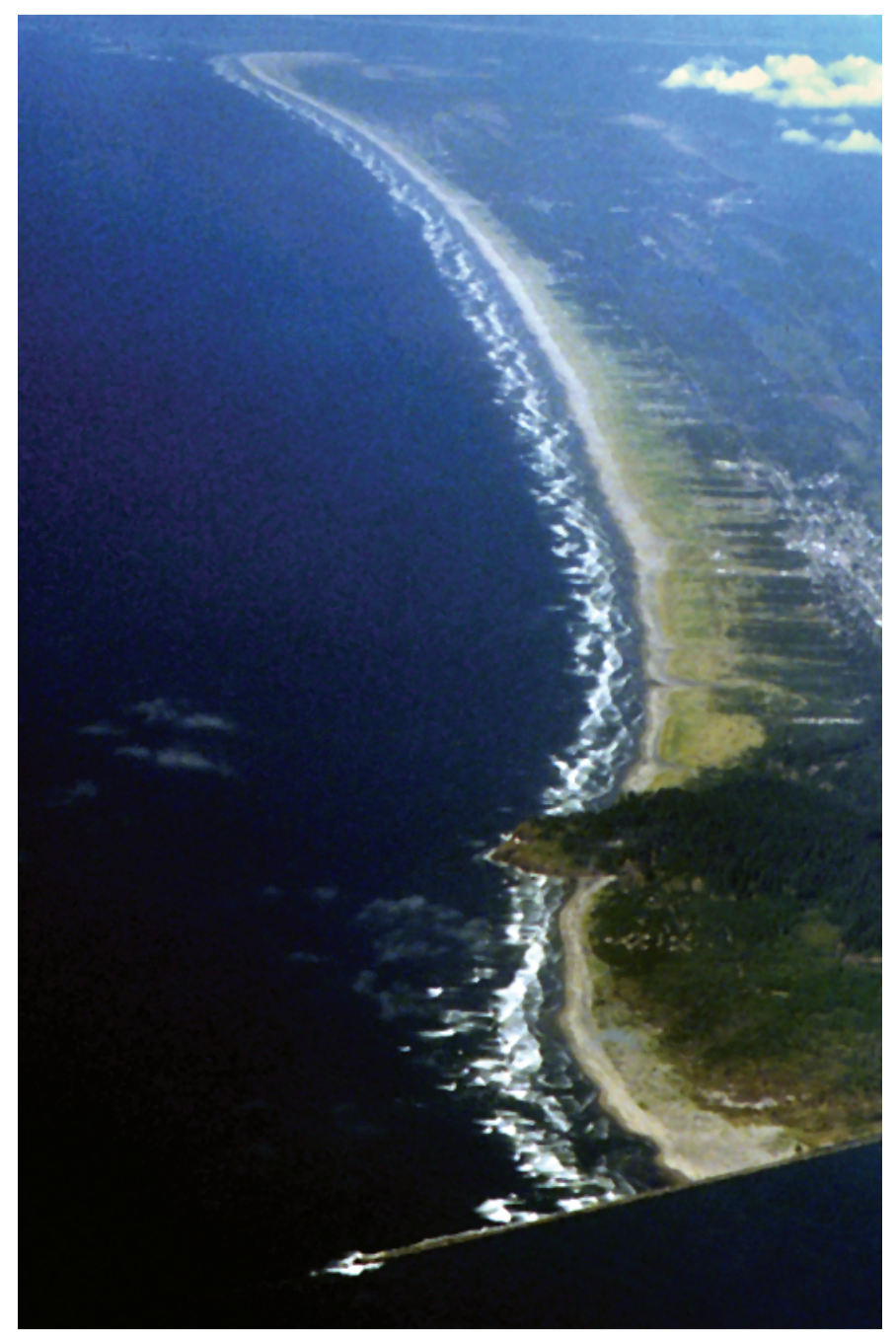

Figure 29. Oblique aerial photograph of the Long Beach subcell in Washington looking north. The Columbia River North Jetty and North Head, Wash., bracket Cape Disappointment State Park at the southern end of the Long Beach Peninsula in Washington. About 40 kilometers to the north is Leadbetter Point, Wash., and the entrance to Willapa Bay, Wash. Photograph by Tor Clausen and Melissa Phipps, Torstudios Photography. 

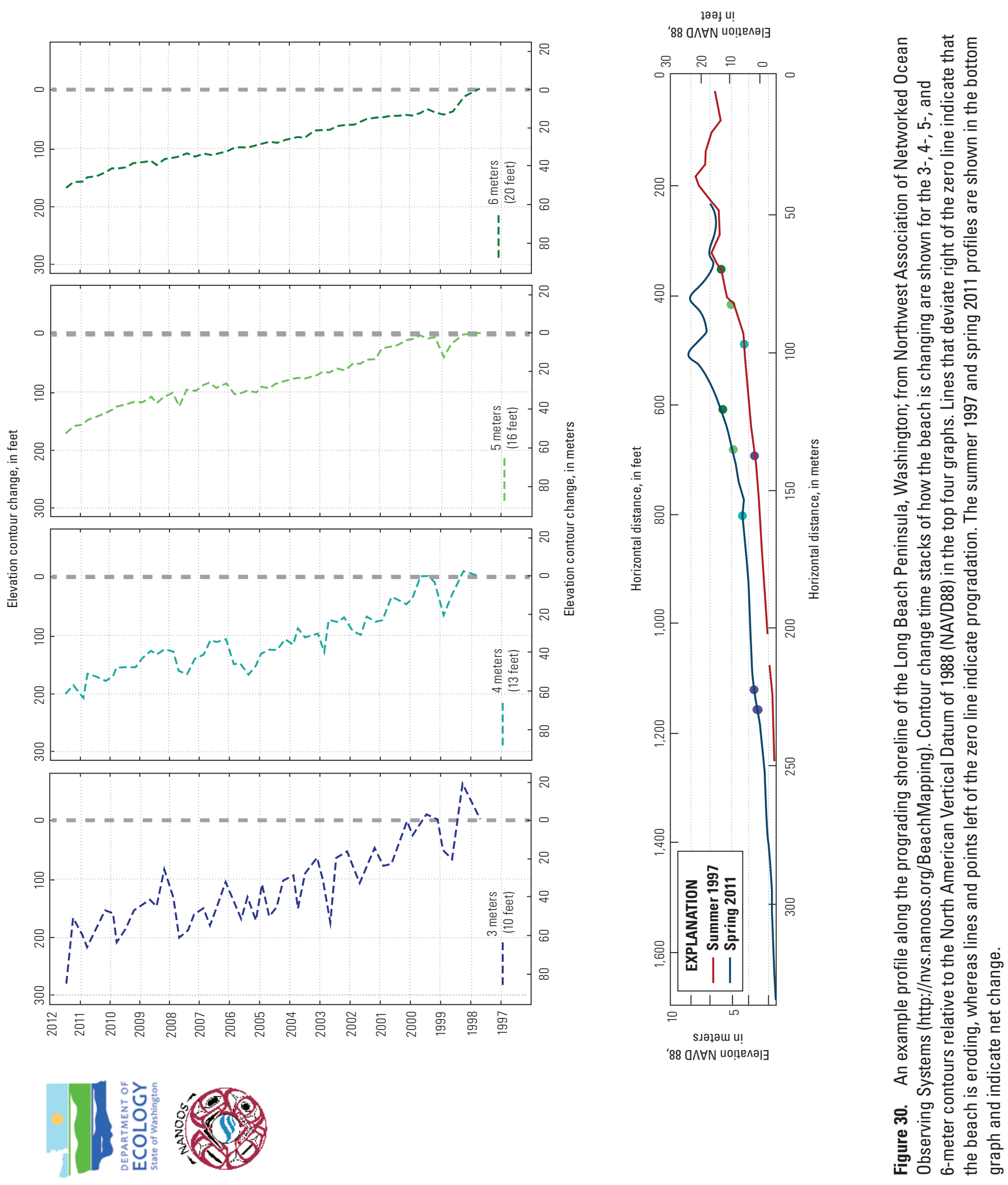


\section{Columbia River Littoral Cell (Grayland Plains Subcell)—Willapa Bay to Grays Harbor}

The Grayland Plains subcell stretches $29 \mathrm{~km}$ between Tokeland and Westport (figs. 3 and 31). Beach slopes are gentle in the center of the subcell and relatively steep in the north and south due to coarse-grained sediment beaches and steep berms, respectively. Since 1852, when the U.S. Coast Survey first mapped Willapa (then Shoalwater) Bay, the shorelines, shoals, and entrance channel positions have substantially changed (Kaminsky and others, 2010). Between 1852 and 1871, Cape Shoalwater grew significantly toward the center, largely emerging from shallow shoals that existed in 1852. However, between 1871 and 1891, erosion along Cape Shoalwater began, and the cape today remains one of the fastest retreating shorelines in the continental United States.

The long-term shoreline change rates, computed during more than 100 years, include erosion of almost $30 \mathrm{~m} / \mathrm{yr}$ in parts of this subcell (fig. 27). The subcell-averaged shoreline change rate, averaged over 428 transects (about $21 \mathrm{~km}$ of shoreline), is $-1.9 \mathrm{~m} / \mathrm{yr}$ during this period. This is the largest cell-averaged erosion rate in the entire PNW during either analysis period, likely because the highest erosion rates for an individual transect during both time periods throughout the PNW occur here (table 7). Only 30 percent of the cell was eroding during this period, whereas much of the remainder of the Grayland subcell prograded during the long term (fig. 27). Variability during the long term was large, with shoreline change rates ranging between -28.6 and $6.6 \mathrm{~m} / \mathrm{yr}$. Sixteen percent of the analyzed transects was eroding at rates faster than $-3 \mathrm{~m} / \mathrm{yr}$ (table 7 ). In the short term, erosion at Cape Shoalwater was high as was progradation to the north; shoreline change rates ranged from -56.5 to $43.1 \mathrm{~m} / \mathrm{yr}$, both values being the highest values in the PNW for this period. On average, the Grayland Plains subcell prograded during the short term at a rate of $1.7 \mathrm{~m} / \mathrm{yr}$. Thirty percent of the cell was eroding during this period, with 23 percent eroding faster than $-3 \mathrm{~m} / \mathrm{yr}$ (table 8 ). In contrast to the long term, some of this erosion in the short term took place along the northern stretches of the cell near the community of Westport (figs. 27 and 32).

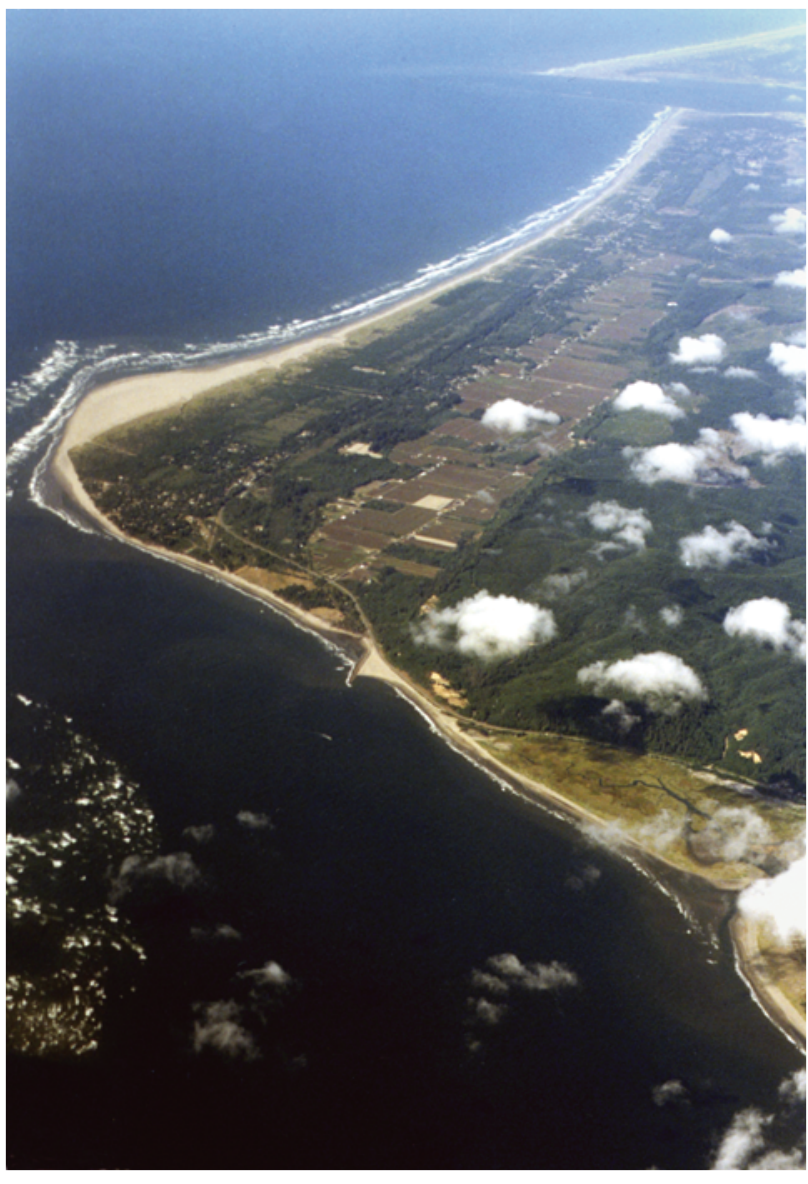

Figure 31. Oblique aerial photograph of the Grayland Plains subcell in Washington looking northwest. The groin and beachfill associated with the State Route 105 Emergency Stabilization Project are shown in the photograph that was taken in June 1999. The bulge of sediment along the middle of the left edge of the photograph is associated with the attachment point of the Willapa Bay ebb-tidal delta in Washington. The feature has been rapidly migrating to the north in the last several years. The entrance to Grays Harbor, Wash., is at the top of the photograph. Note the significant offset between the Grayland Plains subcell shoreline and the North Beach subcell shoreline to the north of Grays Harbor. Photograph by Tor Clausen and Melissa Phipps, Torstudios Photography. 

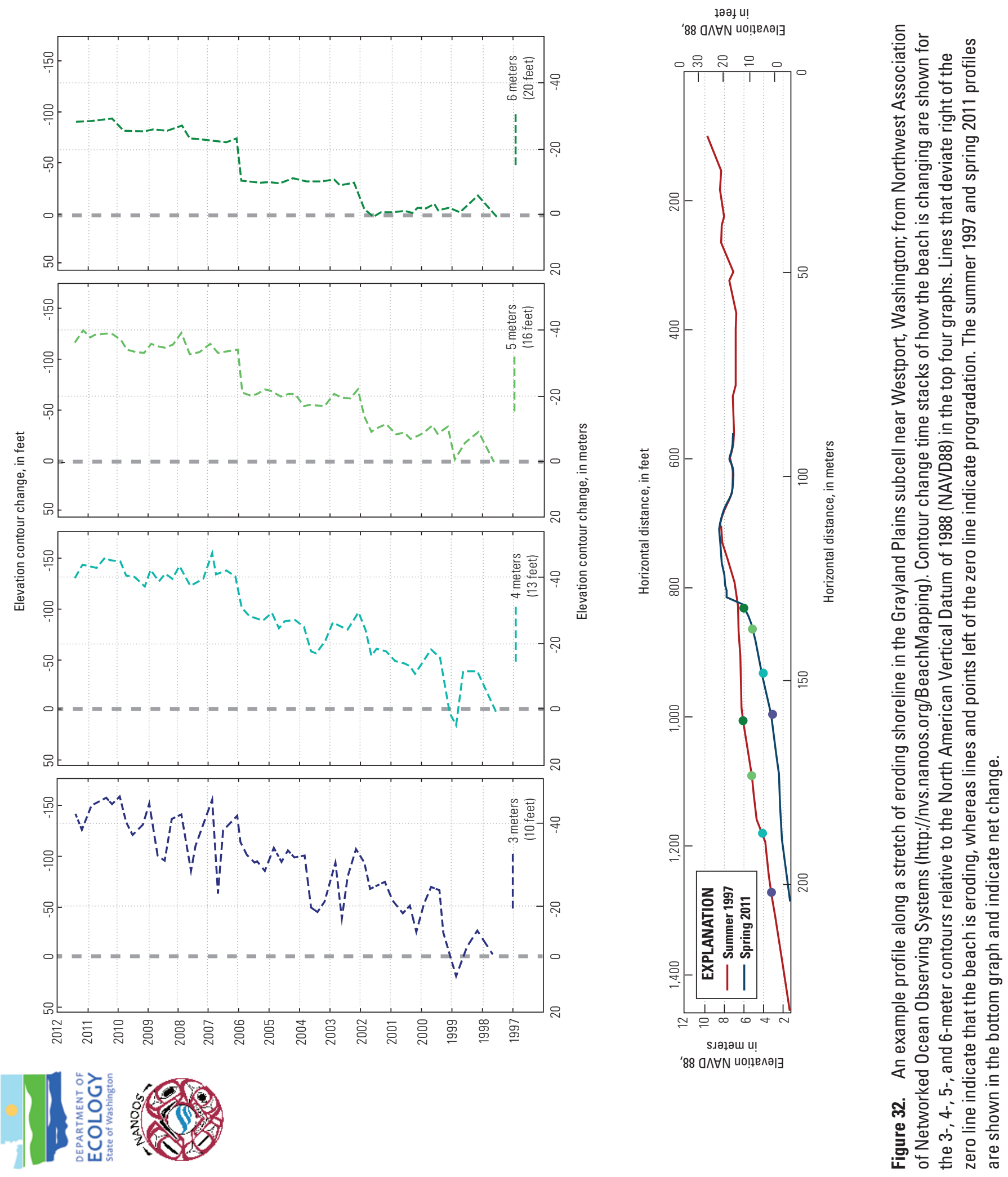


\section{Columbia River Littoral Cell (North Beach Subcell)—Grays Harbor to Point Grenville}

The North Beach subcell spans about $50 \mathrm{~km}$ between the Grays Harbor North Jetty and Point Grenville (figs. 3 and 33). A small cobble beach at the tip of Point Grenville has the steepest average beach slope in the CRLC (Ruggiero and others, 2005). Otherwise, beach slopes in the subcell are

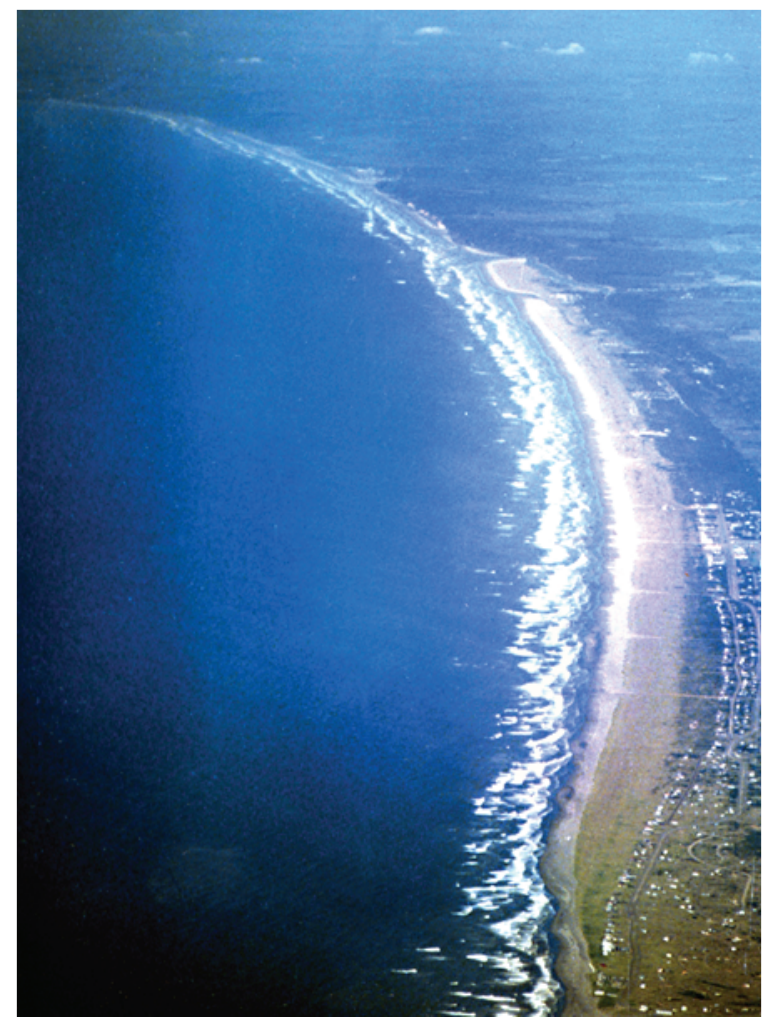

Figure 33. Oblique aerial photograph of the North Beach subcell in Washington looking north. The northern jetty in Grays Harbor and Ocean Shores, Wash., are at the southern end of the North Beach subcell. Photograph by Tor Clausen and Melissa Phipps, Torstudios Photography. steepest at the southern profiles and decrease to the north. Median grain sizes are largest near the mouth of Grays Harbor and decrease to the north where the finest sediment, with a median grain size of about 0.12 millimeter, in the CRLC can be found. Dune crest elevations are highest at the southern end of the subcell and decrease in height to the north. North of the Copalis River, the beaches are backed by cliffs or bluffs.

In the long term, the average shoreline change rates, $4.4 \mathrm{~m} / \mathrm{yr}$, for the North Beach subcell were the most progradational of any littoral cell within the PNW with a maximum rate of $21.8 \mathrm{~m} / \mathrm{yr}$ (table 7). Only 1 percent of the 793 transects analyzed (40 km of shoreline) was eroding during this period (table 7). Rates are high in the short term as well, with a subcell-averaged rate of $4.2 \mathrm{~m} / \mathrm{yr}$, and only 3 percent of analyzed transects eroding (table 8). In the long and short term, there is a clear break in shoreline change trend at the Copalis River, with higher rates of shoreline progradation to the south of the river (fig. 27) than in the north.

\section{Olympic Peninsula—Point Grenville to La Push}

The Olympic Peninsula analysis region extends about $75 \mathrm{~km}$ between Point Grenville and La Push, Washington (fig. 34). Four significant rivers - the Quinault, Queets, Hoh, and Quillayute - enter the Pacific Ocean in this analysis region. There is reduced shoreline coverage in this analysis region in the 1800s and 1950s. Therefore, we computed an additional short-term end-point shoreline change rate between the shoreline position in the 1920s and 1930s and the 2002 lidar-derived shoreline in order to report more complete data for this region (fig. 34). In the long term, 125 transects were analyzed and showed an average change rate of $-0.4 \mathrm{~m} / \mathrm{yr}$ (table 7). Most of this erosion occurred between Point Grenville and Cape Elizabeth, in the southern part of the region (fig. 34). In the short term, the region-averaged shoreline change rate, containing 1,273 transects (64 km of shoreline), was not statistically different than zero. However, almost half of the analyzed transects were eroding during this time period (table 8). 


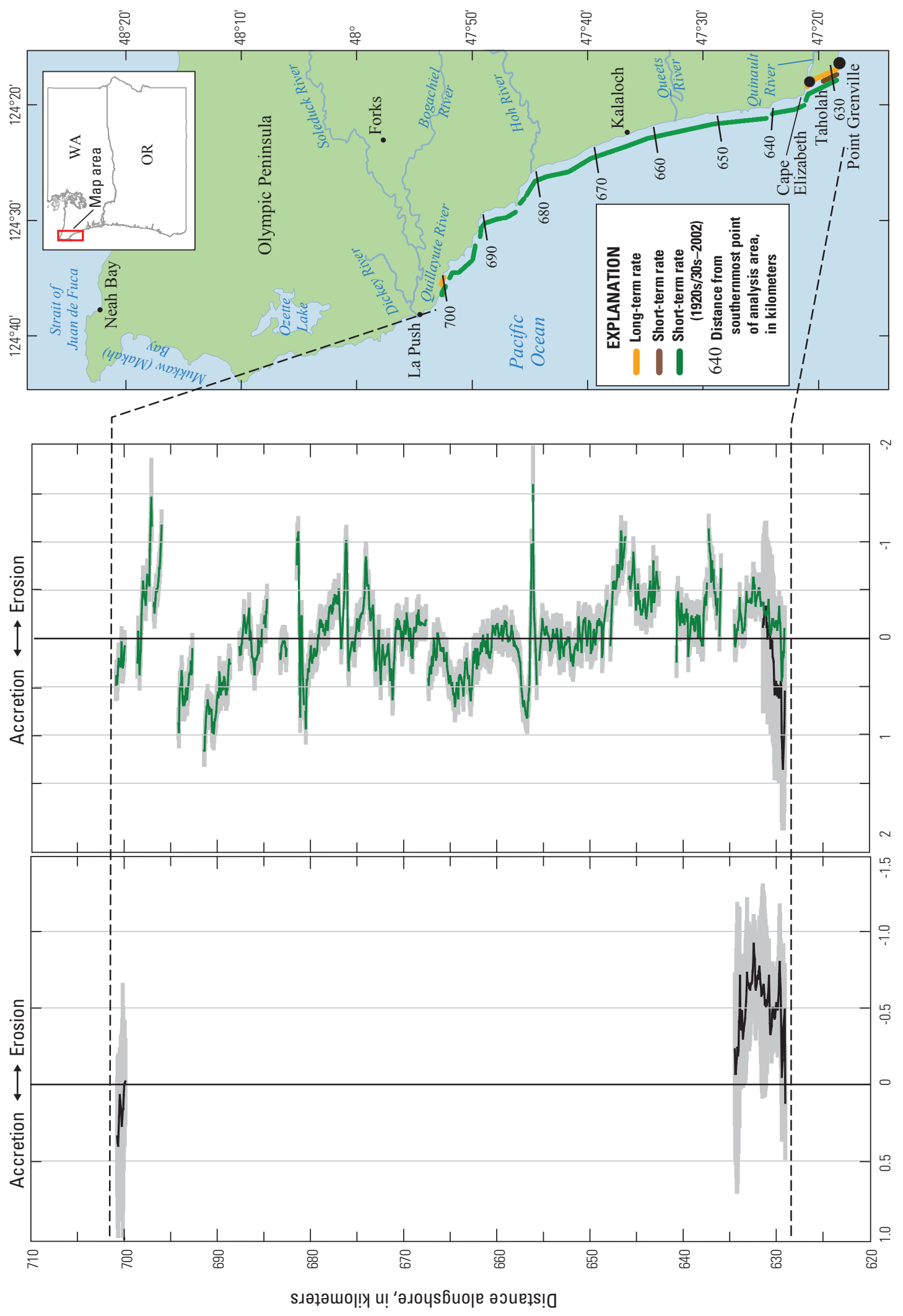

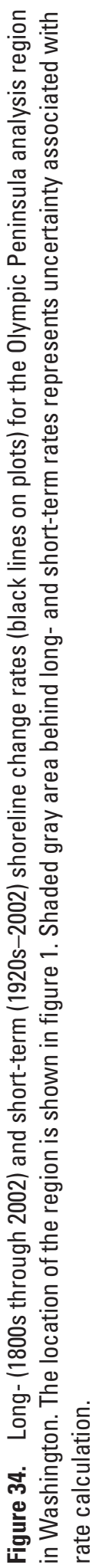




\section{Discussion and Additional Considerations}

\section{Summary of Shoreline Changes}

The total length of coastline in the eight analysis regions in the PNW is about $700 \mathrm{~km}$. Due to data gaps or areas lacking sandy shorelines (that is, rocky coast sections), the shoreline change analysis presented in this report covers about 65 percent of the outer coasts of Oregon and Washington. Where long-term rates were quantified, the regional average rate of shoreline change was $0.9 \mathrm{~m} / \mathrm{yr}$ of progradation with an uncertainty of $0.07 \mathrm{~m} / \mathrm{yr}$. This rate is based on 8,823 individual transects, of which 36 percent was determined to be eroding. The average rate of short-term shoreline change in the PNW was also progradational at the same rate of $0.9 \mathrm{~m} / \mathrm{yr}$, but with an uncertainty of $0.03 \mathrm{~m} / \mathrm{yr}$. This rate is based on 9,087 individual transects of which 44 percent were determined to be eroding. These regional trends of progradation, however, are heavily influenced by the large historical rates of change in the CRLC. More informative than the regional averages are the trends and variability within individual littoral cells, the appropriate scale for considering sediment dynamics and budgets, 22 of which have been analyzed in this report.

Shoreline change analysis in the PNW indicates that there have been significantly different historical shoreline change trends between the CRLC and the other Oregon and northern Washington beaches that have not been influenced by the Columbia River as a source of sediment in the historical period. It has been well documented that CRLC beaches are still evolving from anthropogenic perturbations to the natural system, some of which occurred more than a century ago (Kaminsky and others, 2010). The construction of jetties at both the mouth of the Columbia River and at Grays Harbor has severely altered the natural sediment supply to the CRLC. The majority of the beaches in the CRLC have responded to these human effects through dramatic beach progradation during the past century with rates significantly higher than inferred prehistoric rates. Although the CRLC is still responding to these human effects, in several locations, beaches that had been rapidly prograding are now either prograding at a slower rate or eroding. The development of the extensive flow control systems of the Columbia River (dams and irrigation) may also be affecting the shoreline change rates of the CRLC, but their effect, at least during the time periods studied here, are most likely subsumed within the effects of the jetties (Sherwood and others, 1990; Gelfenbaum and others, 1999; Kaminsky and others, 2010).

There are distinct differences between southern Oregon, the northern Oregon coast, and along the coast of Washington in terms of the degrees and magnitudes of erosion versus progradation. Although the Columbia River certainly delivered sediments to other PNW beaches when sea level was lower than it is today, it is evident from beach sand compositions that, at present, the Columbia River only provides sediment to the CRLC. Other PNW beaches, particularly those within the many individual littoral cells that make up the rest of the Oregon coast and Washington's Olympic Peninsula, have relatively limited sand sources. In the long term, only three of Oregon's 17 non-CRLC littoral cells had statistically significant trends of erosion. However, in the short term, 10 of these littoral cells were eroding.

An increase in the erosion hazard along much of Oregon may be related to the effects of sea-level rise and increasing storm wave heights (Ruggiero, 2013). Of importance, particularly in the short term, is the alongshore variability in land uplift rates due to tectonics, which result in alongshore varying rates and directions of relative sea-level rise; this variability in uplift appears to at least partially control the regional variability in short-term shoreline change rates. Other climate related processes, such as the occurrence of major El Niños, also effect the shoreline changes in the region. Major El Niños elevate monthly mean sea levels by tens of centimeters throughout the winter and produce a shift in the storm tracks that results in alongshore redistributions in sand volumes on the beaches and hotspot erosion. There are limited modern-day sources of sand to many Oregon beaches, with much of the sand being relict. Many beaches today are deficient in sand volumes and therefore do not provide sufficient buffer protection to backshore properties during winter storms.

\section{Influence of Human Activities}

Unlike many other coastlines in the United States, the population of the PNW is relatively small; however, human activities still affect the shorelines of the region. The construction of jetties at river mouths to aid navigation has resulted in the most significant effects. The Bandon jetties constructed in the late 1800s at the mouth of the Coquille River (fig. 35) resulted in significant changes to the shoreline and can be considered a classic case of the effect of jetty construction on shorelines throughout much of Oregon. This type of response demonstrates the existence of a seasonally reversing longshore sediment transport which trends northward during the winter and southward in the summer, but with the long-term net transport being effectively zero (Komar and others, 1976). In the CRLC, jetties also affect seasonally reversing longshore sediment transport patterns; however, the primary driver of jetty-induced shoreline change has been the onshore transport and welding to the shoreline of the flanks of the ebb-tidal deltas (Kaminsky and others, 2010).

Sediment transport pathways, particularly at the mouth of the Columbia River, have been mechanically enhanced through channel dredging and offshore disposal. In recent decades, offshore disposal of dredged sand from the Columbia River entrance has possibly reduced the littoral sediment budget and contributed to erosion of the inner delta and 


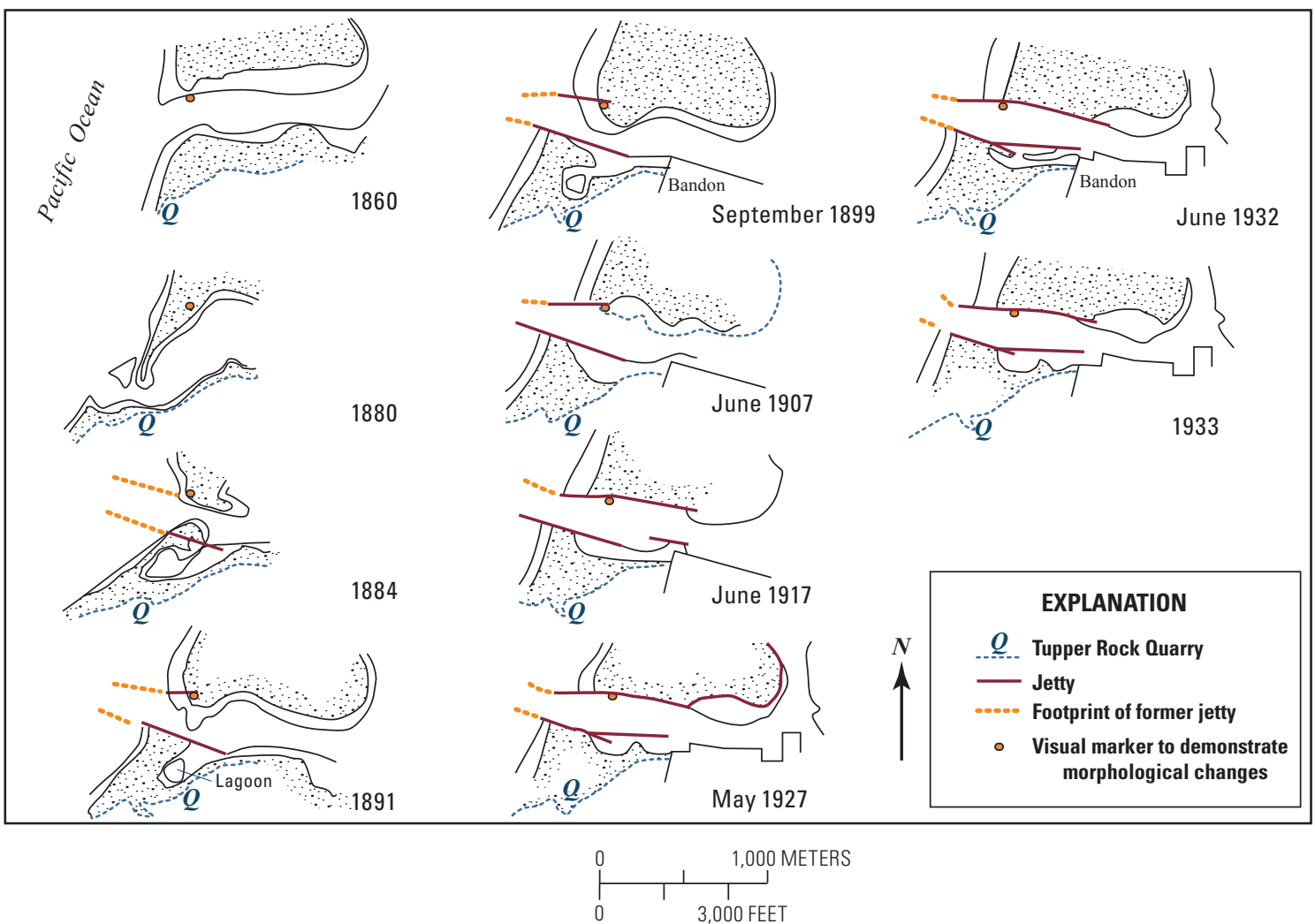

Figure 35. Survey line drawings prepared by the U.S. Army Corps of Engineers before and during construction of the Coquille River jetties adjacent to Bandon, Oregon; modified from Komar and others (1991).

adjacent coasts. Additionally, dams and irrigation have reduced river flows and sand supply from the Columbia River - the primary source of CRLC sediment — during the historical period. From the time significant flow regulation began in 1969 (Sherwood and others, 1990) through 2008, the USACE has disposed $53.5 \mathrm{Mm}^{3}$ of dredged sand outside the littoral zone (U.S. Army Corps of Engineers, 2009). This amount is nearly equivalent to the estimated supply of fluvial sediment to the estuary during this period (Gelfenbaum and others, 1999). The probability of significant sand export has likely decreased with the reduction in the magnitude and frequency of peak floods (Lockett, 1963). At present, the balance between sand imported to and exported from the estuary remains unclear.

Distinguishing between natural rates of shoreline movement and those influenced directly by human activities is crucial when historical rates of change are used for planning or management purposes and to forecast future shoreline positions. Improving methods of analyzing shoreline movement will help to accurately document the natural rates of shoreline change.

\section{References Cited}

Allan, J.C., and Hart, Roger, 2008, Oregon beach and shoreline mapping and analysis program-2007-2008 beach monitoring report: Portland, Oreg., Oregon Department of Land Conservation and Development Open File Report O-08-15, 60 p.

Allan, J.C., and Komar, P.D., 2000, Are ocean wave heights increasing in the eastern North Pacific?: Eos, Transactions of the American Geophysical Union, v. 81, no. 47, p. 561-567.

Allan, J.C., and Komar, P.D., 2002, Extreme storms on the Pacific Northwest coast during the 1997-98 El Niño and 1998-99 La Niña: Journal of Coastal Research, v. 18, no. 1, p. 175-193.

Allan, J.C., and Komar, P.D., 2004, Environmentally compatible cobble berm and artificial dune for shore protection: Shore and Beach, v. 72, no. 1, p. 9-18. 
Allan, J.C., and Komar, P.D., 2006, Climate controls on U.S. west coast erosion processes: Journal of Coastal Research, v. 22, no. 3, p. 511-529.

Allan, J.C., and Priest, G.R., 2001, Evaluation of coastal erosion hazard zones along dune and bluff backed shorelines in Tillamook County, Oregon-Cascade Head to Cape Falcon: Portland, Oreg., Oregon Department of Geology and Mineral Industries Open File Report O-01-03, $126 \mathrm{p}$.

Allan, J.C., and Stimely, Laura, in press, Oregon beach shoreline mapping and analysis program-Quantifying short to long-term beach and shoreline changes in the Gold Beach, Nesika, and Netarts littoral cells: Portland, Oreg., Oregon Department of Geology and Mineral Industries.

Allan, J.C., Komar, P.D., and Priest, G.R., 2003, Shoreline variability on the high-energy Oregon coast and its usefulness in erosion-hazard assessments: Journal of Coastal Research, special issue 38, fall, p. 83-105.

Allan, J.C., Komar, P.D., Ruggiero, Peter, and Witter, Robert, 2012, The March 2011 Tōhoku tsunami and its impacts along the U.S. west coast: Journal of Coastal Research, v. 28, no. 5, p. 1142-1153.

Allan, J.C., Witter, R.C., Ruggiero, Peter, and Hawkes, A.D., 2009, Coastal geomorphology, hazards, and management issues along the Pacific northwest coast of Oregon and Washington, in O'Connor, J.E., Dorsey, R.J., and Madin, I.P., eds., Volcanoes to vineyards - Geologic field trips through the dynamic landscape of the Pacific northwest: Geological Society of America Field Guide 15, p. 495-519.

Anders, F.J., and Byrnes, M.R., 1991, Accuracy of shorelines change rates as determined from maps and aerial photographs: Shore and Beach, v. 59, no. 1, p. 17-26.

Atwater, B.F., 1987, Evidence for great Holocene earthquakes along the outer coast of Washington state: Science, v. 236, no. 4804, p. 942-944.

Atwater, B.F., and Hemphill-Haley, Eileen, 1997, Recurrence intervals for great earthquakes of the past 3,500 years at northeastern Willapa Bay, Washington: U.S. Geological Survey Professional Paper 1576, 108 p.

Barnard, P.L., Allan, Jonathan, Hansen, J.E., Kaminsky, G.M., Ruggiero, Peter, and Doria, André, 2011, The impact of the 2009-10 El Niño modoki on U.S. west coast beaches: Geophysical Research Letters, v. 38, no. 13, 7 p.

Boyd, R.T., 1990, Demographic history, 1774-1874, in Suttles, Wayne, and Sturtevant, William, eds., Northwest coast: Washington, D.C., Smithsonian Institution Press Handbook of North American Indians, v. 7, p. 135-148.

Buijsman, M.C., Kaminsky, G.M., and Gelfenbaum, Guy, 2003a, Shoreline change associated with jetty construction, deterioration, and rehabilitation at Grays Harbor, Washington: Shore and Beach, v. 71, p. 15-22.
Buijsman, M.C., Sherwood, C.R., Gibbs, A.E., Gelfenbaum, Guy, Kaminsky, George, Ruggiero, Peter, Franklin, Jerry, 2003b, Regional sediment budget of the Columbia River littoral cell, USA - Analysis of bathymetric- and topographic-volume change: U.S. Geological Survey Open File Report 02-281, 140 p. plus 5 appendixes.

Burgette, R.J., Weldon, R.J., II, and Schmidt, D.A., 2009, Interseismic uplift rates for western Oregon and alongstrike variation in locking on the Cascadia subduction zone: Journal of Geophysical Research: Solid Earth, v. 114, no. B1, 24 p.

Clemens, K.E., and Komar, P.D., 1988, Oregon beach-sand compositions produced by the mixing of sediments under a transgressing sea: Journal of Sedimentary Petrology, v. 58, no. 3, p. 519-529.

Cooper, W.S., 1958, Coastal sand dunes of Oregon and Washington: Geological Society of America Memoir 72, $169 \mathrm{p}$.

Crowell, Mark, and Leatherman, S.P., 1999, Coastal erosion mapping and management: Journal of Coastal Research, special issue $28,196 \mathrm{p}$.

Crowell, Mark, Leatherman, S.P., and Buckley, M.K., 1991, Historical shoreline change-Error analysis and mapping accuracy: Journal of Coastal Research, v. 7 no. 3, p. 839-852.

Dolan, Robert, Anders, Fred, and Kimball, Suzette, 1985, Coastal Erosion and Accretion: National Atlas of the United States of America: U.S. Geological Survey, Reston, Virginia, 1 map sheet. OCLC Number 81459810.

Douglas, B.C., and Crowell, Mark, 2000, Long-term shoreline position prediction and error propagation: Journal of Coastal Research, v. 16, no. 1, p. 145-152.

Favre, Alice, and Gershunov, Alexander, 2006, Extra-tropical cyclonic/anticyclonic activity in north-eastern Pacific and air temperature extremes in western North America: Climate Dynamics, v. 26, p. 617-629.

Fenster, M.S., Dolan, Robert, and Elder, J.F., 1993, A new method for predicting shoreline positions from historical data: Journal of Coastal Research, v. 9, no. 1, p. 147-171.

Fenster, Michael, and Dolan, Robert, 1994, Large-scale reversals in shoreline trends along the U.S. mid-Atlantic coast: Geology, v. 22, no. 6, p. 543-546.

Fletcher, C.H., Romine, B.M., Genz, A.S., Barbee, M.M., Dyer, Matthew, Anderson, T.R., Lim, S.C., Vitousek, Sean, Bochicchio, Christopher, and Richmond, B.M., 2012, National assessment of shoreline change-Historical shoreline changes in the Hawaiian Islands: U.S. Geological Survey Open-File Report 2011-1051, 55 p.

Garrett, C.J.R., and Toulany, Bechara, 1981, Variability of the flow through the strait of Belle Isle: Journal of Marine Research, v. 39, no. 1, p. 163-189. 
Gelfenbaum, Guy, and Kaminsky, G.M., 2010, Large-scale coastal change in the Columbia River littoral cell-An overview: Marine Geology, v. 273, nos. 1-4, p. 1-10.

Gelfenbaum, Guy, Buijsman, M.C., Sherwood, C.R., Moritz, H.R., and Gibbs, A.E., 2001, Coastal evolution and sediment budget at the mouth of the Columbia River, USA, in Manson, Hans, and Larson, Magnus, eds., Coastal Dynamics 2001-4th International Conference on Coastal Dynamics, Lund, Sweden, June 11-15, 2001, Proceedings: Reston, Va., American Society of Civil Engineers, p. $818-827$.

Gelfenbaum, Guy, Sherwood, C.R., Peterson, C.D., Kaminsky, G.M., Buijsman, Maarten, Twichell, D.C., Ruggiero, Peter, Gibbs, A.E., and Reed, Christopher, 1999, The Columbia River littoral cell-A sediment budget overview, in Kraus, N.C., and McDougal, W.G., eds., Coastal Sediments '99- Proceedings of the Fourth International Symposium on Coastal Engineering and Science of Coastal Sediment Processes, Hauppauge, N.Y., June 21-23, 1999: Reston, Va., American Society of Civil Engineers, p. 1660-1675.

Gemmrich, Johannes, Thomas, Bridget, and Bouchard, Richard, 2011, Observational changes and trends in northeast Pacific wave records: Geophysical Research Letters, v. 38, no. 22, L22601, 5 p.

Geng, Quanzhen, and Sugi, Masato, 2003, Possible change of extratropical cyclone activity due to enhanced greenhouse gases and sulfate aerosols - Study with a high-resolution AGCM: Journal of Climate, v. 16, p. 2262-2274.

Gibbs, A.E., and Gelfenbaum, Guy, 1999, Bathymetric change off the Washington-Oregon coast, in Kraus, N.C., and McDougal, W.G., eds., Coastal Sediments '99Proceedings of the Fourth International Symposium on Coastal Engineering and Science of Coastal Sediment Processes, Hauppauge, N.Y., June 21-23, 1999: Reston, Va., American Society of Civil Engineers, p. 1627-1642.

Goldfinger, Chris, Nelson, C.H., Morey, A.E., Johnson, J.E., Patton, J.T., Karabanov, Eugene, Gutiérrez-Pastor, Julia, Eriksson, A.T., Gràcia, Eulàlia, Dunhill, Gita, Enkin, R.J., Dallimore, Audrey, and Vallier, Tracy, 2012, Turbidite event history-Methods and implications for Holocene paleoseismicity of the Cascadia subduction zone: U.S. Geological Survey Professional Paper 1661-F, 170 p.

Graham, N.E., and Diaz, H.F., 2001, Evidence for intensification of north Pacific winter cyclones since 1948: Bulletin of American Meteorological Society, v. 82, no. 9, p. 1869-1893.

H. John Heinz III Center for Science, Economics, and the Environment, The, 2000, Evaluation of erosion hazards: Federal Emergency Management Agency, 203 p.
Hacker, S.D., Zarnetske, Phoebe, Seabloom, Eric, Ruggiero, Peter, Mull, Jeremy, Gerrity, Shawn, and Jones, Colin, 2012, Subtle differences in two non-native congeneric beach grasses significantly affect their colonization, spread, and impact: Oikos, v. 121, no. 1, p. 138-148.

Hapke, C.J., Adams, P.N., Allan, Jonathan, Ashton, Andrew, Griggs, G.B., Hampton, M.A., Kelly, Joseph, and Young, A.P., in press, The USA, in Kennedy, D.A., Stevenson, W.J., and Naylor, L.A., eds., Rocky coast geomorphology-A global synthesis: Geological Society of London Memoir.

Hapke, C.J., and Reid, David, 2007, National assessment of shoreline change, part 4-Historical coastal cliff retreat along the California coast: U.S. Geological Survey OpenFile Report 2007-1133, 51 p.

Hapke, C.J., Himmelstoss, E.A., Kratzmann, M.G., List, J.H., and Thieler, E.R., 2011, National assessment of shoreline change-Historical shoreline change along the New England and mid-Atlantic coasts: U.S. Geological Survey Open-File Report 2010-1118, 57 p.

Hapke, C.J., Reid, David, Richmond, B.M., Ruggiero, Peter, and List, Jeff, 2006, National assessment of shoreline change-Part 3-Historical shoreline change and associated coastal land loss along the sandy shorelines of the California coast: U. S. Geological Survey Open-File Report 2006-1219, $72 \mathrm{p}$.

Himmelstoss, E.A., 2009, DSAS 4.0-Installation instructions and user guide, in Thieler, E.R., Himmelstoss, E.A., Zichichi, J.L., and Ergul, Ayhan, Digital shoreline analysis system (DSAS) version 4.0-An ArcGIS extension for calculating shoreline change: U.S. Geological Survey Open-File Report 2008-1278, 79 p. [Version 4.2 available at http://woodshole.er.usgs.gov/project-pages/dsas/version4/ images/pdf/DSASv4_2.pdf.]

Inman, D.L., and Nordstrom, C.E., 1971, On the tectonic and morphologic classification of coasts: Journal of Geology, v. 79 , no. 1 , p. 1-21.

Jennings, Richard, and Shulmeister, James, 2002, A field based classification scheme for gravel beaches: Marine Geology, v. 186, nos. 3-4, p. 211-228.

Kaminsky, G.K., Ruggiero, Peter, Buijsman, M.C., McCandless, Diana, and Gelfenbaum, Guy, 2010, Historical evolution of the Columbia River littoral cell: Marine Geology, v. 273, no. 1, p. 96-126.

Kaminsky, G.M., Buijsman, M.C., and Ruggiero, Peter, 2001, Predicting shoreline change at decadal scale in the Pacific Northwest, USA, in Edge, B.L, ed., Coastal Engineering 2000-Proceedings of the 27th International Conference on Coastal Engineering, Sydney, Australia, July 16-21, 2000: Reston, Va., American Society of Civil Engineers, p. 2400-2413. 
Kaminsky, G.M., Buijsman, M.C., Gelfenbaum, Guy, Ruggiero, Peter, Jol, H.M., Gibbs, A.E., and Peterson, C.D., 1999a, Synthesizing geological observations and processes - Response data for modeling coastal change at management scale, in Kraus, N.C., and McDougal, W.G., eds., Coastal Sediments '99-Proceedings of the Fourth International Symposium on Coastal Engineering and Science of Coastal Sediment Processes, Hauppauge, June 21-23, 1999: Reston, Va., American Society of Civil Engineers, p. 1660-1675.

Kaminsky, G.M., Daniels, R.C., Huxford, Robert, McCandless, Diana, and Ruggiero, Peter, 1999b, Mapping erosion hazard areas in Pacific County, Washington: Journal of Coastal Research, special issue 28, p. 158-170.

Kaminsky, G.M., Ruggiero, Peter, and Gelfenbaum, Guy, 1998, Monitoring coastal change in southwest Washington and northwest Oregon during the 1997/98 El Niño: Shore and Beach, v. 66 , no. 3, p. 42-51.

Kelsey, H.M., Nelson, A.R., Hemphill-Haley, Eileen, and Witter, R.C., 2005, Tsunami history of an Oregon coastal lake reveals a 4,600 yr record of great earthquakes on the Cascadia subduction zone: Geological Society of America Bulletin, v. 117, nos. 7-8, p. 1009-1032.

Komar, P.D., 1986, The 1982-83 El Niño and erosion on the coast of Oregon: Shore and Beach, v. 54, no. 2, p. 3-12.

Komar, P.D., 1997, The Pacific Northwest coast—Living with the shores of Oregon and Washington: Durham, N.C., Duke University Press, $195 \mathrm{p}$.

Komar, P.D., 1998, The 1997-98 El Niño and erosion of the Oregon coast: Shore and Beach, v. 66, no. 3, p. 33-41.

Komar, P.D., Allan, J.C., and Ruggiero, Peter, 2009, Ocean wave climates-Trends and variations due to Earth's changing climate, in Kim, Y.C., ed., Handbook of coastal and ocean engineering: Singapore, World Scientific Publishing Co., p. 971-975.

Komar, P.D., Allan, J.C., and Ruggiero, Peter, 2011, Sea level variations along the U.S. Pacific Northwest coast-Tectonic and climate controls: Journal of Coastal Research, v. 27, no. 5, p. 808-823.

Komar, P.D., Allan, J.C., and Ruggiero, Peter, 2013, U.S. Pacific Northwest coastal hazards-Tectonic and climate controls, chap. 21 of Finkl, C.W., ed., Coastal hazards: Springer Coastal Research Library, v. 1000, p. 587-674.

Komar, P.D., Allan, J.C., Dias-Méndez, G.M., Marra, J.J., and Ruggiero, Peter, 2000, El Niño and La NiñaErosion processes and impacts, in Edge, B.L, ed., Coastal Engineering 2000-Proceedings of the 27th International Conference on Coastal Engineering, Sydney, Australia, July 16-21, 2000: Reston, Va., American Society of Civil Engineers, p. 2414-2427.

Komar, P.D., and Rea, C.C., 1976, Erosion of Siletz spit, Oregon: Shore and Beach, v. 44, p. 9-15.
Komar, P.D., and Shih, S.M, 1993, Cliff erosion along the Oregon coast-A tectonic-sea level imprint plus local controls by beach processes: Journal of Coastal Research, v. 9 , no. 3, p. 747-765.

Komar, P.D., Lizarraga-Arciniega, J.R., and Terich, T.A., 1976, Oregon coast shoreline changes due to jetties: Journal of Waterways, Harbors, and Coastal Engineering, v. 102, no. 1 , WW1, p. 13-30.

Komar, P.D., McDougal, W.G., and Ruggiero, Peter, 1996, Beach erosion at Brookings, Oregon-Causes and mitigation: Shore and Beach, v. 64, no. 2, p. 17-28.

Komar, P.D., Torstenson, R.W., and Shih, S.M., 1991, Bandon, Oregon-Coastal development and the potential for extreme ocean hazards: Shore and Beach, v. 59, p. 14-22.

Krabill, W.B., Wright, C.W., Swift, R.N., Frederick, E.B., Manizade, S.S., Yungel, J.K., Martin, C.F., Sonntag, J.G., Duffy, Mark, Hulslander, William, and Brock, J.C., 2000, Airborne laser mapping of Assateague national seashore beach: Photogrammetric Engineering and Remote Sensing, v. 66 , no. 1 , p. $65-71$.

Kratzmann, Meredith, Himmelstoss, E.A., Ruggiero, Peter, Thieler, E.R., and Reid, David, 2013, The national assessment of shoreline change-A GIS compilation of vector shorelines and associated shoreline change data for the Pacific Northwest coast: U.S. Geological Survey OpenFile Report 2012-1008, accessed December 9, 2013, at http://pubs.usgs.gov/of/2012/1008/.

Lee, Henry, II, and Brown, C.A., eds., 2009, Classification of regional patterns of environmental drivers and benthic habitats in Pacific Northwest estuaries: U.S. Environmental Protection Agency, Office of Research and Development EPA/600/R-09/140, 298 p.

Lockett, J.B., 1963, Phenomena affecting improvement of the lower Columbia estuary and entrance, in Johnson, J.W., ed., Proceedings of the 8th Conference on Coastal Engineering, Mexico City, Mexico, November 1962: Council on Wave and The Engineering Foundation, p. 695-755.

McCabe, G.J., Clark, M.P., and Serreze, M.C., 2001, Trends in northern hemisphere surface cyclone frequency and intensity: Journal of Climate, v. 14, no. 12, p. 2763-2768.

Méndez, F.J., Menéndez, Melissa, Luceño, Alberto, and Losada, I.J., 2006, Estimation of the long-term variability of extreme significant wave height using a time-dependent peak over threshold (POT) model: Journal of Geophysical Research: Oceans, v. 111, issue C7, C07024, 13 p.

Menéndez, Melisa, Méndez, F.J., Losada, I.J., and Graham, N.E., 2008, Variability of extreme wave heights in the northeast Pacific ocean based on buoy measurements: Geophysical Research Letters, v. 35, no. 22, L22607, 6 p.

Moore, L.J., 2000, Shoreline mapping techniques: Journal of Coastal Research, v. 16, no. 1, p. 111-124. 
Moore, L.J., Ruggiero, Peter, and List, J.H., 2006, Comparing mean high water and high water line shorelines-Should proxy-datum offsets be incorporated into shoreline change analysis?: Journal of Coastal Research, v. 22, no. 4, p. 894-905.

Morton, R.A., 1991, Accurate shoreline mapping-Past, present, and future, in Coastal Sediments 1991Proceedings of a Specialty Conference on Quantitative Approaches to Coastal Sediment Processes, Seattle, Wash., June 25-27, 1991: Reston, Va., American Society of Civil Engineers, v. 1, p. 997-1010.

Morton, R.A., 1996, Geoindicators of coastal wetlands and shorelines, in Berger, A.R., and Iams, W.J., eds., Geoindicators-Assessing rapid environmental change in Earth systems: Rotterdam, Netherlands, A.A. Balkema, p. 207-230.

Morton, R.A., and Miller, Tara, 2005, National assessment of shoreline change-Part 2-Historical shoreline changes and associated coastal land loss along the U.S. southeast Atlantic coast: U.S. Geological Survey Open-File Report 2005-1401, 35 p.

Morton, R.A., Miller, T.L, and Moore, L.J., 2004, National assessment of shoreline change-Part 1-Historical shoreline changes and associated coastal land loss along the U.S. Gulf of Mexico: U.S. Geological Survey Open File Report 2004-1043, 44 p.

Mull, J.M., 2011, Coastal sand dunes in the U.S. Pacific Northwest-Regional variability in foredune geomorphology and associated physical vulnerability to hazards: Corvallis, Oreg., Oregon State University master's thesis, $134 \mathrm{p}$. (Also available at http://seagrant.oregonstate. edu/sgpubs/y-10-012.)

Nelson, A.R., Kelsey, H.M., and Witter, R.C., 2006, Great earthquakes of variable magnitude at the Cascadia subduction zone: Quaternary Research, v. 65, p. 354-365

Peterson, C.D., Jackson, P.L., O’Neil, D.J., Rosenfeld, C.L., and Kimerling, A.J., 1990, Littoral cell response to interannual climatic forcing 1983-1987 on the central Oregon coast, USA: Journal of Coastal Research, v. 6, no. 1, p. 87-110.

Peterson, C.D., Jol, H.M., Vanderburgh, Sandy, Phipps, J.B., Percy, David, and Gelfenbaum, Guy, 2010a, Dating of late Holocene beach shoreline positions by regional correlation of coseismic retreat events in the Columbia River littoral cell, USA: Marine Geology, v. 273, nos. 1-4, p. 44-61.

Peterson, C.D., Vanderburgh, Sandy, Roberts, M.C., Jol, H.M., Phipps, J.B., and Twichell, D.C., 2010b, Composition, age, and depositional rates of shoreface deposits under barriers and beach plains of the Columbia River littoral cell, USA: Marine Geology, v. 273, nos. 1-4, p. 62-82.

Phipps, J.B., 1990, Coastal accretion and erosion in southwest Washington, 1977-1987: Olympia, Wash., Washington State Department of Ecology WDOE 90-21, 40 p.
Phipps, J.B., and Smith, J.M., 1978, Pacific ocean beach erosion and accretion report: Olympia, Wash., Washington State Department of Ecology, $75 \mathrm{p}$.

Priest, G.R, Saul, Ingmar, and Diebenow, Julie, 1994, Explanation of chronic geologic hazard maps and erosion rate database, coastal Lincoln County, Oregon-Salmon River to Seal Rocks: Portland, Oreg., Oregon Department of Geology and Mineral Industries Open-File Report 0-94-11, 45 p.

Priest, G.R., 1999, Coastal shoreline change study northern and central Lincoln County, Oregon: Journal of Coastal Research, v. 81, no. 28 , p. 140-157.

Priest, G.R., Allan, J.C., and Sonnevil, R.A., 2004, Evaluation of coastal erosion hazard zones from Sisters Rocks to North Gold Beach, Curry County, Oregon: Portland, Oreg., Oregon Department of Geology and Mineral Industries Open File Report 0-04-20, 174 p.

Revell, D.L., Komar, P.D., and Sallenger, A.H., Jr., 2002, An application of lidar to analyses of El Niño erosion in the Netarts littoral cell, Oregon: Journal of Coastal Research, v. 18 , no. 4 , p. $792-801$.

Ruggiero, Peter, 2013, Is the intensifying wave climate of the U.S. Pacific Northwest increasing flooding and erosion risk faster than sea level rise?: Journal of Waterway, Port, Coastal, and Ocean Engineering, v. 139, no. 2, p. 88-97.

Ruggiero, Peter, and List, J.H., 2009, Improving accuracy and statistical reliability of shoreline position and change rate estimates: Journal of Coastal Research, v. 25, no. 5, p. 1069-1081.

Ruggiero, Peter, Kaminsky, G.M., and Gelfenbaum, Guy, 2003, Linking proxy-based and datum-based shorelines on highenergy coastlines-Implications for shoreline change analyses: Journal of Coastal Research, special issue 38, p. 57-82.

Ruggiero, Peter, Kaminsky, G.M., Gelfenbaum, Guy, and Voigt, Brian, 2005, Seasonal to interannual morphodynamics along a high-energy dissipative littoral cell: Journal of Coastal Research, v. 21, no. 3, p. 553-578.

Ruggiero, Peter, Komar, P.D., and Allan, J.C., 2010, Increasing wave heights and extreme-value projections-The wave climate of the U.S. Pacific Northwest: Coastal Engineering, v. 57 , no. 5 , p. 539-552.

Ruggiero, Peter, Komar, P.D., McDougal, W.G., Marra, J.J., and Beach, R.A., 2001, Wave runup, extreme water levels and the erosion of properties backing beaches: Journal of Coastal Research, v. 17, no. 2, p. 407-419.

Sallenger, A.H., Jr., 2000, Storm impact scale for barrier islands: Journal of Coastal Research, v. 16, no. 3, p. 890-895.

Sallenger, A.H., Jr., Krabill, W.B., Swift, R.N., Brock, J., List, J., Hansen, Mark, Holman, R.A., Manizade, S., Sonntag, J., Meredith, A., Morgan, K., Yunkel, J.K., Frederick, E.B., and Stockdon, H., 2003, Evaluation of airborne topographic lidar for quantifying beach changes: Journal of Coastal Research, v. 19, no. 1, p. 125-133. 
Satake, Kenji, Wang, Kelin, and Atwater, B.F., 2003, Fault slip and seismic moment of the 1700 Cascadia earthquake inferred from Japanese tsunami descriptions: Journal of Geophysical Research: Solid Earth, v. 108, no. B11, p. 2535,17 p.

Seabloom, E.W., and Wiedemann, A.M., 1994, Distribution and effects of Ammophila breviligulata Fern. (American beachgrass) on the foredunes of the Washington coast: Journal of Coastal Research, v. 10, no. 1, p. 178-188.

Seymour, R.J., 2011, Evidence for changes to the northeast Pacific wave climate: Journal of Coastal Research, v. 27, no. 1, p. 194-201.

Seymour, Richard, 1996, Wave climate variability in southern California: Journal of Waterway, Port, Coastal, and Ocean Engineering, v. 122, July-August, p. 182-186.

Shalowitz, A.L., 1964, Shore and sea boundaries: Washington, D.C., U.S. Department of Commerce Publication 10-1, $749 \mathrm{p}$.

Sherwood, C.R., Jay, D.A., Harvey, R.B., Hamilton, Peter, and Simenstad, C.A., 1990, Historical changes in the Columbia River estuary: Progress in Oceanography, v. 25, nos. 1-4, p. 299-352.

Stauble, D.K., and Brumbaugh, R.W., 2003, An assessment of the nation's shorelines, USA: Shore and Beach, v. 71, no. 3, p. 11-18.

Stockdon, H.F., Holman, R.A., Howd, P.A., and Sallenger, A.H., Jr., 2006, Empirical parameterization of setup, swash, and runup: Coastal Engineering, v. 53, no.7, p. 573-588.

Stockdon, H.F., Sallenger, A.H., Jr., List, J.H., and Holman, R.A., 2002, Estimation of shoreline position and change using airborne topographic lidar data: Journal of Coastal Research, v. 18, no. 3, p. 502-513.

Taylor, J.R., 1997, An introduction to error analysis-The study of uncertainties in physical measurement ( $2 \mathrm{~d}$ ed.): Sausalito, Calif., University Science Books, 327 p.

Terich, T.A., and Komar, P.D., 1974, Bayocean spit-History of development and erosional destruction: Shore and Beach, v. 42 , no. 2 , p. $3-10$.

Terich, Thomas, and Levenseller, Terrance, 1986, The severe erosion of Cape Shoalwater, Washington: Journal of Coastal Research, v. 2, no. 4, p. 465-477.

Thieler, E.R., and Danforth, W.W., 1994, Historical shoreline mapping (I) - Improving techniques and reducing positioning errors: Journal of Coastal Research, v. 10, no. 3, p. 549-563.

Thieler, E.R., Himmelstoss, E.A., Zichichi, J.L., and Ergul, Ayhan, 2009, The digital shoreline analysis system (DSAS) version 4.0-An ArcGIS extension for calculating shoreline change: U.S. Geological Survey Open-File Report 20081278, accessed June 14, 2013, at http://woodshole.er.usgs. gov/project-pages/dsas/version4/.
U.S. Army Corps of Engineers, 1971, National shoreline study, California regional inventory: San Francisco, Calif., U.S. Army Corps of Engineers, 106 p.

U.S. Army Corps of Engineers, 2009, MCR dredged material disposal site annual use plan for 2009: U.S. Army Corps of Engineers and U.S. Environmental Protection Agency, 71 p.

Venkatarathnam, K., and McManus, D.A., 1973, Origin and distribution of sands and gravels on the northern continental shelf off Washington: Journal of Sedimentary Petrology, v. 43 , no. 3, p. 799-811.

Weber, K.M., List, J.H., and Morgan, K L.M., 2005, An operational mean high water datum for determination of shoreline position from topographic lidar data: U.S. Geological Survey Open-File Report 2005-1027, accessed June 14, 2013, at http://pubs.usgs.gov/of/2005/1027/ index.html.

Wiedemann, A.M., and Pickart, A.J., 2004, Temperate zone coastal dunes, chap. 4 of Martínez, M.L., and Psuty, N.P., eds., Coastal dunes-Ecology and conservation: Berlin, Springer-Verlag, v. 171, p. 53-65.

Witter, R.C., Kelsey, H.M., and Hemphill-Haley, Eileen, 2003, Great Cascadia earthquakes and tsunamis of the past 6700 years, Coquille River estuary, southern coastal Oregon: Geological Society of America Bulletin, v. 115, no. 10, p. 1289-1306.

Woxell, L.K., 1998, Prehistoric beach accretion rates and long-term response to sediment depletion in the Columbia River littoral system, USA: Portland, Oreg., Portland State University Master's thesis, 206 p.

Wright, L.D., and Short, A.D., 1983, Morphodynamics of beaches and surf zones in Australia, in Komar, P.D., ed., CRC handbook of Coastal Processes and Erosion: Boca Raton, Fla., CRC Press, p. 35-64.

Yin, J.H., 2005, A consistent poleward shift of the storm tracks in simulations of 21st century climate: Geophysical Research Letters, v. 32, no. 18, L18701, 4 p.

Young, I.R., Ziegler, S., and Babanin, A.V., 2011, Global trends in wind speed and wave height: Science, v. 332, no. 6028, p. 451-455.

Zarnetske, P.L., Hacker, S.D., Seabloom, E.W, Ruggiero, Peter, Killian, J.R., Maddux, T.B., and Cox, Daniel, 2012, Biophysical feedback mediates effects of invasive grasses on coastal dune shape: Ecology, v. 93, no. 6, p. 1439-1450.

Zarnetske, P.L., Seabloom, E.W., and Hacker, S.D., 2010, Non-target effects of invasive species managementBeachgrass, birds, and bulldozers in coastal dunes: Ecosphere, v. 1, no. 5, p. 1-20. 
This page has been left blank intentionally. 
Prepared by the Pembroke Publishing Service Center.

For more information concerning this report, contact:

Director

U.S. Geological Survey

Woods Hole Coastal and Marine Science Center

384 Woods Hole Road

Quissett Campus

Woods Hole, MA 02543-1598

or visit our Web site at:

http://woodshole.er.usgs.gov/ 


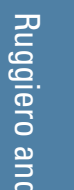

亭

$\stackrel{\underline{w}}{T}$

要

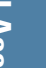

(1)

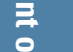

$\frac{\vec{c}}{0}$

क्户े

高

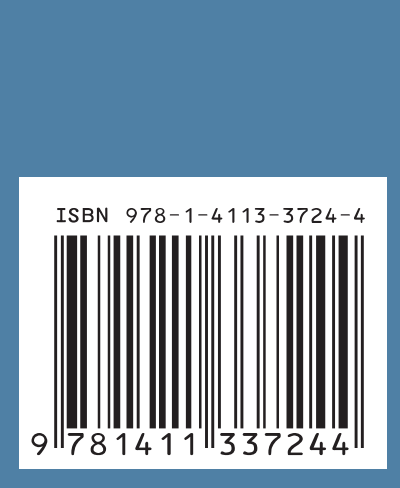

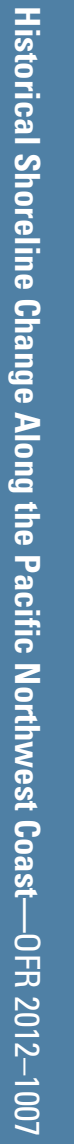
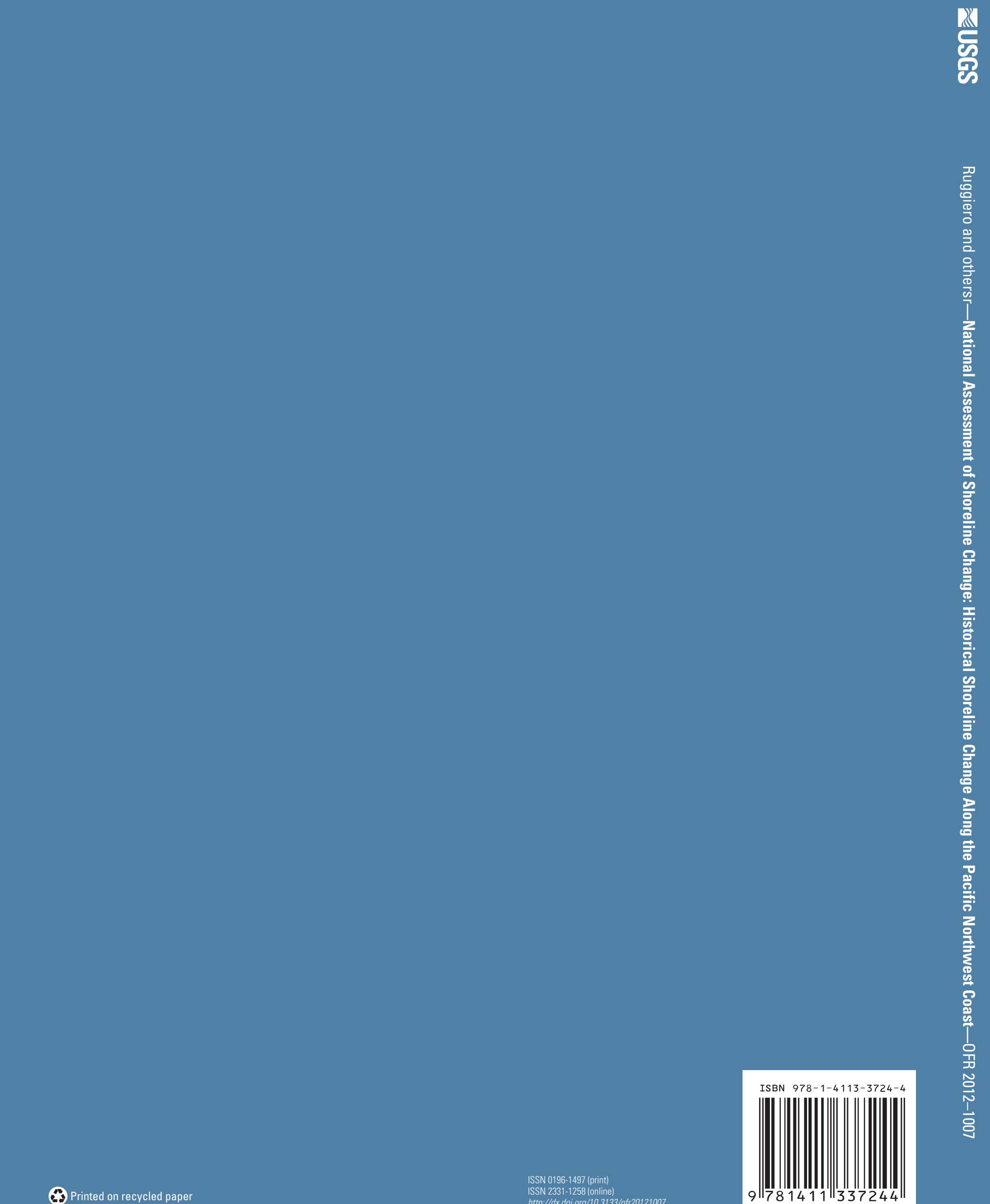